\title{
Trade and Thy Neighbor's War
}

\author{
Mahvash Saeed Qureshi
}




\title{
IMF Working Paper
}

\author{
Research Department
}

Trade and Thy Neighbor's War ${ }^{\dagger}$

Prepared by Mahvash Saeed Qureshi

Authorized for distribution by Atish Ghosh

December 2009

\begin{abstract}
This Working Paper should not be reported as representing the views of the IMF. The views expressed in this Working Paper are those of the author(s) and do not necessarily represent those of the IMF or IMF policy. Working Papers describe research in progress by the author(s) and are published to elicit comments and to further debate.

This paper examines the spatial dispersion effects of regional conflicts, defined as internal or external armed conflicts in contiguous states, on international trade. Our empirical findingsbased on different measures of conflict constructed using alternate definitions of contiguity and conflict — reveal a significant collateral damage in terms of foregone trade as a result of spillovers from conflict in neighboring countries. The magnitude of this negative externality is somewhat larger for international conflicts than intrastate warfare, but about one-third of conflict in the host economies. Further, the impact is persistent - on average, it takes bilateral trade three years to recover from the end of intrastate conflicts in neighboring states, and five years from international conflicts. These findings are robust to alternate definitions of conflict, estimation methods, and specifications, and underscore the importance of taking into account spillover effects when estimating the economic costs of warfare.
\end{abstract}

JEL Classification Numbers: F10, F51

Keywords: international trade, conflict, contiguous states

Author's E-Mail Address: mqureshi@imf.org

\footnotetext{
${ }^{\dagger}$ I am grateful to Tony Addison, Brock Blomberg, Quy-Toan Do, Olaf de Groot, Gregory Hess, Antonio Spilimbergo, Charalambos Tsangarides, and Thierry Verdier for very helpful comments and suggestions. The usual disclaimer applies.
} 


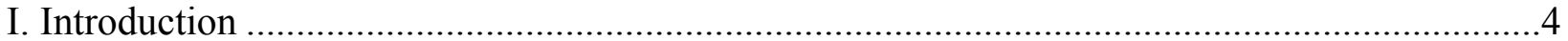

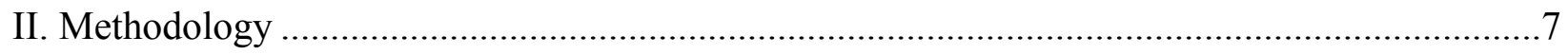

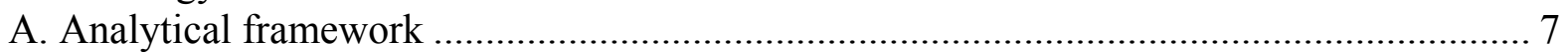

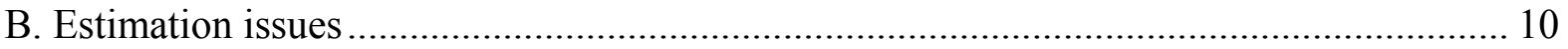

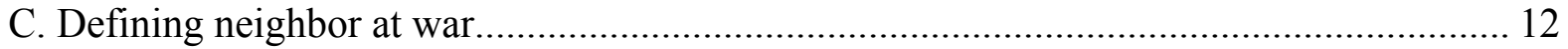

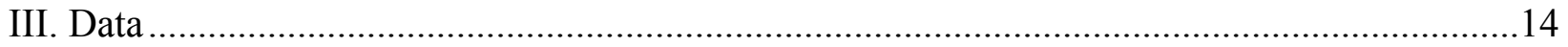

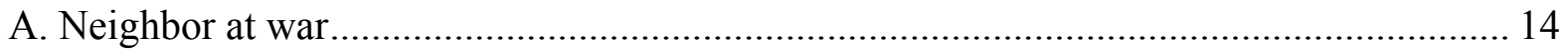

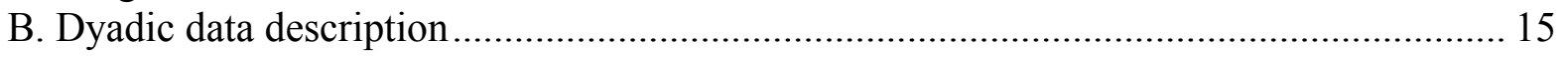

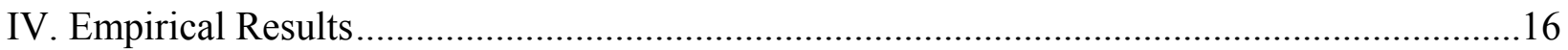

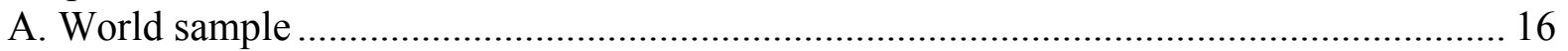

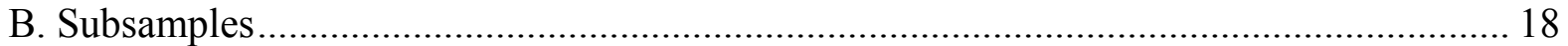

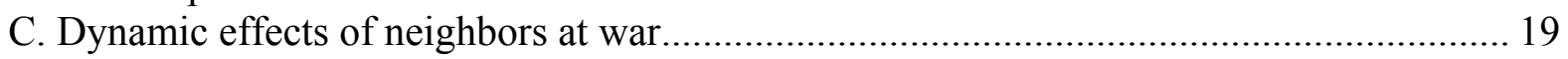

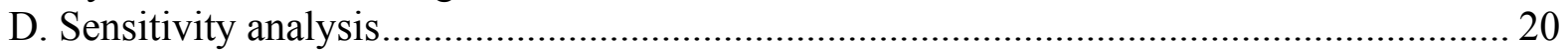

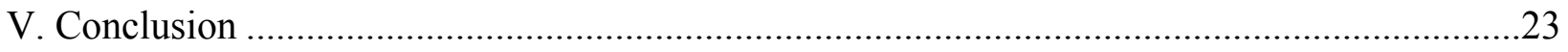

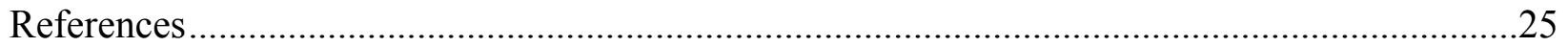

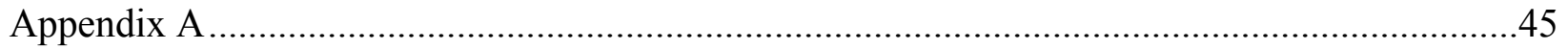

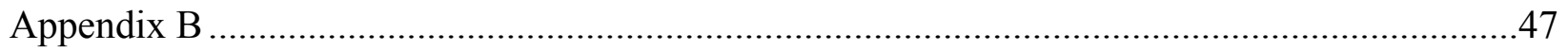

Tables

Table 1. Correlation between domestic and regional conflicts, 1948-2006 ............................. 28

Table 2. Distribution of societal and international conflict in neighbors, 1948-2006 ................. 28

Table 3. Estimation results for conflict presence, world sample (1948-2006) ............................ 29

Table 4. Estimation results for conflict intensity, world sample (1948-2006)............................. 30

Table 5. Estimation results for border weighted conflict, world sample (1948-2006) ................. 31

Table 6. Estimation results for conflict presence, subsamples (1948-2006)................................ 32

Table 7. Estimation results for conflict intensity, subsamples (1948-2006) ............................... 33

Table 8. Estimation results for border weighted conflict presence, subsamples (1948-2006).... 34

Table 9. Estimation results for border weighted conflict intensity, subsamples (1948-2006).... 35

Table 10. Estimation results for regional conflict duration, 1948-2006 ...................................... 36

Table 11. Persistence in regional warfare effects, world sample (1948-2006) ………………..... 37

Table 12. Persistence in regional warfare effects, subsamples (1948-2006) …………................. 38

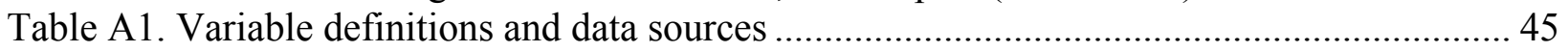

Table A2. Summary statistics of selected variables for dyadic data................................................ 46

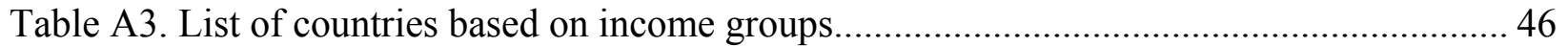

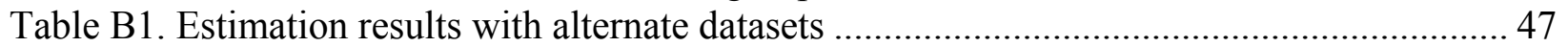

Table B2. Estimation results with alternate proxies, 1948-2006 ………................................... 48

Table B3. Estimation results with alternate specifications, 1948-2006 …………...................... 49

Table B4. Estimation results with IV approach, 1948-2006 ………………………............... 50

Table B5. Estimation results for different regions, 1948-2006 .................................................. 51 


\section{Figures}

Figure 1. Conflict in neighboring countries, 1948-2006 ............................................... 39

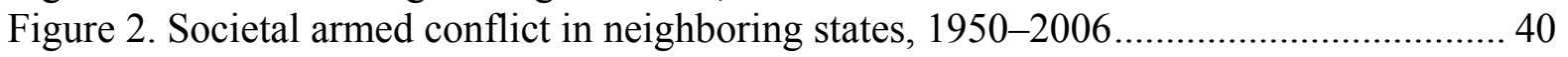

Figure 3. International armed conflict in neighboring states, 1950-2006 ........................ 41

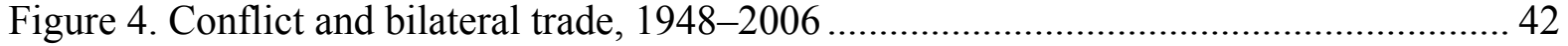

Figure 5. Regional conflict and trade, 1950-2006........................................................ 43

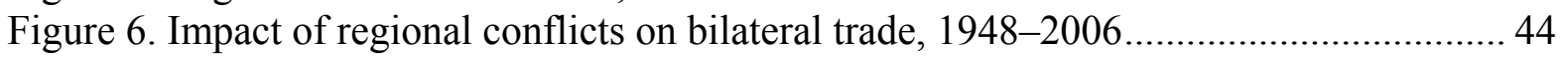




\section{INTRODUCTION}

"All wars are follies, very expensive and very mischievous ones." - Benjamin Franklin, 1783.

Political violence and war-both internal and international-have plagued the world for long. The incidence of international conflicts exhibits a declining trend in recent years, but interstate conflicts of different intensity, ideological origins, and dynamics have increasingly prevailed, particularly in less developed countries. In 2008, for example, there were 25 major conflicts raging in Africa, Asia, and other parts of the world, 20 of which represented interstate warfare. ${ }^{1}$ The economic costs of such conflicts resulting from physical and human capital losses, infrastructure destruction, lower investments, and market disruption are substantial, leading some scholars to call regional conflicts as "the greatest risk to the world today". ${ }^{2}$

From a global perspective, the challenges posed by conflicts are compounded further because seldom are their negative impacts confined within the national boundaries. In fact, the few existing studies investigating the economic consequences of spatial diffusion of conflicts, notably, Murdoch and Sandler $(2002,2004)$ and Collier and Hoeffler (2004), find evidence of profound negative spillover effects of intrastate conflict on the economic growth rates of neighboring states. ${ }^{3}$ The effect is strong in both the short and long runs, and large in cumulative terms - estimated to cost a typical neighbor about 43 percent of initial GDP (Collier and Hoeffler, 2004).

The pertinent question therefore is how do such large spatial effects set in? A variety of possibilities exist, at least theoretically, but empirical evidence does not support the direct spillover effects from migration, human capital dilution or a decline in long term investment ratios. ${ }^{4}$ In this paper, we investigate another potential but unexplored channel through which conflict in neighboring countries could have important consequences for economic growth: the reduction in international trade. Warfare in neighboring states could disrupt trade flows directly through, for example, a rise in transport costs, or, an interruption of input supplies and exports, if borders are hardened due to security concerns and external trade routes are damaged or blocked. There could also be indirect effects if the poor security situation and uncertainty surrounding the spreading out of the conflict deters traders from demanding the products originating in the

\footnotetext{
${ }^{1}$ Source: Marshall (2009).

2 Jeffrey Sachs's speech at the World Association of Investment Promotion Agencies conference, Geneva, 2002 (source: http://www.unctad.org/Templates/Webflyer.asp?docID=2469\&intItemID=2068\&lang=1). Also, a poll of economists conducted in 2005 by the Global Markets Institute at Goldman Sachs identified regional geopolitical conflicts as one of the top five risks to the global economy.

${ }^{3}$ The vast majority of studies on the economic consequences of conflicts and political disruptions investigate the effects on host economy's growth performance (see, for example, Barro, 1991; Alesina and Perotti, 1993; Collier, 1999; Abadie and Gardeazabal, 2003; and Blomberg, Hess, and Orphanides, 2004). The idea of negative spillovers from "bad" and conflict-ridden neighbors has mostly been explored in relation to its socio-political consequences (see, for example, Sambanis, 2001; and Fearon and Laitin, 2003).

${ }^{4}$ See, for example, Murdoch and Sandler (2004).
} 
region, and investors from making productive investments - thereby reducing trade and restricting growth of the tradable sector. ${ }^{5}$

The available anecdotal evidence supports these conjectures. For example, Malawi-a landlocked country in sub-Saharan Africa-had to rechannel its trade through South Africa when civil unrest erupted in neighboring Mozambique in the 1980s. Transport costs from Burundi to the nearest ports in Kenya and Tanzania were high during the war between Uganda and Tanzania in the late 1970s and early 1980s, while passage through conflict zones was unreliable and trade flows were frequently disrupted (World Bank, 1992). Similarly, the war in Azerbaijan at the end of 1980s interfered with the oil deliveries from the Caspian sea, and the wars in Afghanistan and Tajikistan disrupted central Asia's trade flows (Brown, 1996). More recently, the war in Iraq was accompanied by a reduction in total trade (in real terms) of neighboring Syria by 10 percent in $2003 .{ }^{6}$ A better understanding of the implications of warfare, not only on host economy's trade but also on its neighbors', is therefore essential to assess the devastating economic effects of conflicts and prepare an adequate response at both the national and international levels.

This paper attempts to systematically investigate the spatial dispersion of warfare consequences on international trade flows by addressing three key questions. First, are bilateral trade flows directly affected by conflict in contiguous states. Second, do countries successfully insulate themselves from neighborhood warfare as it continues over time. Third, are regional warfare effects persistent in nature. To address these questions, we develop a simple theoretical framework of bilateral trade flows that explicitly incorporates the effect of neighborhood conflict through both demand and supply side mechanisms, and motivates the empirical analysis. On the demand side, foreign consumers differentiate between products by country of origin - expressing ideological and political preferences for products from nonconflict regions. On the supply side, regional conflict increases trade costs, affecting exporter competitiveness and reducing trade. The derived reduced form equation specifies a causal relationship, predicting that conflict in contiguous states depresses bilateral trade. ${ }^{7}$

Our empirical assessment is based on an extended armed conflict dataset that covers 145 countries over the period 1948-2006. Using this dataset, we construct several composite measures - with alternate definitions of contiguity - to reflect internal and international conflict presence and intensity in the immediate region. Our wide range of measures for regional conflict reveal interesting spatial and temporal trends. First, we find that while the prevalence and intensity of international conflicts in neighboring states has declined over the sample period, intrastate conflicts have become more widespread and increased in intensity. Second, regional

\footnotetext{
${ }^{5}$ Conflict could also spillover to neighboring states, and reduce trade as a result of conflict in the host economy. However, we are purely interested in the direct trade effect of conflicts in neighboring states and, hence, control for the effects emanating from conflicts in the host economies.

${ }^{6}$ Source: IMF's World Economic Outlook database.

${ }^{7}$ While both the demand and supply side channels may be at play if the conflict is taking place within the neighboring territory, a reduction in demand is possible even if the neighboring state is engaged in a war in another geographical region (for example, if the importing country believes that the trading partner is politically or economically involved with its neighbor in that war).
} 
conflict is the most prevalent in Africa and parts of Asia-for example, no country in South Asia and only a handful in Africa had no neighbor involved in some form of conflict in 2006. Furthermore, the correlation between self-involvement in warfare and regional conflicts is low, indicating that the economic costs of warfare are unlikely to be fully accounted for by studying domestic conflict only.

The results from our empirical estimations provide strong evidence of systemic effects of regional conflicts. Specifically, while controlling for conflict in the host economies as well as for other regional characteristics, we find that conflict in neighboring states has a significant but modest adverse effect on bilateral trade flows. The magnitude of this effect is somewhat larger for international wars as compared to intrastate wars, and about one-third of that for host country conflict. For example, bilateral trade flows are estimated to be, on average, about 12 percent lower if at least one of the trading partners is involved in a conflict, but the estimated change as a result of an additional intrastate and international conflict in the dyad's neighborhood is about 24 percent. An increase in the measure of regional conflict intensity also imposes higher trade costs - for example, a shock of one standard deviation to the measures of intrastate and international conflicts reduces bilateral trade by about 7 and 3 percent, respectively.

The results for different subsamples based on income classification show that the negative impact is significant for both high and low income countries, and relatively more pronounced for their trade with each other. In addition, regional warfare effects appear to be dynamic in natureincreasing with the duration of the conflict, and, on average, persisting for 3-5 years after its end. The post-regional conflict trade recovery period is, however, shorter (between 2-4 years) for high income countries. These results are robust to alternate datasets, proxies of conflicts, estimation methods, and model specifications.

This paper, to our best knowledge, is the first to analyze the spatial dimensions of conflicts for international trade. ${ }^{8}$ In doing so, it combines two strands of literature-regional contagion and spillover effects, and the nexus between international trade and conflict. The first body of literature has mostly focused on financial contagion across regions, and spillovers of technology and knowledge in the economics domain (see, for example, Claessens and Forbes, 2001; Holod and Reed, 2004), while studies in political science have been preoccupied with the likelihood of international spillovers of regional conflicts. Notable exceptions to this include Ades and Chua (1997), Murdoch and Sandler (2002, 2004), Collier and Hoeffler (2004), Chauvet, Collier and Hoeffler (2007), and De Groot (2009) who examine the spillover effects of neighborhood conflict and political instability on economic growth.

The second strand of literature — both in political science and more recently in economics — has been limited to analyzing the impact of conflict on bilateral trade when the host economy is itself involved in warfare, either with the trading partner or with another country. ${ }^{9}$ These studies

\footnotetext{
${ }^{8}$ A related but different set of studies examine the consequences of terrorism on bilateral trade (see, for example, Nitsh and Schumacher, 2004; Fratiani and Kang, 2004; and Mirza and Verdier, 2008). Within this literature, Mirza, Sousa, and Verdier (2009) study the impact of transnational terrorism diffusion on security and trade.

${ }^{9}$ Several studies, particularly in political science, have also been concerned with the reverse causation from trade to conflict (see, for example, Pollins, 1989; Mansfield and Bronson, 1997; and Barbieri, 2002).
} 
almost unanimously show significant and large adverse effects of self-involvement in conflict on trade. For example, Glick and Taylor (2004), study the effects of World Wars I and II when at least one country in the trading pair is engaged in war. They find strong contemporaneous and persistent negative effects of warfare on bilateral trade flows even after controlling for possible endogeneity. Similarly, Blomberg and Hess (2006) investigate the effects of different types of violence on bilateral trade. They find a significantly negative impact of external and internal conflict, as well as of terrorism, that is larger than the estimated tariff-equivalent costs of border and language barriers. Martin, Mayer, and Thoenig (2008) analyze the two-way relationship between military conflicts and trade. They show that military conflicts substantially reduce trade, while the probability of war escalation is lower for countries that engage in greater bilateral trade. Multilateral trade openness has the opposite effect in their model as it decreases bilateral trade dependence, and escalates the probability of bilateral war.

The rest of the paper is organized as follows. Section II develops the analytical framework, and describes the construction of composite measures to reflect neighborhood conflict. Section III discusses the data. Section IV presents the empirical results and the sensitivity analysis. Section V concludes.

\section{Methodology}

\section{A. Analytical framework}

To examine the impact of conflict in contiguous states on trade, we develop a simple theoretical framework that augments the traditional gravity model of bilateral trade flows. Existing research tends to postulate the impact of conflict on international goods flows from the supply side onlyspecifically, by assuming an increase in trading costs. We introduce both demand and supply side mechanisms through which regional warfare could affect trade by: (i) the explicit modeling of Armington's (1969) assumption that consumers differentiate between products based on the country of origin, expressing preferences for products originating from nonconflict regions; and (ii) a rise in trade costs as security is increased on the borders and external trade routes are blocked or damaged, which affects the supply of exports.

Consider a world economy with $i=1, \ldots, N$ countries, where each country specializes in the production of one good and all goods are differentiated by the country of origin. Consumers in country $j$ have identical and homothetic preferences, approximated by a constant elasticity of substitution (CES) utility function, given by

$$
U_{j}=\sum_{i=1}^{N}\left(b_{i j} c_{i j}\right)^{\frac{\sigma-1}{\sigma}},
$$

where $c_{i j}$ is the consumption in country $j$ of the good imported from country $i, \sigma$ is the elasticity of substitution between goods $(\sigma>1)$, and $b_{i j}$ reflects the (relative) evaluation or preference of the consumers in country $j$ of the good imported from country $i$. As hypothesized by Pollins (1989), we assume that consumers in country $j$ employ a common logic, which incorporates both economic as well as socio-political and ideological concerns into their import decisions. In some cases, these concerns may be revealed by straightforward boycotts or import bans-such as that in the context of "conflict diamonds" originating from central and western Africa-while in others, they may reflect a general foreign policy orientation and purposeful attempt to exert 
pressure on the exporter to change the status quo by manipulation of economic ties. The exporter in question could itself be directly involved in the conflict or perceived to be politically or economically involved in a neighboring conflict. The foreign consumers therefore have a preference for goods originating from nonconflict regions such that

$b_{i j}=\exp \left(\beta_{1}\right.$ War $\left._{i}+\beta_{2} N w a r_{i}\right)$,

where $\mathrm{War}_{i}$ and $\mathrm{Nwar}_{i}$ - assumed to lie within a continuous range [0,, - denote the status of conflict in country $i$ and its neighborhood, respectively, and $\beta_{1}$ and $\beta_{2}$ are (negative) parameters that reflect the responsiveness of consumers' preferences to the degree of conflict in country $i$ and its neighborhood, respectively. A value of zero for $W r_{i}$ and $N w a r_{i}$ indicates peace while strictly positive values indicate conflict, so that $b_{i j}$ approaches one for peace and zero for a high level of conflict. ${ }^{10}$ Hence, the aggregate utility function of country $j$ is strictly decreasing with the warfare exposure of exporter $i$.

The representative consumer in country $j$ maximizes the utility function subject to the following budget constraint

$$
Y_{j}=\sum_{i=1}^{N} p_{i j} c_{i j}
$$

where $Y_{j}$ is the aggregate income of all consumers in country $j$, and $p_{i j}$ is the exported product's price in country $j$. The demand for each product $c_{i j}$, derived from maximizing (1) subject to (3), is given by

$$
c_{i j}=b_{i j}^{\sigma-1}\left(\frac{p^{i j}}{P^{j}}\right)^{-\sigma} \frac{Y_{j}}{P^{j}},
$$

where $P_{j}$ is the consumer price index of country $j$, defined as

$$
P_{j}=\sum_{i=1}^{N}\left(b_{i j}^{\sigma-1} p_{i j}^{1-\sigma}\right)^{1 / 1-\sigma} .
$$

From (4), we can see that the demand for country $i$ 's good is an increasing (decreasing) function of peace (conflict) in country $i$ and its neighborhood. The total nominal value of exports, $X$, from country $i$ to $j$ can hence be written as

$$
X_{i j}=p_{i j} c_{i j}=b_{i j}^{\sigma-1}\left(\frac{p_{i j}}{P_{j}}\right)^{1-\sigma} Y_{j},
$$

where the first equality holds by definition, and the second is obtained from (4).

We now assume that prices between countries differ due to trade costs such that the price at destination is given by $p_{i j}=p_{i} T_{i j}$, where $p_{i}$ reflects net of transport (or free on board) domestic

\footnotetext{
${ }^{10}$ Following a somewhat similar approach, Reuveny and Kang (2003) model a reciprocal relationship of bilateral trade, conflict and peace between dyads based on the individual actions of importers, exporters, and governments.
} 
prices, and $T_{i j}$ represents "iceberg trade costs". ${ }^{11}$ In general, $T_{i j}$ is considered to include all factors that limit trade between $i$ and $j$, and is expressed as a function of natural trade costs $(D)$, for example, distance, common border, and access to sea, and artificial trade costs $(\tau)$, for example, tariffs, institutional quality, infrastructure, and currency conversion costs. That is,

$$
T_{i j}=D_{i j} \exp \left(\tau_{i j}\right) \text {. }
$$

Substituting (7) in (6), total exports can be expressed as

$$
X_{i j}=p_{i j} c_{i j}=b_{i j}^{\sigma-1}\left(\frac{p_{i j}}{P_{j}}\right)^{1-\sigma} Y_{j}=b_{i j}^{\sigma-1}\left(\frac{p_{i} T_{i j}}{P_{j}}\right)^{1-\sigma} Y_{j} .
$$

If conflict erupts in the neighborhood of country $i$, then from (7) the resultant tightening of security at the borders, or any blockages and damage to the external trading routes, would manifest as a rise in $\tau$ and $T_{i j}$, which for a given preference parameter $b_{i j}$ would imply lower export supply.

Following Anderson and van Wincoop (2003), we can simplify (8) by assuming symmetric transportation costs $\left(T_{i j}=T_{j i}\right)$, and making use of the market clearing condition given by ${ }^{12}$

$$
y_{i}=\sum_{j=1}^{N} c_{i j} T_{i j} .
$$

Multiplying both sides of (9) by $p_{i}$ and using $p_{i j}=p_{i} T_{i j}$, we have

$$
p_{i} y_{i}=\sum_{j=1}^{N}\left(\frac{p_{i} T_{i j}}{P_{j}}\right)^{1-\sigma} b_{i j}^{\sigma-1} Y_{j} .
$$

Further, denoting country $i$ 's aggregate output by $Y_{i}=p_{i} y_{i}$, world output by $Y_{w}$, and country $i$ 's share in world output by $s^{i}=Y^{i} / Y^{w}$, we obtain from (10)

$$
\tilde{p}_{i}=\frac{s_{i}^{1 / 1-\sigma}}{\tilde{P}_{i}},
$$

where $\widetilde{P}_{i}=\left(\sum_{j=1}^{N} s_{j} b_{i j}^{\sigma-1}\left(\frac{T_{i j}}{P_{j}}\right)^{1-\sigma}\right)^{1 / 1-\sigma}$.

Substituting (12) into (5) and (8), we obtain

$$
X_{i j}=\frac{Y_{i} Y_{j}}{Y_{w}} b_{i j}^{\sigma-1}\left(\frac{T_{i j}}{\widetilde{P}_{i} \widetilde{P}_{j}}\right)^{1-\sigma},
$$

\footnotetext{
11 "Iceberg trade costs" imply that country $i$ needs to ship $T_{i j} \geq 1$ units of the product in order to have one unit of the product reach country $j$

${ }^{12}$ Equation (9) follows from the assumption of iceberg transport costs, which implies that the output of the firm exceeds the amount received by the consumer.
} 
where $\widetilde{P}_{j}=\left(\sum_{i=1}^{N} s_{i} b_{i j}^{\sigma-1}\left(\frac{T_{i j}}{\widetilde{P}_{i}}\right)^{1-\sigma}\right)^{1 / 1-\sigma}$.

Equation (13) is the familiar gravity model, whereby bilateral trade between countries depends on their outputs, trade costs, and the implicit price measures or "multilateral resistance" terms $P_{i}$ and $P_{j}$. In addition, the model includes the term, $b_{i j}$, that reflects consumers' political preference for trading partners. Taking logs of equation (13) and adding scripts for the time dimension, we obtain the following equation for estimation purposes

$$
\begin{aligned}
& \log \left(X_{i j t}\right)=\beta_{0}+\beta_{1} \text { War }_{i t}+\beta_{2} N w a r_{i t}+\beta_{3} \log \left(Y_{i t} Y_{j t}\right)+\beta_{4} \log \left(D_{i j}\right)+\beta_{5} \tau_{i j}-\log \left(P_{i t}\right)^{\sigma-1} \\
& -\log \left(P_{j t}\right)^{\sigma-1}+\mu_{i j t} .
\end{aligned}
$$

Equation (14) gives us the impact of regional warfare on bilateral trade through both the supply $(\tau)$ and demand (Nwar) sides. However, relevant data on changes in transport costs as a result of regional conflict that would allow us to separately identify the effect of $\tau$ is not available. Hence, in the estimated model, the coefficient for Nwar captures both the demand as well as supply side effects of conflicts in neighboring states - and is expected to be negative-while $\tau$ includes other variables typically used to proxy artificial trading costs such as currency union, free trade agreements, common language, and historical ties.

\section{B. Estimation issues}

An important issue in estimating equation (14) is that of measuring the unobserved multilateral price terms. ${ }^{13}$ Including them in the error term and estimating the model with the pooled Ordinary Least Squares (OLS) approach could lead to a serious omitted variables bias problem, originating from the correlation of these terms with any of the right-hand side variables.

Research following Rose (2000) attempts to control for this bias by introducing country-specific idiosyncrasies (or country fixed-effects (CFE)) in the gravity model — both for cross-sectional and panel estimations. However, given that there is a time-series element to the potential bias that is not eliminated with this procedure; Anderson and van Wincoop (2004) propose that separate country fixed-effects should be included for each year (CYFE) to take into account changes in multilateral resistance over time.

Glick and Rose (2002) argue that including the CFE or CYFE may still not resolve the omitted variables problem. This is because the unobserved variables could be correlated with the bilateral characteristics of the dyads, which may bias the CFE/CYFE estimates. They therefore propose using the panel data fixed-effects estimator that adds country-pair specific effects (CPFE) to the gravity equation, thereby controlling for any strong bilateral likelihood to trade. In a recent paper, Baier and Bergstand (2007) note that in a panel setting, the multilateral price variables $\left(P^{\mathrm{i}}\right.$ and $P^{\mathrm{j}}$ ) are likely to be time varying. Thus, controlling for them through CPFE may not fully account for the omitted variable problem. They therefore propose including both the CPFE as

\footnotetext{
${ }^{13}$ Anderson and van Wincoop (2003) propose an iterative method that requires custom programming to estimate $P_{i}$ and $P_{j}$. Since the process is complex, they also propose an alternative method suitable for empirical work, which is to introduce coefficients of origin and destination fixed effects.
} 
well as the CYFE to control for possible correlation between the unobserved omitted and time invariant bilateral variables, and between the omitted and time varying variables, respectively. We denote this estimation approach as country-year and county-pair fixed effects (CYPFE).

As discussed later in Section IV, our estimation results for equation (14) are broadly similar for both the CPFE and CYPFE approaches when we use the world sample. Considering the large $N$ and $T$ dimensions of our dataset, and the associated computational difficulties in estimating CYPFE, we retain the CPFE as our preferred estimation approach for other specifications involving, for example, different subsamples. The final estimating equation therefore takes the form

$$
\begin{aligned}
& \log \left(X_{i j t}\right)=\beta_{0}+\beta_{1} \text { War }_{i t}+\beta_{2} N w a r_{i t}+\beta_{3} \log \left(Y_{i t} Y_{j t}\right)+\beta_{4} \log \left(D_{i j}\right)+\beta_{5} \tau_{i j}+\sum_{k=6}^{K} \beta_{k} Z_{k, j i t} \\
& +u_{i t}+\lambda_{t}+\mu_{i j t},
\end{aligned}
$$

where $Z$ is a vector consisting of $k$ control variables that reflect regional characteristics such as the (median) regional polity score and real income per capita; $u_{i j}$ reflect the country-pair specific effects, $\lambda_{t}$ are time-specific factors common across all countries, and $\mu_{i j t}$ is the normally distributed error term. The reason for taking into account other neighborhood features in the model is to ensure that our regional conflict variable does not capture spillovers from other potential socio-economic channels.

In addition to the omitted variable bias issue, a potential estimation concern that has preoccupied researchers investigating the effect of the host economy's conflict on trade is to address the possible reverse causality from trade to conflict. Two hypothesis have been postulated on this front: the first argues that trade between two countries reduces the likelihood of a conflict between them (see, for example, Polachek, 1992; and Oneal and Russett 1999), while in the second view, trade causes conflict as countries compete over economic and political goals (for example, Gasiorowski, 1986; Gowa 1994; and Barbeiri, 2002).

Endogeneity concerns are, however, mitigated in equation (15) as our main variable of interest is warfare in dyad's neighboring countries. From a theoretical point of view, it is easier to believe in the exogeneity of regional conflicts in bilateral trade models since trade between $i$ and $j$ is unlikely to affect interstate conflict in their neighboring states. As for international conflicts in the region, trade may have an effect to the extent that both $i$ and $j$ are neighbors, in which case, as hypothesized in the political science literature, their bilateral trade could affect the probability of going to war with each other. Although, even then, the impact of bilateral trade on the regional conflict variable is likely to be small in our case as the latter variable includes international conflict involvement of all neighboring states (and not only of the neighboring country $j$ ).

Similar argument holds for our variable depicting conflict within the trading pair — as the measure includes all types of interstate and international conflict that a pair is involved inwhich is unlikely to be strongly affected by their bilateral trade. Nevertheless, we address any endogeneity concerns that may arise for this variable through the inclusion of CPFE and time effects; and by applying the instrumental variable (IV) methodology discussed in the sensitivity analysis. 


\section{Defining neighbor at war}

The most important issue in the estimation of equation (15) is to measure conflict in the host and neighboring economies in an appropriate way. The definition and measurement of armed conflict is a subject of ongoing debate in political science literature, which has led to a proliferation of conflict datasets in recent years. Differences among datasets exist in the type of event coded, the spatial and temporal dimensions, the violence threshold for event inclusion, the timing and duration of the conflict, and the treatment of interstate, intrastate and extra state wars. Some of the prominent conflict datasets often used in academic literature include those of the Correlates of War (COW) project, the Uppsala Conflict Data Program (UCDP), the Center for International Development and Conflict Management and the Center for Systematic Peace (CIDCM-CSP), Fearon and Laitin (2003), and Sambanis (2004). ${ }^{14}$

In this paper, we define conflict in a contiguous country using the Major Episodes of Political Violence (MEPV) dataset compiled by the CIDCM-CSP. ${ }^{15}$ The MEPV defines major armed conflicts as those episodes of political violence, which "involve at least 500 'directly-related' fatalities and reach a level of intensity in which political violence is both systematic and sustained (a base rate of 100 'directly-related deaths per annum')". There are three important advantages of using this dataset: first, it provides information on different types of armed conflict: (i) civil — intrastate involving rival political groups; (ii) ethnic — intrastate involving the state agent and a distinct ethnic group; and (iii) international-involving at least two states. ${ }^{16}$ Second, it assigns magnitude scores - ranging from 1 (lowest) to 10 (highest) - to each episode based on the scale of the conflict and the available estimates of fatalities. The scores are considered to be comparable across time, countries, and typologies of warfare, and provide readily usable information on the existence as well as the intensity of major armed conflicts. ${ }^{17}$ Finally, the dataset provides information on conflicts in a large number of countries - about 162 in recent years - over a long time horizon (1948-2006).

To construct our measures for warfare in neighboring countries, we use six different variables of conflict from the MEPV dataset - international violence (intviol), international war (intwar), civil violence (civviol), civil war (civwar), ethnic violence (ethviol), and ethnic war (ethwar) and proceed in two main steps. First, for each country-year observation, we create variables to indicate conflict intensity and presence. To this end, we combine the magnitude scores for the four measures of intrastate conflict - civviol, civwar, ethviol and ethwar - to reflect societal conflict intensity (civconf), and the two measures for extrastate conflict - intviol and intwar- to indicate international conflict intensity (intconf). We add these two measures to create a measure for overall conflict intensity (conflict), and then use the three composite measures-civconf, intconf, and conflict - to create binary variables that indicate conflict presence. Hence, the variables civconfd, intconfd, and conflictd take the value of one if the country experienced a civil

\footnotetext{
${ }^{14}$ See Sambanis (2004) for a comprehensive discussion on different conflict datasets.

${ }^{15}$ Source: Marshall (2009).

${ }^{16}$ It further differentiates whether each conflict episode constitutes violence or war. Violence refers to episodes of aggression without necessary exclusive goals, while war is defined as violence between distinct groups with the intent to impose a unilateral result to the contention.

${ }^{17}$ For a detailed explanation of the dataset and coding methodology, see Marshall (2009).
} 
war, international war, or any type of conflict, respectively, in the observation period, and zero otherwise.

Next, we combine these six conflict measures with the geographical contiguity data of Stinnett et al. (2002) to obtain measures for conflict presence and intensity in the neighborhood. ${ }^{18}$ While neighbors for a specific state could be defined on the basis of linguistic, religious, historical and economic linkages, our theoretical framework rests on the importance of geographical proximity for conflict externalities. In addition, using contiguous states to constitute the neighborhood prevents us from making any subjective judgment errors about what countries to include in a certain region. Thus, following Murdoch and Sandler (2004), we employ two definitions of neighboring states. The first simply defines countries as neighbors if they share a common border. The second builds on the first definition but takes into account the fact that the length of a common border may influence the extent of the spatial transmission of negative externalities from a neighbor's conflict. It therefore determines the geographical importance of each neighbor based on the length of their common border. ${ }^{19}$

Using the above definitions, we compute weighted averages of the warfare measures for the neighboring states. Specifically, based on the first definition which assigns equal weights to the $n$ contiguous states, our measures for neighborhood conflict presence and intensity for country $j$ $(j \neq i)$ in time period $t$ are, respectively, given by:

$$
\begin{aligned}
& \text { nward }_{j t}=\frac{1}{n} \sum_{i=1}^{n}\left(\operatorname{ward}_{i t}\right), \text { and } \\
& n w_{j t}=\frac{1}{n} \sum_{i=1}^{n}\left(\text { war }_{i t}\right),
\end{aligned}
$$

where war = civconf, intconf, and conflict.

With the second definition, which determines the weights of each neighbor by the length of the common border relative to the total length of country $j$ 's border, (16) and (17) are modified and given as

$$
\begin{aligned}
& w_{-} \text {nward }_{j t}=\sum_{i=1}^{n} \text { ward }_{i t} \times \frac{\left(\text { borderlength }_{i j t}\right.}{\text { totalborder }_{j t}}, \text { and } \\
& w_{-} n w a r_{j t}=\sum_{i=1}^{n} \text { war }_{i t} \times \frac{\left({\text { borderlength })_{i j t}}_{\text {totalborder }}\right.}{\text { tott }} .
\end{aligned}
$$

\footnotetext{
${ }^{18}$ Stinnett et al. (2002) identify contiguity between states in the international system during 1816-2006. Hence they consider any changes in international geographical boundaries that may have occurred over the sample period.

${ }^{19}$ In Stinnett et al.'s (2002) dataset, contiguous dyads are defined as those separated by: 1) a land or river border; 2) 12 miles of water or less; 3) 24 miles of water or less (but more than 12 miles); 4) 150 miles of water or less (but more than 24 miles); and 5) 400 miles of water or less (but more than 150 miles). For the first definition, we include contiguity relations of types 1 and 2 so islands are not dropped from the sample. However, for the second definition, we restrict the definition to direct land contiguity only, hence the estimated sample is smaller.
} 
Thus, (16)-(19) give us 12 different measures to describe neighborhood or regional conflict. As the magnitude scores assigned in the MEPV dataset range from 0 to 10 , all measures can only take nonnegative values by construction. ${ }^{20}$

\section{DATA}

\section{A. Neighbor at war}

The MEPV dataset documents 1,448 observations for some form of societal conflict, and 330 for major armed international conflict (excluding wars of independence) in about 160 countries for the period 1948-2006. Based on the first definition of contiguity, this gives us 3,589 and 1,070 country-year observations where one or more neighboring states was involved in societal and international conflict, respectively. ${ }^{21}$ Figure 1 summarizes this information and shows the percentage of countries with at least one neighbor involved in any type of conflict during 19482006. It also gives the maximum number of neighbors in conflict at a given point in time, and the distribution of countries according to the total duration of regional conflict. Clearly, the percentage of countries experiencing regional conflict increased sharply in the early 1980s, but declined toward the end of 1990s. ${ }^{22}$ For countries in the sample which had some form of conflict in a neighbor, about one-half endured it for a total of at least 20 years, and one-fourth for 40 years or more, suggesting a high degree of persistence (and recurrence) in regional conflicts.

Figures 2 and 3 present the neighborhood conflict intensities as measured by the ncivconf and nintconf measures, respectively, and the total number of neighboring countries involved in a conflict, at different points in time $\left(1950,1980\right.$, and 2006). ${ }^{23}$ The charts indicate that the prevalence of international warfare in neighboring states has declined since 1950, but armed intrastate conflicts in contiguous regions have increased - both in terms of intensity and the countries involved - particularly in Africa, the Middle East, and South Asia. For example, in 2006, the ten countries with the highest values for societal conflict (ncivconf) are in Africa and Asia; and the lowest in Europe.

It is also interesting to note that a large number of otherwise peaceful countries rank relatively high in terms of regional instability due to their geographical closeness to states with some form of conflict. For example, both Finland and Norway appear shaded in the maps due to their proximity with Russia. This observation is supported by Table 1, which shows that the correlation between the presence and intensity of domestic conflict - as measured by civconf, intconf, and conflict - and regional conflicts is low. Thus, in estimating the trade losses emerging from conflict, it may not be sufficient to study domestic warfare only as regional conflict may also have a role to play thereby providing additional information.

\footnotetext{
${ }^{20}$ The minimum possible value for all measures is zero, indicating no regional conflict. The maximum value for conflict presence measures is 1 , indicating conflict in all neighboring states, while that for conflict intensity measures is 60, indicating all types of inter and intrastate conflict of the highest intensity in the neighboring state(s).

${ }^{21}$ These constitute about 50 percent and 30 percent of the full country-year sample, respectively.

${ }^{22}$ The decline largely reflects the end of the first Russian-Chechen war, which ended in 1996.

${ }^{23}$ See Figure A1 for the trend in neighborhood magnitude scores for societal and international conflicts.
} 


\section{B. Dyadic data description}

The regional conflict data described above is in country-year form, which is converted to dyadyear format to correspond with the annual bilateral trade data obtained from the IMF's Direction of Trade Statistics used for estimation purposes. For each dyadic observation, neighborhood conflict is defined as the sum of the conflict measures for both trading partners. Data on other variables used in the analysis - which are also converted into dyadic form - such as real GDP (in 2000 US dollars), real GDP per capita (in 2000 US dollars), population and geographical size are compiled from the World Bank's World Development Indicators 2007. The polity index, scaled between -10 (lowest) and 10 (highest), has been obtained from the Polity IV Project. The source of information on geographical attributes including length of the borders, colonial ties, and language is the CIA World Factbook 2004 and Rose (2000), while currency unions and free trade agreements have been obtained from Tsangarides et al. (2008) and the Regional Trade Agreements database of the World Trade Organization, respectively. ${ }^{24}$

The estimated sample is an unbalanced panel dataset covering 145 countries over the period 1948-2006, yielding 9,024 individual country pairs (rather than $145 \times 144 / 2=10,440$ because of missing observations), and 199,912 observations. ${ }^{25}$ We estimate the gravity model for the world sample as well as for various subsamples to explore whether the role of trade and regional conflicts differs across subsets of countries. We do so by dividing the sample into two income groups - low and lower middle income (low); and upper middle and high income (high) — based on the World Bank's income classification, and subsequently report the results for four subsamples (world, high-high, high-low, and low-low). Specifically, the first subsample covers all countries for which the required data are available; the second comprises those observations where both trading partners belong to the high income group; the third includes dyads where one partner belongs to the high income and the other to the low income group; and the fourth constitutes those pairs where both countries are in the low income group. ${ }^{26}$

Table 2 gives the distribution of observations across the different subsamples. About 27 percent of the observations in the sample belong to the upper middle and high income group, but they represent about 80 percent of world trade conducted in the sample period. The low and lower middle income dyads constitute 20 percent of the sample but account for only a fraction of total trade. Trade conducted between high and low income groups is also almost one-fifth of the trade conducted between the high income countries. Conflict appears to be prevalent in the neighborhood of both high and low income dyads - but whereas 64 percent of the high income dyads had some form of societal conflict in the neighboring countries, this percentage is much higher (about 90 percent) for the low income dyads. The neighborhood societal conflict intensity measures of the low income trading pairs also appear to be twice as high as for the high income dyads. While the share of trade conducted between pairs with regional conflict is higher than

\footnotetext{
${ }^{24}$ For cases where borders have changed over the sample period (for example, Yugoslavia and Czechoslovakia), we use other archival sources to reconstruct geographical boundaries for computing border lengths. See Appendix A for a description of data sources and selected summary statistics.

${ }^{25}$ When the border weighted definition of contiguity is used that does not include any type of water contiguity, the total sample has 181,405 observations.

${ }^{26}$ See Appendix A for the list of countries grouped according to income classification.
} 
those without, this likely reflects the widespread existence of conflict rather than a proof of causality.

Figure 3 plots the (unconditional) relationship between regional conflict measures and (log of) bilateral trade for all dyads averaged over the sample period. The negative relationship between bilateral trade and the intrastate and overall conflict measures is apparent from the plots, but the relationship between international conflicts in neighbor states and trade appears positive from the fitted line. These plots are, however, impressionistic only as they do not take into account other factors that affect trade such as income and geographical attributes. In what follows, we control for the other determinants of trade to formally investigate its link with regional warfare.

\section{EMPIRICAL RESULTS}

\section{A. World sample}

The estimation results for equation (15) for the world sample are presented in Tables 3-5. We investigate the impact of conflict in the neighborhood on bilateral trade by sequentially including the measures for intrastate, international and overall conflict presence and intensity. For completeness and comparative purposes, we estimate the gravity model using all the estimators discussed earlier, namely, pooled OLS, CFE, CPFE, and CYPFE. ${ }^{27}$ As our dataset pools a large number of country pairs over almost 50 years, the error term is likely to exhibit correlation patterns for given country pairs. To take this into account, we cluster the robust standard errors at the country pair level in all estimations. ${ }^{28}$

Table 3 presents the results for conflict presence when all neighboring states are assigned the same average weight in the regional conflict measure as in (16). In the OLS estimation, when only time effects are included along with the traditional gravity variables, the estimated coefficients of the control variables are plausible and in line with earlier studies. For example, larger economies trade more, as do countries that share a common currency, border, language, and free trade agreement, but distance reduces bilateral trade. ${ }^{29}$ The war variable in this specification is a dummy variable that takes the value of one if at least one of the countries in the dyad is involved in any type of conflict (civil, international or both). As expected, the estimated coefficient for this variable is significantly negative, indicating that conflict involvement of the trading partners disrupts their trade flows.

Importantly, the estimated coefficient of our main variable of interest, neighbor at war - as measured by the societal (ncivconfd) and overall conflict (nconflictd) indicators - supports the main predictions of the model and shows that the presence of regional conflict affects bilateral

\footnotetext{
${ }^{27} \mathrm{We}$ also estimate the gravity model with the random effects model. However, in all cases, the Hausman testbased on the differences between the fixed and random effects models - fails to confirm the hypothesis that the explanatory variables are uncorrelated with the unobserved omitted variables.

${ }^{28}$ The model is also estimated with robust standard errors assuming cross-sectional dependence of the country pair panels. The estimation results are however very similar to those presented here and are available upon request.

${ }^{29}$ Current colony (curcol) is the only variable for which we obtain a counter intuitive result. This is possibly the result of low variation in the variable - we have only 14 observations for which this dummy variable is equal to one.
} 
trade flows negatively. The impact of international conflict (nintconfd) in contiguous states is negative but insignificant in the OLS specification. In addition, we find that good institutions in neighboring countries - proxied by the median polity index score-have a positive, albeit small, impact on bilateral trade. We also estimate equation (15) with the average regional income and income per capita for the trading partners instead of the polity score, but the results remain essentially the same and are not reported here for brevity.

When the CFE are included to the model, the fit of the estimated equation improves. The size of the estimated coefficients for ncivconfd and nconflictd drops slightly but holds significance at the one percent level, and the effect of neighborhood involvement in international conflicts also becomes significantly negative. Controlling for the CPFE and CYPFE, as in the last two columns for each type of conflict measure, we lose the cross-sectional information of the data and all time invariant variables drop from the estimation. However, the estimated coefficients of war and neighbor at war variables remain broadly the same. Bilateral trade flows are estimated to be, on average, about 12 percent $\left(e^{-0.13}-1=0.12\right)$ lower if at least one trading partner is involved in conflict. The effect of conflict in the neighbors can be computed by predicting the impact from conflict in an additional neighbor. By definition, the effect of an additional conflict in the neighborhood depends on the estimated coefficient for Nwar and the number of neighbors. The average number of neighbors for a country in our sample is four, implying that the average weight for each neighbor in the bilateral measure is $1 / 8=0.125$. Therefore, the estimated change in bilateral trade flows as a result of an additional conflict in the neighborhood is a reduction of about 2 and 3 percent for intrastate and international conflicts, respectively, as implied by the CPFE and CYPFE models. ${ }^{30}$

The results for conflict intensity — as measured by the average of the conflict magnitude scoresfurther support the finding that conflict in contiguous states reduces bilateral trade flows. Specifically, the estimates presented in Table 4 suggest that a one standard deviation increase in the sum of the neighborhood conflict intensity scores for the dyad reduces bilateral trade by about 7 and 3 percent for intrastate and international conflicts, respectively. ${ }^{31}$ In comparison, a one standard deviation increase in the intensity of domestic conflict in a dyad is associated with about a 9 percent decline in bilateral trade. This estimate is close to that of Blomberg and Hess (2006), who find that a one standard deviation shock to their indicator for violence in dyads - a composite measure for external war, inter-ethnic conflict and genocide, revolution and coups, and terrorism - reduces bilateral trade by 8.4 percent.

In Table 5, we present the results for the border length weighted conflict presence and intensity measures. ${ }^{32}$ The estimated impact of an additional neighbor at war is computed along the same lines as above, with the only difference that we use the average border length of a neighbor as a weight instead of the number of neighbors. The predicted change in bilateral trade flows as a result of an additional societal and international conflict in the region is the same as before (a

\footnotetext{
${ }^{30}$ These are obtained as $(\exp (-0.16 * 0.125)-1=0.02)$ and $(\exp (-0.21 * 0.125)-1=0.03)$, respectively.

${ }^{31}$ The impacts are computed as (exp $\left(\beta^{*}\right.$ std.dev $\left.)-1\right)^{*} 100$ where the standard deviation of the sum of the (average) neighborhood intrastate and international conflict intensity scores for the dyads are 1.73 and 0.60 , respectively.

${ }^{32}$ The estimated sample size drops as we use the strict definition of land contiguity in this case (see footnote 18).
} 
drop in bilateral trade flows of 2-3 percent, while the estimates for societal and international conflict intensity imply that increasing the joint score of the dyad by one standard deviation would reduce their trade by about 6 and 4 percent, respectively.

Taken together, the results from our four different types of measures constructed for societal, international and both types of conflict suggest moderate but strong negative spillovers from nearby conflicts. These results hold when controlling for domestic warfare and other regional characteristics such as polity and income, indicating that our findings with respect to conflicts in neighbors are not simply picking up effects of other related phenomenon, but are important in their own right. Further, these estimates present the direct impact of regional warfare only, and in this respect are likely to present a lower bound of its total effect on trade. If, for example, conflict in neighboring countries increases the likelihood of conflict in host economy - as shown by Hegre and Sambanis (2006) — then an indirect effect on trade through domestic conflict would also set in. To get some idea of the magnitude of this additional effect, we use the estimate of Hegre and Sambanis (2006) — which suggests that a neighbor at war increases the host country's likelihood of civil war onset by about 32 percent. For an economy with the existing probability of civil war at say, for example, 10 percent, this estimate implies an increase in the probability of civil conflict to about 13 percent with a neighbor in conflict - the rise in probability when combined with our estimate of the effect of domestic conflict on bilateral trade (12 percent), suggests an additional reduction in trade by about half a percentage points as a result of the spillover of neighborhood societal warfare to the host economy.

\section{B. Subsamples}

To investigate the trade effects of regional conflicts across various income groups, we estimate equation (15) using the different measures of regional conflict for the high-high, high-low and low-low dyads. The results presented in Tables 6 through 9 provide strong evidence that bilateral trade between high-high and high-low dyads is adversely affected by regional as well as domestic conflict. Adding one additional neighbor with some type of conflict to a trading partner in the high-high and high-low dyads is estimated to reduce trade between them by about 4 and 5 percent, respectively. However, the pair is estimated to trade, on average, about 10 percent less if at least one of the trading partners is itself involved in some form of conflict.

The impact of neighbors' and host economy war is much less clear for the low-low dyads. For example, for the measures indicating conflict presence, the estimated coefficients suggest a negligible effect of regional conflicts on bilateral trade, but a strong adverse effect of host country war. This finding is reversed for the measures of conflict intensity where neighbor at war has a much stronger impact than host economy war. The apparent weak relationship is possibly the result of much lower variation in the conflict presence and intensity variables for the low-low subsample. As shown in Table 2, about 90 percent of the observations in the low-low sample reflect regional conflict, making it difficult to draw meaningful conclusions from the estimations. For this reason, we define another sample for the low income group, which includes all trading partners (both high and low) and reestimate equation (15). The results (not reported here for brevity) indicate a strong negative effect of both regional and domestic conflict on trade of about 5 and 12 percent, respectively. 
While the results estimated from the world and subsamples consistently indicate a strong negative impact of regional conflicts on bilateral trade, it is also important to assess what our results imply for the change in conflict prevalence and trade between countries. For this purpose, using the CPFE estimates for the world, high income and low income samples, we simulate the effect of changes in societal and international conflict measures - holding everything else constant at the 2006 level — on bilateral trade. Specifically, we answer the counterfactual question that what would be the change in (predicted) trade between countries in 2006, if there are no regional societal and international conflicts, or if they were at the 1950 and 1980 levels. The results of this exercise, graphically shown in Figure 5, indicate that total trade between countries would be about 6 percent higher had there been no regional societal conflict in 2006, and about 2 percent higher had it been at the 1950 level. For international conflicts in neighboring states, the estimated trade would be about 2 and 10 percent higher than if there was no conflict, or if conflict is brought back to the 1950 level when international conflicts were much more widely prevalent than today, respectively.

\section{Dynamic effects of neighbors at war}

Most conflicts, particularly, intrastate civil and ethnic, tend to last over a long time period. For example, a dyad experiences continuous intrastate conflict in the neighborhood for an average duration of 15 years in our sample. This average is higher-about 21 years - for low-low dyads, and 9 years for high-high dyads. Protracted conflicts are likely to cause greater damage to the transportation infrastructure, lead to further thickening of borders as the risk of conflict spillover increases, and increase the uncertainty faced by traders. These factors imply that the effects of regional conflicts could be dynamic in nature with the duration having important consequences for a dyad's trading activity. In addition, the effects of conflict could be persistent such that it may take some time for trading activity to resume even after a conflict ends as confidence rebuilds and economic links are reestablished. In order to get a clear picture of the dynamic effects of regional warfare, it is therefore important to investigate whether the effects of a change in the conflict status manifest immediately, or only with time.

To explore the effect of conflict duration on bilateral trade, we include a variable in equation (15) that reflects the number of years that a trading pair has experienced conflict in at least one of its neighboring states. Since the effect of duration may be nonlinear, we also add the quadratic term for this variable to the model. The estimated results for the augmented specification reported in Table 10 indicate that the length a dyad experiences neighborhood conflict matters, particularly for the trade of low income countries. On average, an additional year of warfare in the neighborhood decreases bilateral trade by about 1 percent. The quadratic term for duration is negative and significant, albeit small, suggesting some diminishing returns of regional conflict duration. To see the effect of individual years since the onset of regional conflict we estimate another augmented specification, which includes dummy variables for each year into the conflict. Figure 6 graphically plots the estimated coefficients for the dummy variables, which show that the negative effect of successive years of regional conflict is significant, and increases gradually up to 40 years before exhibiting a declining trend.

To examine persistence in the trade destructing effects of conflicts, we examine the lag in recovery after the regional conflicts end. For this purpose, we include a dummy variable, nwarend, to equation (15) which is equal to one for the first year after a given type of conflict 
ends. The results presented in Table 11 reveal interesting differences in recovery from societal and international conflicts in the region. For example, columns (1)-(6) show that for societal conflict, the estimated coefficient for $n$ warend is positive but not statistically significant. However, the impact of $n$ warend is significantly negative for international conflicts, suggesting that the adverse effects of such conflicts in the neighborhood remain strong for at least a short while even after the end of the war.

To estimate the average number of years for recovery of bilateral trade from regional conflict, we sequentially include lagged terms for nwarend for both societal and international conflicts. The obtained results show that, on average, it could take as long as three years for the post-societal conflict impact to manifest itself. The persistence in regional warfare effects appears longer for international conflicts, and the average recovery time is estimated to be four years with the postconflict benefits becoming significant in the fifth year. For the high income group, however, the average recovery time appears shorter-2 years for regional societal conflicts and 3 years for regional international conflicts (see Table 12).

\section{Sensitivity analysis}

The results presented in Tables 3-9 verify the robustness of our estimates to various estimation methods and regional conflict measures. However, several other concerns pertaining to definition, model specification, and methodology raised in earlier literature may be relevant to our analysis. In what follows, we attempt to address these concerns through a battery of robustness checks.

\section{Alternate conflict datasets}

As discussed in Section II.C, a large number of conflict datasets are available that differ in their approach to defining conflict and coding conflict episodes. An advantage of having such a diversity is that alternative datasets could be used to check the validity of results to other definitions of conflict. Here, we use conflict information from two other datasets that are most commonly used in empirical literature-Sambanis (2004) and the UCDP. Both of these datasets define conflict in a somewhat different manner to the CIDCM-CSP's MEPV database, but span almost the same time period, and hence are suitable for a comparative analysis.

Sambanis (2004) dataset covers civil wars only, and codes armed conflict as civil wars if they conform to certain coding rules. Specifically, civil wars are defined as armed conflicts between an internationally recognized state and mainly domestic challengers able to create an organized military opposition to the state that caused more than 1,000 deaths in total, and no less than 500 deaths in a 3-year period. Using this definition, Hegre and Sambanis (2006) provide a binary variable "neighbor at war", which is equal to one if at least one neighboring country has a civil war in a given year and zero otherwise. They also provide information on the total numbers of neighbors at war for each country-year observation. Their dataset documents 2,589 country-year observations of civil wars in neighboring countries over the period 1948-2000.

In contrast to Sambanis (2004), the UCDP dataset - originally compiled by Gleditsch et al. (2002) — defines an armed conflict as a "contested incompatibility that concerns government and/or territory where the use of armed force between two parties, of which at least one is the 
government of a state, results in at least 25 battle-related deaths." By employing a lower annual fatality threshold, this dataset also includes information on low and intermediate intensity conflicts. In addition, conflicts are classified as: (i) extrasystemic — occurring between a state and a non-state group outside its own territory; (ii) interstate-occurring between two or more states; (iii) internal-occurring between the government of a state and one or more internal opposition group(s) without intervention from other states; and (iv) internationalized internal armed conflict - occurring between the government of a state and one or more internal opposition group(s) with intervention from other states on one or both sides.

To construct proxies for neighbors at war with the UCDP dataset, we follow the same steps as outlined in Section II.C and combine information on conflict types (ii)-(iv) with the contiguity data of Stinnett et al. (2002) to obtain country-year observations of the total number of neighbors involved in different types of conflict. From this variable, we construct a dummy variable indicating if at least one neighboring state is at war in a particular year. These regional conflict proxies as well as the neighbor at war variables from Sambanis (2004) are then combined with the bilateral trade dataset for estimation purposes.

The estimation results for equation (15) with the new set of conflict variables are presented in Table B1. In all cases, except for UCDP's interstate conflict with no international involvement, we find that the proxies for neighbor at war and host war are strongly negative, while the neighbor median polity score is significantly positive. However, the magnitude of the estimated coefficients varies across the conflict definitions. For example, for Sambanis (2004) dataset, the results suggest that bilateral trade is reduced by about 5 percent $\left(e^{-0.05}-1=0.05\right)$ if at least one trading partner has a neighbor involved in civil war. Based on the UCDP's definitions, we find that bilateral trade is reduced by 10 and 14 percent if at least one trading partner has a neighbor involved in international and internationalized intrastate conflicts, respectively. The effect of host country involvement in conflict (that is, if at least one trading partner is itself involved in conflict) is in the range of 11 to 16 percent across the various definitions.

\section{Alternate conflict measures}

To check the sensitivity of our results to other definitions of the regional conflict variable based on the MEPV dataset, we construct several other composite measures for neighborhood conflict. These include the unweighted sum of the neighborhood magnitude scores for different types of conflicts; the total number of contiguous states involved in each type of conflict; and a measure based on the first principal component obtained through the principal component analysis of the ncivconf and nintconf variables.

The results of this exercise are reported in Table B2. Columns (1)-(4) present the results when the sum of magnitude scores for the societal and international conflict measures and the number of contiguous states involved in each type of conflict are used to reflect regional warfare. Columns (5)-(7) present the results for different composite measures where the societal and international measures are combined as simple sums or through the principal component analysis. In each case, there is a strong negative impact of regional warfare, in addition to the negative impact of domestic conflict, and a positive impact of the median polity score of neighboring countries. 


\section{Model specification and estimation}

The estimation of the gravity model raises several model specification and estimation concerns, which have been extensively discussed in earlier literature (see, for example, Baldwin (2006)). We attempted to address the concerns related to the inclusion of the appropriate fixed effects to account for the multilateral resistance term by estimating the model with several proposed estimators in the main analysis. However, we address some other relevant issues by changing the model specification and estimation methodology in several ways.

First, we construct the dependent variable as the average of the logarithm of exports and imports (rather than the logarithm of the average) as proposed by some critics, and re-estimate the benchmark specification using composite measures for conflict presence and intensity. The results reported in Table B3 show that this has no effect whatsoever on the results. Second, we add quadratic terms for output and output per capita to the baseline specification to control for possible sample nonlinearities. Once again, the results are similar to those obtained earlier: the estimated impact of neighborhood conflict remains significantly negative, while host country conflict also reduces bilateral trade.

Third, we address the issue of zero-trade observations that commonly arises in bilateral datasets either because some dyads did not trade, or because of rounding errors and missing observations. Using the log-linear form of the gravity equation as in equation (15) implies including only those observations for which the dependent variable is positive. Given that trade flows between some pairs of countries - typically pairs of small countries - tends to be zero, truncation at zero may result in inconsistent estimators when ordinary least squares (OLS) are used. We check the sensitivity of our results to the inclusion of zero-trade observations by applying the Poisson pseudo maximum likelihood (PPML) approach applied by Santos Silva and Tenreyro (2006). The PPML approach takes the real value of trade as the dependent variable, and includes zero observations in the estimation. As a result, our sample size increases substantially (by about 25 percent). The results obtained from this approach - reported in the last column under each composite measure in Table B3 - are very similar to those obtained earlier, except for the estimated impact of international conflicts which appears to be positive hence counter intuitive.

\section{Simultaneity concerns}

As discussed in Section II.B, endogeneity concerns between conflict and trade are less relevant in our study because of the way host economy conflicts are defined. However, to alleviate any concerns about possible endogeneity, we estimate equation (15) using the instrumental variable (IV) methodology, where we employ total number of military personnel on active duty (as a percentage of total labor force) to instrument for conflicts. This variable is expected to be significantly correlated with conflict involvement, as countries with conflict or a history of conflict are likely to have a relatively large military force. 
The validity of our instrument (milpers) is supported by the results from the first stage of the IV estimation presented in Table B4: the estimated coefficient of milpers is highly significant (and expectedly positive) in all regressions. ${ }^{33}$ The F-test of the hypothesis that the estimates in the first stage regression are jointly equal to zero is not accepted, offering more evidence on the appropriateness of our instrument. Furthermore, the Sargan-Hansen test on the validity of the excluded instruments cannot be rejected indicating that the instruments are uncorrelated with the error term. The results of the second stage of the estimation still indicate that warfare in the trading partners has a strong negative effect on their trade. The magnitude of the effect is however somewhat larger, showing a reduction in bilateral trade of about 39 percent as trading partners experience some form of conflict. $^{34}$

\section{Alternate subsamples}

Table B5 presents some further robustness results of the impact of conflict on trade across different regions using the CPFE method. We show the results for the conflict intensity variables (ncivconf, nintconf, and nconflict), but the results for conflict presence and the border weighted conflict measures are similar (and are available on request). In each case, except for column 3 , we find a negative estimated effect that is highly statistically significant. The insignificant estimated coefficient for international conflict in the region for South Asia is not surprising considering that neighboring countries in the region have mostly been involved in intrastate conflict. To gauge the magnitude of the effect of neighborhood conflict across regions, we give a one standard deviation shock to the nconflict variable in each case, and find that East Asia reacts the most strongly with a reduction of trade by about 20 percent followed by South Asia (12 percent) and Latin America (10 percent). The strong influence of neighboring countries across regions reinforces the results obtained earlier, and shows that the estimated impact of neighboring conflict is not driven by any particular region.

\section{Conclusion}

This paper examines a previously unexplored channel through which warfare may have macroeconomic consequences for countries: the disruption of international trade flows as a result of conflict in neighboring states. Our empirical findings - based on different measures of regional conflict constructed using alternate definitions of contiguity and types of conflict for the period 1948-2006 - support the hypothesis that warfare in neighboring states imposes significant collateral damage in terms of foregone trade that is in addition to the negative effect of conflict in the host economies. The magnitude of this negative externality is somewhat larger for international conflicts than intrastate warfare, and about one-third of that for conflict in the host economies.

\footnotetext{
${ }^{33}$ The size of the sample is reduced as the relevant data, obtained from the World Bank's WDI, is available for the period 1988-2006 only.

${ }^{34}$ Using different instrumental variables (specifically, UN voting records, and dummy variables for international peace treaties), Blomberg and Hess (2006) report a substantial increase in the estimated magnitude of the coefficients for their violence measures.
} 
The findings also reveal that the impact of regional conflicts is persistent and increasing in duration - on average, it takes bilateral trade three years to recover from the end of interstate conflicts in neighboring states, and five years from international conflicts. Further, our results point to the existence of positive externalities stemming from good governance in contiguous states. Specifically, while controlling for any conflicts in the neighborhood, we find that having institutionally weak neighbors has significant adverse implications for the bilateral trade of a given dyad. Our findings are robust to alternate definitions of conflict, estimation methods, model specification, and subsamples.

The new empirical findings presented here support the literature on regional spillover effects and contagion, and underscore the importance of taking into account the systemic impact of conflicts when estimating the economic costs of warfare. Our empirical analysis, however, does not empirically identify whether this impact sets in because of demand or supply side effects. Both effects are possible and deserve further empirical study. In addition, the effect of neighboring conflict is likely to be higher for landlocked regions; countries with commercial centers and international transportation routes located closer to the neighbor's conflict zone; in the presence of conflict on the neighbor's territory rather than in another geographical region; and for certain types of products (for example, heavy goods which have higher transportation costs). In this respect, the paper presents a lower bound of estimates and proposes these issues as avenues for further research. From a policy perspective, the results presented here reinforce the importance of enhanced regional and international efforts for conflict prevention and mitigation as, evidently, the economic dividends from peace extend far beyond the countries directly involved in conflicts. 


\section{REFERENCES}

Abadie, A., and J. Gardeazabal, 2003, "The Economic Costs of Conflict: A Case Study of the Basque Country," American Economic Review, Vol. 93, No. 1, pp. 113-132.

Alesina, A., and R. Perotti, 1993, "Income Distribution, Political Instability, and Investment," NBER Working Paper No. 4486 (Cambridge, MA: National Bureau of Economic Research)

Anderson, J. E., and E. van Wincoop, 2003, "Gravity with Gravitas: A Solution to the Border Puzzle,” American Economic Review, Vol. 93, No. 1, pp. 170-192.

Anderson, J. E., and E. van Wincoop, 2004, “Trade Costs," Journal of Economic Literature, Vol. 42, No. 3, pp. 691-741.

Baier, S., and J. H. Bergstrand, 2007, “Do Free Trade Agreements Actually Increase Members' International Trade?," Journal of International Economics, Vol. 71, No. 1, pp. 72-95.

Barbeiri, K., 2002, The Liberal Illusion, Does Trade Promote Peace? (Ann Arbor: The University of Michigan Press).

Barro, R. J., 1991, "Economic Growth in a Cross Section of Countries," Quarterly Journal of Economics, Vol. 106, No. 2, pp. 407-443.

Blomberg, S. B., G. D. Hess, and A. Orphanides, 2004, “The Macroeconomic Consequences of Terrorism," Journal of Monetary Economics, Vol. 51, No. 5, pp. 1007-1032.

Blomberg, S. B., and G. D. Hess, 2006, “How Much Does Violence Tax Trade?” The Review of Economics and Statistics, Vol. 88, No. 4, pp. 599-612.

Brown, M., 1996, “The Causes and Regional Dimensions of Internal Conflict," in, (eds.), The International Dimensions of Internal Conflict (Cambridge, MA: The MIT Press).

Claessens, S., and K. J. Forbes, 2001, International Financial Contagion (Norwell, MA: Kluwer Academic Publisers).

Collier, P., 1999, “On the Economic Consequences of Civil War," Oxford Economic Papers, Vol. 51, No.1, pp. 161-183.

Collier, P., and A. Hoeffler, 2004, "The Challenge of Reducing the Global Incidence of Civil War, " Paper prepared for the 'Copenhagen Consensus 2004', Environmental Assessment Institute, Copenhagen.

Chauvet, L., P. Collier, and A. Hoeffler, 2007, "Paradise Lost: The Costs of State Failure in the Pacific,” WIDER Research Paper RP2007-16 (Helsinki: United Nations UniversityWorld Institute for Development Economics Research). 
De Groot, Olaf J., 2009, "The Spillovers of Conflict on Economic Growth in Neighbouring Countries in Africa," Defence and Peace Economics (forthcoming).

Deardorff, A., 1998, "Determinants of Bilateral Trade: Does Gravity Work in a Neoclassical World?," in The Regionalization of the World Economy (Cambridge, MA: National Bureau of Economic Research).

Fearon, J. D., and D. D. Laitin, 2003, "Ethnicity, Insurgency and Civil War," American Political Science Review, Vol. 97, pp. 75-90.

Fratianni, M., and H. Kang, "International Terrorism, International Trade, and Borders," Research in Global Strategic Management, Volume 12, pp. 203-223.

Gasiorowski, M. J., “Economic Interdependence and International Conflict: Some CrossNational Evidence," International Studies Quarterly, Vol. 30, pp. 23-38.

Gleditsch, N., H. Strand, M. Eriksson, M. Sollenberg, and P. Wallensteen, 2001, "Armed Conflict 1946-99: A New Dataset,” http://hypatia.ss.uci.edu/gpacs/newpages/agenda.htm.

Glick, R., and A. Rose, 2002, "Does a Currency Union Affect Trade? The Time-Series Evidence," European Economic Review, Vol. 46, No. 6, pp. 1125-1151.

Glick, R., and A. M. Taylor, 2005, "Collateral Damage: Trade Disruption and the Economic Impact of War,” NBER Working Paper No. 11565 (Cambridge, MA: National Bureau of Economic Research. (Forthcoming, Review of Economics and Statistics).

Gowa, J., 1994, Allies, Adversaries, and International Trade (Princeton, NJ: Princeton University Press).

Hegre, H., and N. Sambanis, 2006, "Sensitivity Analysis of Empirical Results on Civil War Onset," Journal of Conflict Resolution, Col. 50, No. 4, pp. 508-535.

Harbom, L., and P. Wallensteen, 2009, “Armed Conflict, 1946-2008,” Journal of Peace Research, Vol. 46, No. 4, pp. 577-587.

Holod, D., and R. Reed, III, 2004, "Regional Spillovers, Economic Growth, and the Effects of Economic Integration,” Economics Letters, Vol. 85, No. 1, pp. 35-42.

Mansfield, E. D., and R. Bronson, 1997, “Alliances, Preferential Trading Arrangements, and International Trade," American Political Science Review, Vol. 91, No. 1, pp. 97-104.

Marshall, M., 2009, Major Episodes of Political Violence (MEPV) and Conflict Regions 19462008, Center For Systemic Peace (Online: http://www.systemicpeace.org/inscr/inscr.htm)

Martin, P., T. Mayer, and M. Thoenig, 2008, "Make Trade Not War?," Review of Economic Studies, vol. 75, pp. 865-900. 
Mirza, D., and T. Verdier, 2008, "International Trade, Security and Transnational Terrorism: Theory and a Survey of Empirics," Journal of Comparative Economics, Vol. 36, No. 2, pp. 179-194.

Mirza, D., J. Sousa, and T. Verdier, 2009, “Terrorism and Trade: Does the Neighbor Hurt?" Paper presented at FREIT Conference on Empirical Investigations in International Trade, Ljubljana, June 11-13, 2009.

Murdoch, J., and T. Sandler, 2002, "Economic Growth, Civil Wars, and Spatial Spillovers," Journal of Conflict Resolution, Vol. 46, No. 1, pp. 91-110.

Murdoch, J., and T. Sandler, 2004, "Civil Wars and Economic Growth: Spatial Spillovers," American Journal of Political Science, Vol. 48, No. 1, pp. 138-151.

Nitsh, V., and D. Schumacher, 2004, "Terrorism and International Trade: An Empirical Investigation," European Journal of Political Economy, Vol. 2, No. 2, pp. 423-433.

Oneal, J., and B. Russett, 1999, “Assessing the Liberal Peace with Alternative Specifications: Trade Still Reduces Conflict", Journal of Peace Research, Vol. 36, No. 4, pp. 423-442.

Polachek, S. W., 1992, "Why Democracies Cooperate More and Fight Less: the Relationship Between, International Trade and Cooperation," Review of International Economics, Vol. 5, pp. 295-309.

Pollins, B., 1989, "Conflict, Cooperation, and Commerce: The Effect of International Political Interactions Upon Bilateral Trade Flows," American Journal of Political Science, Vol. 33, No. 3, pp. 737-761.

Reuveny, R., and H. Kang, 2003, "A Simultaneous-Equations Model of Trade, Conflict, and Cooperation," Review of International Economics, Vol. 11, No. 2, pp. 279-295.

Sambanis, N., 2001, "Do Ethnic and Nonethnic Civil Wars Have the Same Causes? A Theoretical and Empirical Inquiry (Part 1)," Journal of Conflict Resolution, Vol. 45, No. 3 , pp. 259-282.

Sambanis, N., 2004, "What is a Civil War? Conceptual and Empirical Complexities of an Operational Definition". Journal of Conflict Resolution, Vol. 48, No. 6, pp. 814-858.

Stinnett, D. M., J. Tir, P. Schafer, P.F. Diehl, and C. Gochman, 2002, "The Correlates of War Project Direct Contiguity Data, Version 3." Conflict Management and Peace Science, Vol. 19, No. 2, pp. 58-66.

World Bank, 1992, Trends in Developing Economies 1992 (Washington, DC: World Bank). 
Table 1. Correlation between domestic and regional conflicts, 1948-2006

\begin{tabular}{|c|c|c|c|c|c|c|c|c|c|}
\hline & civconf & intconf & conflict & ncivconf & nintconf & nconflict & ncivconfd & nintconfd & nconflictd \\
\hline civconf & 1.00 & & & & & & & & \\
\hline intconf & 0.13 & 1.00 & & & & & & & \\
\hline conflict & 0.93 & 0.49 & 1.00 & & & & & & \\
\hline ncivconf & 0.19 & 0.07 & 0.19 & 1.00 & & & & & \\
\hline nintconf & 0.07 & 0.37 & 0.20 & 0.14 & 1.00 & & & & \\
\hline nconflict & 0.19 & 0.19 & 0.24 & 0.93 & 0.50 & 1.00 & & & \\
\hline ncivconfd & 0.20 & 0.08 & 0.20 & 0.86 & 0.14 & 0.81 & 1.00 & & \\
\hline nintconfd & 0.07 & 0.28 & 0.17 & 0.13 & 0.87 & 0.43 & 0.15 & 1.00 & \\
\hline nconflictd & 0.19 & 0.15 & 0.22 & 0.79 & 0.39 & 0.84 & 0.92 & 0.44 & 1.00 \\
\hline
\end{tabular}

Table 2. Distribution of societal and international conflict in neighbors, 1948-2006

\begin{tabular}{|c|c|c|c|c|}
\hline & World & High-High & High-Low & Low-Low \\
\hline \multicolumn{5}{|l|}{ Total } \\
\hline Observations & 199,012 & 53,963 & 106,528 & 39,421 \\
\hline Country pairs & 9,024 & 2,039 & 4,718 & 2,267 \\
\hline \multicolumn{5}{|l|}{ Societal conflict ${ }^{\mathrm{a}}$} \\
\hline Ncivconf measure & 1.69 & 1.04 & 1.70 & 2.52 \\
\hline W_ncivconf measure & 1.71 & 0.96 & 1.70 & 2.66 \\
\hline Observations & 153,914 & 34,758 & 84,098 & 35,058 \\
\hline Country pairs & 8,800 & 1,944 & 4,639 & 2,217 \\
\hline \multicolumn{5}{|l|}{ International conflict ${ }^{b}$} \\
\hline Nintconf measure & 0.23 & 0.23 & 0.23 & 0.24 \\
\hline W_nintconf measure & 0.22 & 0.23 & 0.22 & 0.22 \\
\hline Observations & 47,001 & 11,285 & 25,242 & 10,474 \\
\hline Country pairs & 5,989 & 1,334 & 3,188 & 1,467 \\
\hline \multicolumn{5}{|l|}{ Overall conflict $^{c}$} \\
\hline Nconflict measure & 1.92 & 1.27 & 1.94 & 2.76 \\
\hline W_nconflict measure & 1.93 & 1.19 & 1.92 & 2.88 \\
\hline Trade (\% of total trade) & 100 & 81.7 & 17.0 & 1.3 \\
\hline Dyads with regional conflict $^{d}$ & 61.1 & 44.6 & 15.4 & 1.2 \\
\hline Dyads without regional conflict & 38.9 & 37.2 & 1.6 & 0.1 \\
\hline
\end{tabular}

Source: Author's calculations.

${ }^{\text {a }}$ At least one country in the trading pair has neighbor(s) involved in a societal conflict. Measure is defined as the

average of the neighborhood magnitude scores for civil violence, civil war, ethnic violence, and ethnic war.

${ }^{b}$ At least one country in the trading pair has neighbor(s) involved in an international conflict. Measure is defined as the average of the neighborhood magnitude scores for international violence, and international war.

${ }^{c}$ Overall conflict measure is the average magnitude score for neighborhood international and societal conflicts.

${ }^{d}$ At least one country in the pair has neighbor(s) involved in some type of conflict (societal, international or both). 
Table 3. Estimation results for conflict presence (world sample, 1948-2006)

\begin{tabular}{|c|c|c|c|c|c|c|c|c|c|c|c|c|}
\hline \multirow[b]{2}{*}{$\begin{array}{l}\text { Estimation } \\
\text { Specification }\end{array}$} & \multicolumn{4}{|c|}{ Societal (intrastate) conflict index ${ }^{1}$} & \multicolumn{4}{|c|}{ International conflict index ${ }^{2}$} & \multicolumn{4}{|c|}{ Overall conflict index ${ }^{3}$} \\
\hline & $\begin{array}{l}\text { OLS } \\
(1)\end{array}$ & $\begin{array}{c}\text { CFE } \\
(2) \\
\end{array}$ & $\begin{array}{c}\text { CPFE } \\
\text { (3) }\end{array}$ & $\begin{array}{c}\text { CYPFE } \\
(4) \\
\end{array}$ & $\begin{array}{l}\text { OLS } \\
(5)\end{array}$ & $\begin{array}{c}\text { CFE } \\
(6)\end{array}$ & $\begin{array}{c}\text { CPFE } \\
(7) \\
\end{array}$ & $\begin{array}{c}\text { CYPFE } \\
(8) \\
\end{array}$ & $\begin{array}{c}\text { OLS } \\
(9) \\
\end{array}$ & $\begin{array}{l}\text { CFE } \\
(10) \\
\end{array}$ & $\begin{array}{c}\text { CPFE } \\
(11) \\
\end{array}$ & $\begin{array}{c}\text { CYPFE } \\
(12)\end{array}$ \\
\hline Neighbor at war & $\begin{array}{c}-0.328^{* * *} \\
(0.04)\end{array}$ & $\begin{array}{c}-0.174^{* * *} \\
(0.03)\end{array}$ & $\begin{array}{c}-0.160^{\star * *} \\
(0.02)\end{array}$ & $\begin{array}{c}-0.152^{* * *} \\
(0.02)\end{array}$ & $\begin{array}{l}-0.041 \\
(0.06)\end{array}$ & $\begin{array}{c}-0.221^{* * *} \\
(0.03)\end{array}$ & $\begin{array}{c}-0.208^{* * *} \\
(0.03)\end{array}$ & $\begin{array}{c}-0.195^{* * *} \\
(0.03)\end{array}$ & $\begin{array}{c}-0.268^{* * *} \\
(0.04)\end{array}$ & $\begin{array}{c}-0.192^{* * *} \\
(0.02)\end{array}$ & $\begin{array}{c}-0.172^{* * *} \\
(0.02)\end{array}$ & $\begin{array}{c}-0.157^{* * *} \\
(0.02)\end{array}$ \\
\hline War $^{a}$ & $\begin{array}{c}-0.203^{* * *} \\
(0.03)\end{array}$ & $\begin{array}{c}-0.087^{* * *} \\
(0.02)\end{array}$ & $\begin{array}{c}-0.130^{* * *} \\
(0.02)\end{array}$ & $\begin{array}{c}-0.127^{* * *} \\
(0.02)\end{array}$ & $\begin{array}{c}-0.228^{* * *} \\
(0.03)\end{array}$ & $\begin{array}{c}-0.091^{* * *} \\
(0.02)\end{array}$ & $\begin{array}{c}-0.133^{* * *} \\
(0.02)\end{array}$ & $\begin{array}{c}-0.131^{* * *} \\
(0.02)\end{array}$ & $\begin{array}{c}-0.209^{* * *} \\
(0.03)\end{array}$ & $\begin{array}{c}-0.085^{* * *} \\
(0.02)\end{array}$ & $\begin{array}{c}-0.129^{* * *} \\
(0.02)\end{array}$ & $\begin{array}{c}-0.125^{* * \star} \\
(0.02)\end{array}$ \\
\hline Neighbor polity index & $\begin{array}{c}0.026^{* * *} \\
(0.00)\end{array}$ & $\begin{array}{l}0.001 \\
(0.00)\end{array}$ & $\begin{array}{c}0.004^{* *} \\
(0.00)\end{array}$ & $\begin{array}{c}0.003^{* *} \\
(0.00)\end{array}$ & $\begin{array}{c}0.026^{* * *} \\
(0.00)\end{array}$ & $\begin{array}{l}0.000 \\
(0.00)\end{array}$ & $\begin{array}{l}0.003^{*} \\
(0.00)\end{array}$ & $\begin{array}{l}0.002^{*} \\
(0.00)\end{array}$ & $\begin{array}{c}0.025^{* * *} \\
(0.00)\end{array}$ & $\begin{array}{l}0.001 \\
(0.00)\end{array}$ & $\begin{array}{l}0.003^{*} \\
(0.00)\end{array}$ & $\begin{array}{l}0.003^{*} \\
(0.00)\end{array}$ \\
\hline Lrgdp & $\begin{array}{c}1.108^{* * *} \\
(0.01)\end{array}$ & $\begin{array}{c}-0.222^{* * *} \\
(0.06)\end{array}$ & $\begin{array}{c}0.389^{* * *} \\
(0.05)\end{array}$ & & $\begin{array}{c}1.102^{* * *} \\
(0.01)\end{array}$ & $\begin{array}{c}-0.223^{* * *} \\
(0.06)\end{array}$ & $\begin{array}{c}0.389^{* * *} \\
(0.05)\end{array}$ & & $\begin{array}{c}1.108^{* * *} \\
(0.01)\end{array}$ & $\begin{array}{c}-0.212^{* * *} \\
(0.06)\end{array}$ & $\begin{array}{c}0.397^{* * *} \\
(0.05)\end{array}$ & \\
\hline Lrgdppc & $\begin{array}{c}-0.213^{* * *} \\
(0.02)\end{array}$ & $\begin{array}{c}0.452^{* * *} \\
(0.06)\end{array}$ & $\begin{array}{c}-0.197^{\star * \star} \\
(0.05)\end{array}$ & & $\begin{array}{c}-0.191^{* * *} \\
(0.02)\end{array}$ & $\begin{array}{c}0.452^{\star * *} \\
(0.06)\end{array}$ & $\begin{array}{c}-0.198^{* * *} \\
(0.05)\end{array}$ & & $\begin{array}{c}-0.208^{* * *} \\
(0.02)\end{array}$ & $\begin{array}{c}0.441^{* * *} \\
(0.06)\end{array}$ & $\begin{array}{c}-0.206^{* * *} \\
(0.05)\end{array}$ & \\
\hline Ldist & $\begin{array}{c}-1.232^{* * *} \\
(0.03)\end{array}$ & $\begin{array}{c}-1.360^{* * *} \\
(0.03)\end{array}$ & & & $\begin{array}{c}-1.236^{* * *} \\
(0.03)\end{array}$ & $\begin{array}{c}-1.360^{* * *} \\
(0.03)\end{array}$ & & & $\begin{array}{c}-1.233^{* * *} \\
(0.03)\end{array}$ & $\begin{array}{c}-1.360^{* * *} \\
(0.03)\end{array}$ & & \\
\hline $\mathrm{CU}$ & $\begin{array}{c}0.416^{* * *} \\
(0.16)\end{array}$ & $\begin{array}{c}0.552^{* * *} \\
(0.15)\end{array}$ & $\begin{array}{c}0.364^{* * *} \\
(0.10)\end{array}$ & $\begin{array}{c}0.301^{* * *} \\
(0.09)\end{array}$ & $\begin{array}{c}0.453^{* * *} \\
(0.16)\end{array}$ & $\begin{array}{c}0.554^{* * *} \\
(0.15)\end{array}$ & $\begin{array}{c}0.365^{* * *} \\
(0.10)\end{array}$ & $\begin{array}{c}0.278^{* * *} \\
(0.09)\end{array}$ & $\begin{array}{c}0.416^{\star \star *} \\
(0.16)\end{array}$ & $\begin{array}{c}0.551^{* * *} \\
(0.15)\end{array}$ & $\begin{array}{c}0.362^{* * *} \\
(0.10)\end{array}$ & $\begin{array}{c}0.289^{* * *} \\
(0.10)\end{array}$ \\
\hline FTA & $\begin{array}{c}0.688^{* * *} \\
(0.09)\end{array}$ & $\begin{array}{c}0.339^{* * *} \\
(0.10)\end{array}$ & $\begin{array}{c}0.300^{* * *} \\
(0.07)\end{array}$ & $\begin{array}{c}0.258^{* * *} \\
(0.05)\end{array}$ & $\begin{array}{c}0.711^{* * *} \\
(0.09)\end{array}$ & $\begin{array}{c}0.334^{* * *} \\
(0.10)\end{array}$ & $\begin{array}{c}0.290^{* * *} \\
(0.07)\end{array}$ & $\begin{array}{c}0.275^{* * *} \\
(0.07)\end{array}$ & $\begin{array}{c}0.689^{\star * *} \\
(0.09)\end{array}$ & $\begin{array}{c}0.337^{* * *} \\
(0.10)\end{array}$ & $\begin{array}{c}0.297^{* * *} \\
(0.06)\end{array}$ & $\begin{array}{c}0.245^{\star * *} \\
(0.06)\end{array}$ \\
\hline Comlang & $\begin{array}{c}0.386^{* * *} \\
(0.05)\end{array}$ & $\begin{array}{c}0.491^{* * *} \\
(0.05)\end{array}$ & & & $\begin{array}{c}0.366^{* * *} \\
(0.05)\end{array}$ & $\begin{array}{c}0.491^{* * *} \\
(0.05)\end{array}$ & & & $\begin{array}{c}0.384^{* * *} \\
(0.05)\end{array}$ & $\begin{array}{c}0.491^{* * *} \\
(0.05)\end{array}$ & & \\
\hline Comborder & $\begin{array}{c}0.654^{* * *} \\
(0.12)\end{array}$ & $\begin{array}{c}0.657^{* * *} \\
(0.13)\end{array}$ & & & $\begin{array}{c}0.649^{* * *} \\
(0.12)\end{array}$ & $\begin{array}{c}0.658^{* * *} \\
(0.13)\end{array}$ & & & $\begin{array}{c}0.652^{* * *} \\
(0.12)\end{array}$ & $\begin{array}{c}0.657^{* * *} \\
(0.13)\end{array}$ & & \\
\hline Landl & $\begin{array}{c}-0.402^{* * *} \\
(0.04)\end{array}$ & $\begin{array}{l}0.414 \\
(0.35)\end{array}$ & & & $\begin{array}{c}-0.388^{* * *} \\
(0.03)\end{array}$ & $\begin{array}{l}0.421 \\
(0.35)\end{array}$ & & & $\begin{array}{c}-0.398^{* * *} \\
(0.04)\end{array}$ & $\begin{array}{l}0.429 \\
(0.35)\end{array}$ & & \\
\hline Island & $\begin{array}{c}0.570^{* * *} \\
(0.06)\end{array}$ & $\begin{array}{c}2.075^{* * *} \\
(0.31)\end{array}$ & & & $\begin{array}{c}0.458^{* * *} \\
(0.06)\end{array}$ & $\begin{array}{c}2.062^{* \star *} \\
(0.31)\end{array}$ & & & $\begin{array}{c}0.557^{* * *} \\
(0.06)\end{array}$ & $\begin{array}{c}2.099^{* * *} \\
(0.31)\end{array}$ & & \\
\hline Lareap & $\begin{array}{c}-0.106^{\star * *} \\
(0.01)\end{array}$ & $\begin{array}{c}0.552^{* * *} \\
(0.03)\end{array}$ & & & $\begin{array}{c}-0.102^{* * *} \\
(0.01)\end{array}$ & $\begin{array}{c}0.551^{* * *} \\
(0.03)\end{array}$ & & & $\begin{array}{c}-0.104^{* * *} \\
(0.01)\end{array}$ & $\begin{array}{c}0.550^{* * *} \\
(0.03)\end{array}$ & & \\
\hline Comcol & $\begin{array}{c}1.065^{\star \star \star} \\
(0.09)\end{array}$ & $\begin{array}{c}1.051^{\star * *} \\
(0.08)\end{array}$ & & & $\begin{array}{c}1.060^{* * *} \\
(0.09)\end{array}$ & $\begin{array}{c}1.051^{* * *} \\
(0.08)\end{array}$ & & & $\begin{array}{c}1.062^{* * *} \\
(0.09)\end{array}$ & $\begin{array}{c}1.051^{\star * *} \\
(0.08)\end{array}$ & & \\
\hline Curcol & $\begin{array}{c}-2.734^{* * *} \\
(0.14)\end{array}$ & $\begin{array}{c}-2.481^{* * *} \\
(0.19)\end{array}$ & $\begin{array}{c}-2.810^{* * *} \\
(0.03)\end{array}$ & $\begin{array}{c}-2.365^{* * *} \\
(0.03)\end{array}$ & $\begin{array}{c}-2.652^{* * *} \\
(0.14)\end{array}$ & $\begin{array}{c}-2.439^{* * *} \\
(0.19)\end{array}$ & $\begin{array}{c}-2.767^{* * *} \\
(0.03)\end{array}$ & $\begin{array}{c}-2.214^{* * *} \\
(0.03)\end{array}$ & $\begin{array}{c}-2.707^{* * *} \\
(0.14)\end{array}$ & $\begin{array}{c}-2.466^{* * *} \\
(0.19)\end{array}$ & $\begin{array}{c}-2.794^{* * *} \\
(0.03)\end{array}$ & $\begin{array}{c}-2.138^{* * *} \\
(0.03)\end{array}$ \\
\hline Evercol & $\begin{array}{c}1.223^{* * *} \\
(0.14)\end{array}$ & $\begin{array}{c}1.214^{* * *} \\
(0.14)\end{array}$ & & & $\begin{array}{c}1.262^{* * *} \\
(0.14)\end{array}$ & $\begin{array}{c}1.216^{* * *} \\
(0.14)\end{array}$ & & & $\begin{array}{c}1.229^{* * *} \\
(0.14)\end{array}$ & $\begin{array}{c}1.216^{* * *} \\
(0.14)\end{array}$ & & \\
\hline Constant & $\begin{array}{c}-22.20^{* * *} \\
(0.48)\end{array}$ & $\begin{array}{c}12.360^{* * *} \\
(1.66)\end{array}$ & $\begin{array}{l}0.249 \\
(1.86)\end{array}$ & $\begin{array}{l}0.122 \\
(1.80)\end{array}$ & $\begin{array}{c}-22.50^{* * *} \\
(0.47)\end{array}$ & $\begin{array}{c}12.370^{* * *} \\
(1.66)\end{array}$ & $\begin{array}{l}0.239 \\
(1.86)\end{array}$ & $\begin{array}{l}0.145 \\
(1.97)\end{array}$ & $\begin{array}{c}-22.34^{\star * *} \\
(0.47)\end{array}$ & $\begin{array}{c}12.100^{* * *} \\
(1.66)\end{array}$ & $\begin{array}{l}0.013 \\
(1.86)\end{array}$ & $\begin{array}{l}0.012 \\
(1.57)\end{array}$ \\
\hline Observations & 199,912 & 199,912 & 199,912 & 199,912 & 199,912 & 199,912 & 199,912 & 199,912 & 199,912 & 199,912 & 199,912 & 199,912 \\
\hline Number of pairid & & & 9,024 & 9,024 & & & 9,024 & 9,024 & & & 9,024 & 9,024 \\
\hline R-squared & 0.671 & 0.744 & 0.171 & 0.256 & 0.670 & 0.744 & 0.171 & 0.264 & 0.670 & 0.744 & 0.171 & 0.256 \\
\hline R2-within & & & 0.171 & 0.256 & & & 0.171 & 0.264 & & & 0.171 & 0.256 \\
\hline R2-between & & & 0.448 & 0.502 & & & 0.439 & 0.485 & & & 0.444 & 0.502 \\
\hline R2-overall & & & 0.355 & 0.372 & & & 0.345 & 0.363 & & & 0.354 & 0.372 \\
\hline Hausman test (p-value & & & 0.000 & 0.000 & & & 0.000 & 0.000 & & & 0.000 & 0.000 \\
\hline $\begin{array}{l}\text { Dependent variable is log } \\
\text { Robust clustered standard } \\
\text { ***, }{ }^{* \star} \text { and }{ }^{*} \text { indicate signif } \\
{ }^{a} \text { CFE }=\text { country-fixed effec } \\
\text { b } \text { Dummy variable equal to } \\
{ }^{1} \text { Sum of average number } \\
\text { ' Sum of average number } \\
\text { s Sum of average number }\end{array}$ & $\begin{array}{l}\text { icance at the } \\
\text { ts included; } \\
\text { of ne if at leas } \\
\text { of neighbors } \\
\text { of neighbors }\end{array}$ & $\begin{array}{l}\text { CPFE= coun } \\
\text { st one count } \\
\text { involved in } \\
\text { in internatio } \\
\text { in any type }\end{array}$ & $\begin{array}{l}\text { d } 10 \% \text { signi } \\
\text { try-pair fixe } \\
\text { try in the tra } \\
\text { civil and eth } \\
\text { onal violence } \\
\text { of conflict ( }\end{array}$ & $\begin{array}{l}\text { ficance leve } \\
\text { d effects inc } \\
\text { ding pair is } \\
\text { nic violence } \\
\text { e and war (n } \\
\text { nconflictd) f }\end{array}$ & $\begin{array}{l}\text { ls, respectiv } \\
\text { cluded; CYP } \\
\text { involved in a } \\
\text { e and war ( } \\
\text { nintconf } \text { ) for } \\
\text { or the trading }\end{array}$ & $\begin{array}{l}\text { tions. } \\
\text { ely. } \\
\mathrm{FE}=\text { country- } \\
\text { any type of } \mathrm{c} \\
\text { civconfd) fo } \\
\mathrm{r} \text { the trading } \\
\mathrm{g} \text { pair. }\end{array}$ & $\begin{array}{l}\text {-year and } \\
\text { conflict. } \\
\text { or the tradi } \\
\text { g pair. }\end{array}$ & $\begin{array}{l}\text { untry-pa } \\
\text { pair. }\end{array}$ & effe & luded. & & \\
\hline
\end{tabular}


Table 4. Estimation results for conflict intensity (world sample, 1948-2006)

\begin{tabular}{|c|c|c|c|c|c|c|c|c|c|c|c|c|}
\hline \multirow[b]{2}{*}{$\begin{array}{l}\text { Estimation } \\
\text { Specification }\end{array}$} & \multicolumn{4}{|c|}{ Societal (intrastate) conflict index ${ }^{1}$} & \multicolumn{4}{|c|}{ International conflict index ${ }^{2}$} & \multicolumn{4}{|c|}{ Overall conflict index ${ }^{3}$} \\
\hline & $\begin{array}{l}\text { OLS } \\
(1) \\
\end{array}$ & $\begin{array}{l}\text { CFE } \\
(2) \\
\end{array}$ & $\begin{array}{l}\text { CPFE } \\
(3) \\
\end{array}$ & $\begin{array}{c}\text { CYPFE } \\
(4) \\
\end{array}$ & $\begin{array}{c}\text { OLS } \\
(5) \\
\end{array}$ & $\begin{array}{c}\text { CFE } \\
(6) \\
\end{array}$ & $\begin{array}{c}\text { CPFE } \\
(7) \\
\end{array}$ & $\begin{array}{c}\text { CYPFE } \\
(8) \\
\end{array}$ & $\begin{array}{c}\text { OLS } \\
(9) \\
\end{array}$ & $\begin{array}{l}\text { CFE } \\
(10) \\
\end{array}$ & $\begin{array}{c}\text { CPFE } \\
(11) \\
\end{array}$ & $\begin{array}{c}\text { CYPFE } \\
(12) \\
\end{array}$ \\
\hline Neighbor at war & $\begin{array}{c}-0.066^{\star \star \star} \\
(0.01)\end{array}$ & $\begin{array}{c}-0.047^{\star \star *} \\
(0.01)\end{array}$ & $\begin{array}{c}-0.043^{* * *} \\
(0.01)\end{array}$ & $\begin{array}{c}-0.040^{* * *} \\
(0.01)\end{array}$ & $\begin{array}{l}0.015 \\
(0.02)\end{array}$ & $\begin{array}{c}-0.041^{* * *} \\
(0.01)\end{array}$ & $\begin{array}{c}-0.054^{* * *} \\
(0.01)\end{array}$ & $\begin{array}{c}-0.050^{* * *} \\
(0.01)\end{array}$ & $\begin{array}{c}-0.052^{* * *} \\
(0.01)\end{array}$ & $\begin{array}{c}-0.045^{\text {***}} \\
(0.01)\end{array}$ & $\begin{array}{c}-0.042^{* * *} \\
(0.01)\end{array}$ & $\begin{array}{c}-0.041^{* * *} \\
(0.01)\end{array}$ \\
\hline $\operatorname{War}^{a}$ & $\begin{array}{c}-0.053^{* * *} \\
(0.01)\end{array}$ & $\begin{array}{c}-0.038^{\star * *} \\
(0.01)\end{array}$ & $\begin{array}{c}-0.041^{* * *} \\
(0.00)\end{array}$ & $\begin{array}{c}-0.041^{* * *} \\
(0.00)\end{array}$ & $\begin{array}{c}-0.059^{\star \star \star} \\
(0.01)\end{array}$ & $\begin{array}{c}-0.041^{* * *} \\
(0.01)\end{array}$ & $\begin{array}{c}-0.043^{\star * *} \\
(0.00)\end{array}$ & $\begin{array}{c}-0.042^{* * *} \\
(0.00)\end{array}$ & $\begin{array}{c}-0.053^{* * *} \\
(0.01)\end{array}$ & $\begin{array}{c}-0.037^{\star * *} \\
(0.01)\end{array}$ & $\begin{array}{c}-0.039^{* * *} \\
(0.00)\end{array}$ & $\begin{array}{c}-0.039^{* * *} \\
(0.00)\end{array}$ \\
\hline Neighbor polity index & $\begin{array}{c}0.026^{* * *} \\
(0.00)\end{array}$ & $\begin{array}{l}0.001 \\
(0.00)\end{array}$ & $\begin{array}{c}0.004^{* *} \\
(0.00)\end{array}$ & $\begin{array}{c}0.005^{\star *} \\
(0.00)\end{array}$ & $\begin{array}{c}0.027^{\star * *} \\
(0.00)\end{array}$ & $\begin{array}{l}0.001 \\
(0.00)\end{array}$ & $\begin{array}{c}0.004^{* *} \\
(0.00)\end{array}$ & $\begin{array}{c}0.004^{* *} \\
(0.00)\end{array}$ & $\begin{array}{c}0.025^{\star * *} \\
(0.00)\end{array}$ & $\begin{array}{l}0.001 \\
(0.00)\end{array}$ & $\begin{array}{c}0.004^{* *} \\
(0.00)\end{array}$ & $\begin{array}{c}0.004^{* *} \\
(0.00)\end{array}$ \\
\hline Lrgdp & $\begin{array}{c}1.114^{\star \star *} \\
(0.01)\end{array}$ & $\begin{array}{c}-0.241^{* * *} \\
(0.06)\end{array}$ & $\begin{array}{c}0.369^{* * *} \\
(0.05)\end{array}$ & & $\begin{array}{c}1.106^{\star \star *} \\
(0.01)\end{array}$ & $\begin{array}{c}-0.226^{* \star *} \\
(0.06)\end{array}$ & $\begin{array}{c}0.385^{\star \star *} \\
(0.05)\end{array}$ & & $\begin{array}{c}1.113^{* * *} \\
(0.01)\end{array}$ & $\begin{array}{c}-0.236^{\star \star *} \\
(0.06)\end{array}$ & $\begin{array}{c}0.375^{\star \star *} \\
(0.05)\end{array}$ & \\
\hline Lrgdppc & $\begin{array}{c}-0.220^{\star * *} \\
(0.02)\end{array}$ & $\begin{array}{c}0.468^{* * *} \\
(0.06)\end{array}$ & $\begin{array}{c}-0.179^{* * *} \\
(0.05)\end{array}$ & & $\begin{array}{c}-0.199^{\star * *} \\
(0.02)\end{array}$ & $\begin{array}{c}0.453^{\star \star *} \\
(0.06)\end{array}$ & $\begin{array}{c}-0.196^{\star * *} \\
(0.05)\end{array}$ & & $\begin{array}{c}-0.215^{\star \star *} \\
(0.02)\end{array}$ & $\begin{array}{c}0.461^{* * *} \\
(0.06)\end{array}$ & $\begin{array}{c}-0.186^{* * *} \\
(0.05)\end{array}$ & \\
\hline Ldist & $\begin{array}{c}-1.235^{\star \star *} \\
(0.03)\end{array}$ & $\begin{array}{c}-1.362^{\star * *} \\
(0.03)\end{array}$ & & & $\begin{array}{c}-1.238^{* * *} \\
(0.03)\end{array}$ & $\begin{array}{c}-1.361^{* * *} \\
(0.03)\end{array}$ & & & $\begin{array}{c}-1.237^{\star \star *} \\
(0.03)\end{array}$ & $\begin{array}{c}-1.362^{\star \star *} \\
(0.03)\end{array}$ & & \\
\hline CU & $\begin{array}{c}0.416^{\star * *} \\
(0.16)\end{array}$ & $\begin{array}{c}0.553^{* * *} \\
(0.15)\end{array}$ & $\begin{array}{c}0.360^{\star * *} \\
(0.10)\end{array}$ & $\begin{array}{c}0.280^{\star * *} \\
(0.10)\end{array}$ & $\begin{array}{c}0.448^{* \star *} \\
(0.16)\end{array}$ & $\begin{array}{c}0.556^{\star \star \star} \\
(0.15)\end{array}$ & $\begin{array}{c}0.367^{\star \star *} \\
(0.10)\end{array}$ & $\begin{array}{c}0.307^{\star * *} \\
(0.10)\end{array}$ & $\begin{array}{c}0.414^{\star * *} \\
(0.16)\end{array}$ & $\begin{array}{c}0.554^{* * *} \\
(0.15)\end{array}$ & $\begin{array}{c}0.362^{* \star *} \\
(0.10)\end{array}$ & $\begin{array}{c}0.314^{\star * *} \\
(0.10)\end{array}$ \\
\hline FTA & $\begin{array}{c}0.675^{\star * *} \\
(0.10)\end{array}$ & $\begin{array}{c}0.337^{* * *} \\
(0.10)\end{array}$ & $\begin{array}{c}0.290^{* * *} \\
(0.07)\end{array}$ & $\begin{array}{c}0.205^{\star * *} \\
(0.07)\end{array}$ & $\begin{array}{c}0.705^{\star * *} \\
(0.09)\end{array}$ & $\begin{array}{c}0.335^{\star * *} \\
(0.10)\end{array}$ & $\begin{array}{c}0.287^{* * *} \\
(0.07)\end{array}$ & $\begin{array}{c}0.254^{* * *} \\
(0.07)\end{array}$ & $\begin{array}{c}0.673^{* * *} \\
(0.10)\end{array}$ & $\begin{array}{c}0.336^{* * *} \\
(0.10)\end{array}$ & $\begin{array}{c}0.288^{\star * *} \\
(0.06)\end{array}$ & $\begin{array}{c}0.285^{\text {***}} \\
(0.06)\end{array}$ \\
\hline Comlang & $\begin{array}{c}0.367^{\star * *} \\
(0.05)\end{array}$ & $\begin{array}{c}0.491^{\star * *} \\
(0.05)\end{array}$ & & & $\begin{array}{c}0.357^{\star \star \star} \\
(0.05)\end{array}$ & $\begin{array}{c}0.490^{\star * *} \\
(0.05)\end{array}$ & & & $\begin{array}{c}0.368^{\star * *} \\
(0.05)\end{array}$ & $\begin{array}{c}0.491^{* * *} \\
(0.05)\end{array}$ & & \\
\hline Comborder & $\begin{array}{c}0.668^{\star * *} \\
(0.12)\end{array}$ & $\begin{array}{c}0.657^{\star * *} \\
(0.13)\end{array}$ & & & $\begin{array}{c}0.661^{\text {***}} \\
(0.12)\end{array}$ & $\begin{array}{c}0.659^{* * *} \\
(0.13)\end{array}$ & & & $\begin{array}{c}0.664^{* * *} \\
(0.12)\end{array}$ & $\begin{array}{c}0.657^{* * *} \\
(0.13)\end{array}$ & & \\
\hline Landl & $\begin{array}{c}-0.398^{* * *} \\
(0.04)\end{array}$ & $\begin{array}{l}0.381 \\
(0.35)\end{array}$ & & & $\begin{array}{c}-0.393^{\star * *} \\
(0.04)\end{array}$ & $\begin{array}{l}0.353 \\
(0.35)\end{array}$ & & & $\begin{array}{c}-0.398^{* * *} \\
(0.04)\end{array}$ & $\begin{array}{l}0.396 \\
(0.35)\end{array}$ & & \\
\hline Island & $\begin{array}{c}0.562^{* * *} \\
(0.06)\end{array}$ & $\begin{array}{c}1.973^{\star * *} \\
(0.31)\end{array}$ & & & $\begin{array}{c}0.475^{\star \star *} \\
(0.06)\end{array}$ & $\begin{array}{c}1.998^{* \star *} \\
(0.31)\end{array}$ & & & $\begin{array}{c}0.547^{\star \star *} \\
(0.06)\end{array}$ & $\begin{array}{c}1.988^{* * *} \\
(0.31)\end{array}$ & & \\
\hline Lareap & $\begin{array}{c}-0.107^{\star * *} \\
(0.01)\end{array}$ & $\begin{array}{c}0.557^{\star \star *} \\
(0.03)\end{array}$ & & & $\begin{array}{c}-0.101^{\star * *} \\
(0.01)\end{array}$ & $\begin{array}{c}0.551^{* * *} \\
(0.03)\end{array}$ & & & $\begin{array}{c}-0.106^{\star * *} \\
(0.01)\end{array}$ & $\begin{array}{c}0.555^{\star * *} \\
(0.03)\end{array}$ & & \\
\hline Comcol & $\begin{array}{c}1.075^{\star * *} \\
(0.09)\end{array}$ & $\begin{array}{c}1.052^{\star * *} \\
(0.08)\end{array}$ & & & $\begin{array}{c}1.064^{* * *} \\
(0.09)\end{array}$ & $\begin{array}{c}1.051^{* * *} \\
(0.08)\end{array}$ & & & $\begin{array}{c}1.071^{\text {***}} \\
(0.09)\end{array}$ & $\begin{array}{c}1.052^{* * *} \\
(0.08)\end{array}$ & & \\
\hline Curcol & $\begin{array}{c}-2.653^{* * *} \\
(0.14)\end{array}$ & $\begin{array}{c}-2.404^{\star \star *} \\
(0.19)\end{array}$ & $\begin{array}{c}-2.740^{* * *} \\
(0.03)\end{array}$ & $\begin{array}{c}-1.869^{* * *} \\
(0.03)\end{array}$ & $\begin{array}{c}-2.589^{\star \star *} \\
(0.14)\end{array}$ & $\begin{array}{c}-2.370^{* * *} \\
(0.19)\end{array}$ & $\begin{array}{c}-2.709^{* * *} \\
(0.03)\end{array}$ & $\begin{array}{c}-2.215^{\star * *} \\
(0.03)\end{array}$ & $\begin{array}{c}-2.641^{\star * *} \\
(0.14)\end{array}$ & $\begin{array}{c}-2.402^{* \star *} \\
(0.19)\end{array}$ & $\begin{array}{c}-2.739^{* * *} \\
(0.03)\end{array}$ & $\begin{array}{c}-2.514^{* * *} \\
(0.03)\end{array}$ \\
\hline Evercol & $\begin{array}{c}1.219^{* * *} \\
(0.14)\end{array}$ & $\begin{array}{c}1.213^{* * *} \\
(0.14)\end{array}$ & & & $\begin{array}{c}1.248^{* * *} \\
(0.14)\end{array}$ & $\begin{array}{c}1.214^{\star * *} \\
(0.14)\end{array}$ & & & $\begin{array}{c}1.221^{* \star *} \\
(0.14)\end{array}$ & $\begin{array}{c}1.214^{* * *} \\
(0.14)\end{array}$ & & \\
\hline Constant & $\begin{array}{c}-22.41^{* * *} \\
(0.47)\end{array}$ & $\begin{array}{c}13.02^{* * *} \\
(1.66)\end{array}$ & $\begin{array}{l}0.950 \\
(1.85)\end{array}$ & $\begin{array}{l}1.020 \\
(1.85)\end{array}$ & $\begin{array}{c}-22.54^{\star \star *} \\
(0.47)\end{array}$ & $\begin{array}{c}12.650^{* * *} \\
(1.66)\end{array}$ & $\begin{array}{l}0.403 \\
(1.85)\end{array}$ & $\begin{array}{l}0.612 \\
(1.85)\end{array}$ & $\begin{array}{c}-22.47^{\star * *} \\
(0.47)\end{array}$ & $\begin{array}{c}12.88^{* * *} \\
(1.66)\end{array}$ & $\begin{array}{l}0.776 \\
(1.85)\end{array}$ & $\begin{array}{l}0.876 \\
(1.85)\end{array}$ \\
\hline Observations & 199,912 & 199,912 & 199,912 & 199,912 & 199,912 & 199,912 & 199,912 & 199,912 & 199,912 & 199,912 & 199,912 & 199,912 \\
\hline Number of pairid & & & 9,024 & 9,024 & & & 9,024 & & & & 9,024 & \\
\hline R-squared & 0.671 & 0.744 & 0.172 & 0.258 & 0.670 & 0.744 & 0.172 & 0.258 & 0.671 & 0.744 & 0.172 & 0.258 \\
\hline R2-within & & & 0.172 & 0.258 & & & 0.172 & 0.258 & & & 0.172 & 0.258 \\
\hline R2-between & & & 0.450 & 0.465 & & & 0.442 & 0.453 & & & 0.448 & 0.472 \\
\hline R2-overall & & & 0.351 & 0.372 & & & 0.346 & 0.369 & & & 0.350 & 0.381 \\
\hline Hausman test ( $p$-value) & & & 0.000 & 0.000 & & & 0.000 & 0.000 & & & 0.000 & 0.000 \\
\hline $\begin{array}{l}\text { Source: Authors' calculations } \\
\text { Dependent variable is log of } \\
\text { Robust clustered standard er } \\
{ }^{* * *} \text {, }{ }^{* *} \text { and }{ }^{*} \text { indicate significa } \\
{ }^{a} \text { CFE= country-fixed effects } \\
{ }^{\circ} \text { Sum of magnitude scores } \\
{ }^{1} \text { Sum of average of neighbo } \\
\text { < Sum of average of neighbo } \\
{ }^{5} \text { Sum of average of neighbo }\end{array}$ & $\begin{array}{l}\text { at the } 1 \% \text {, } \\
\text { uded; CPFE } \\
\text { Il types of c } \\
\text { od magnituc } \\
\text { od magnituc } \\
\text { od magnituc }\end{array}$ & $\begin{array}{l}\text { rade. } \\
\text { heses; Time } \\
5 \% \text { and } 10 \% \\
E=\text { country-p } \\
\text { conflict (confl } \\
\text { ude scores for } \\
\text { ude scores for } \\
\text { ude scores for }\end{array}$ & $\begin{array}{l}\text { effects inclu } \\
\% \text { significanc } \\
\text { oair fixed effe } \\
\text { flict ) in the tra } \\
\text { or civil and et } \\
\text { or internation }\end{array}$ & $\begin{array}{l}\text { ded in all spe } \\
\text { ce levels, res } \\
\text { ects included; } \\
\text { ading pair. } \\
\text { hnic violence } \\
\text { al violence an }\end{array}$ & $\begin{array}{l}\text { cations. } \\
\text { tively. } \\
\text { PFE=col } \\
\text { d war ( } n c i \\
\text { var (nintcc }\end{array}$ & $\begin{array}{l}\text {-year and } \\
\text { f) for the } \\
\text { for the tre }\end{array}$ & $\begin{array}{l}\text { untry-pair } \mathrm{f} \\
\text { ding pair. } \\
\text { g pair. }\end{array}$ & d effects & ded. & & & \\
\hline
\end{tabular}


Table 5. Estimation results for border weighted conflict (world sample, 1948-2006)

\begin{tabular}{|c|c|c|c|c|c|c|}
\hline \multirow[b]{2}{*}{ Index } & \multicolumn{2}{|c|}{ Societal conflict } & \multicolumn{2}{|c|}{ International conflict } & \multicolumn{2}{|c|}{ Overall conflict } \\
\hline & Intensity $^{1}$ & Presence $^{2}$ & Intensity $^{3}$ & Presence $^{4}$ & Intensity $^{5}$ & Presence $^{6}$ \\
\hline Specification & (1) & (2) & (3) & (4) & (5) & (6) \\
\hline Neighbor at war & $\begin{array}{c}-0.032^{\star * *} \\
(0.01)\end{array}$ & $\begin{array}{c}-0.125^{\star \star \star} \\
(0.02)\end{array}$ & $\begin{array}{c}-0.058^{* * *} \\
(0.01)\end{array}$ & $\begin{array}{c}-0.236^{\star \star *} \\
(0.03)\end{array}$ & $\begin{array}{c}-0.035^{\star \star \star} \\
(0.01)\end{array}$ & $\begin{array}{c}-0.158^{\star \star \star} \\
(0.02)\end{array}$ \\
\hline War $^{\mathrm{a}, \mathrm{b}}$ & $\begin{array}{c}-0.046^{* * *} \\
(0.00)\end{array}$ & $\begin{array}{c}-0.126^{\star * \star} \\
(0.02)\end{array}$ & $\begin{array}{c}-0.044^{* * *} \\
(0.00)\end{array}$ & $\begin{array}{c}-0.124^{* * *} \\
(0.02)\end{array}$ & $\begin{array}{c}-0.044^{* * *} \\
(0.00)\end{array}$ & $\begin{array}{c}-0.122^{* * *} \\
(0.02)\end{array}$ \\
\hline Neighbor polity index & $\begin{array}{c}0.006^{* * *} \\
(0.00)\end{array}$ & $\begin{array}{c}0.005^{\star * *} \\
(0.00)\end{array}$ & $\begin{array}{c}0.006^{\star * *} \\
(0.00)\end{array}$ & $\begin{array}{c}0.005^{\star * *} \\
(0.00)\end{array}$ & $\begin{array}{c}0.005^{\star * *} \\
(0.00)\end{array}$ & $\begin{array}{c}0.005^{\star * *} \\
(0.00)\end{array}$ \\
\hline Lrgdp & $\begin{array}{c}0.402^{* \star *} \\
(0.06)\end{array}$ & $\begin{array}{c}0.414^{* * *} \\
(0.06)\end{array}$ & $\begin{array}{c}0.405^{* * *} \\
(0.06)\end{array}$ & $\begin{array}{c}0.408^{* * *} \\
(0.06)\end{array}$ & $\begin{array}{c}0.408^{* * *} \\
(0.06)\end{array}$ & $\begin{array}{c}0.425^{\star \star *} \\
(0.06)\end{array}$ \\
\hline Lrgdppc & $\begin{array}{c}-0.214^{* * *} \\
(0.06)\end{array}$ & $\begin{array}{c}-0.222^{\star * *} \\
(0.06)\end{array}$ & $\begin{array}{c}-0.218^{\star * *} \\
(0.06)\end{array}$ & $\begin{array}{c}-0.218^{* * *} \\
(0.06)\end{array}$ & $\begin{array}{c}-0.221^{* * *} \\
(0.06)\end{array}$ & $\begin{array}{c}-0.234^{\star * *} \\
(0.06)\end{array}$ \\
\hline $\mathrm{CU}$ & $\begin{array}{c}0.360^{\star \star *} \\
(0.10)\end{array}$ & $\begin{array}{c}0.347^{* * *} \\
(0.11)\end{array}$ & $\begin{array}{c}0.351^{* * *} \\
(0.11)\end{array}$ & $\begin{array}{c}0.338^{\star * *} \\
(0.11)\end{array}$ & $\begin{array}{c}0.359^{* * *} \\
(0.10)\end{array}$ & $\begin{array}{c}0.343^{* * *} \\
(0.10)\end{array}$ \\
\hline FTA & $\begin{array}{c}0.297^{\star * *} \\
(0.07)\end{array}$ & $\begin{array}{c}0.306^{* * *} \\
(0.07)\end{array}$ & $\begin{array}{c}0.291^{* * *} \\
(0.07)\end{array}$ & $\begin{array}{c}0.292^{* * *} \\
(0.07)\end{array}$ & $\begin{array}{c}0.297^{* * *} \\
(0.07)\end{array}$ & $\begin{array}{c}0.305^{\star * *} \\
(0.07)\end{array}$ \\
\hline Curcol & $\begin{array}{c}-2.764^{* * *} \\
(0.03)\end{array}$ & $\begin{array}{c}-2.837^{* * *} \\
(0.03)\end{array}$ & $\begin{array}{c}-2.741^{* * *} \\
(0.03)\end{array}$ & $\begin{array}{l}-2.790^{* * *} \\
(0.0287)\end{array}$ & $\begin{array}{c}-2.765^{\star * *} \\
(0.03)\end{array}$ & $\begin{array}{c}-2.820^{\star * *} \\
(0.03)\end{array}$ \\
\hline Constant & $\begin{array}{l}-0.228 \\
(1.94)\end{array}$ & $\begin{array}{l}-0.661 \\
(1.94)\end{array}$ & $\begin{array}{l}-0.346 \\
(1.94)\end{array}$ & $\begin{array}{l}-0.458 \\
(1.946)\end{array}$ & $\begin{array}{l}-0.414 \\
(1.94)\end{array}$ & $\begin{array}{l}-0.988 \\
(1.944)\end{array}$ \\
\hline Observations & 181,405 & 181,405 & 181,405 & 181,405 & 181,405 & 181,405 \\
\hline Number of pairid & 8,277 & 8,277 & 8,277 & 8,277 & 8,277 & 8,277 \\
\hline R2-within & 0.168 & 0.168 & 0.167 & 0.167 & 0.168 & 0.168 \\
\hline R2-between & 0.438 & 0.436 & 0.426 & 0.431 & 0.436 & 0.433 \\
\hline R2-overall & 0.349 & 0.350 & 0.339 & 0.349 & 0.349 & 0.349 \\
\hline Hausman test ( $p$-value) & 0.000 & 0.000 & 0.000 & 0.000 & 0.000 & 0.000 \\
\hline $\begin{array}{l}\text { Source: Author's calculations } \\
\text { Dependent variable is log of } \\
\text { Robust clustered standard er } \\
{ }^{* * *},{ }^{* *} \text { and }{ }^{*} \text { indicate significa } \\
\text { a Sum of magnitude scores } \\
\text { b } \text { Dummy variable equal to or } \\
{ }^{1} \text { Sum of border length weigh } \\
{ }^{2} \text { Sum of border length weigh } \\
{ }^{3} \text { Sum of border length weigh } \\
{ }^{4} \text { Sum of border length weigh } \\
{ }^{5} \text { Sum of border length weigh } \\
{ }^{6} \text { Sum of border length weigh }\end{array}$ & $\begin{array}{l}\text { bilateral trade } \\
\text { in parenthes } \\
\text { at the } 1 \%, 5^{\circ} \\
\text { I types of cor } \\
\text { at least one } \\
\text { average of } n \in \\
\text { average num } \\
\text { average of } n \in \\
\text { average num } \\
\text { average of ne } \\
\text { average num }\end{array}$ & $\begin{array}{l}\text { untry-pair and } \\
10 \% \text { significa } \\
\text { conflict) in the } \\
\text { y in the pair is } \\
\text { r magnitude } s \\
\text { neighbors in } \\
\text { magnitude s } \\
\text { neighbors in } \\
\text { nagnitude s } \\
\text { neighbors in }\end{array}$ & $\begin{array}{l}\text { ffects includ } \\
\text { vels, respecti } \\
\text { pair and nei } \\
\text { ed in any con } \\
\text { for civil and e } \\
\text { d ethnic viole } \\
\text { for internatior } \\
\text { tional violeno } \\
\text { for all types o } \\
\text { e of conflict }\end{array}$ & $\begin{array}{l}\text { all specificati } \\
\text { or at war is co } \\
\text { and neighbor } \\
\text { c violence anc } \\
\text { and war ( } w \_n \\
\text { iolence and } w \\
\text { hd war }\left(w \_n i n\right. \\
\text { nflict }\left(w \_n c o n\right. \\
\text { conflictd) for }\end{array}$ & $\begin{array}{l}\text { intensity. } \\
\text { ar is conflict } \\
\text { (w_ncivconf } \\
\text { onfd ) for the } \\
\text { vnnintconf) fo } \\
\text { d) for the pai } \\
\text { for the pair. } \\
\text { air. }\end{array}$ & $\begin{array}{l}\text { ence. } \\
\text { the pair. } \\
\text { pair. }\end{array}$ \\
\hline
\end{tabular}


Table 6. Estimation results for conflict presence (subsamples, 1948-2006)

\begin{tabular}{|c|c|c|c|c|c|c|c|c|c|}
\hline & \multicolumn{3}{|c|}{ Societal (intrastate) conflict $^{1}$} & \multicolumn{3}{|c|}{ International conflict $^{2}$} & \multicolumn{3}{|c|}{ Overall conflict ${ }^{3}$} \\
\hline $\begin{array}{l}\text { Sample } \\
\text { Specification }\end{array}$ & $\begin{array}{c}\text { High-High } \\
\text { (1) }\end{array}$ & $\begin{array}{c}\text { High-Low } \\
\text { (2) }\end{array}$ & $\begin{array}{c}\text { Low-Low } \\
\text { (3) } \\
\end{array}$ & $\begin{array}{c}\text { High-High } \\
(4) \\
\end{array}$ & $\begin{array}{c}\text { High-Low } \\
(5) \\
\end{array}$ & $\begin{array}{c}\text { Low-Low } \\
(6)\end{array}$ & $\begin{array}{c}\text { High-High } \\
(7) \\
\end{array}$ & $\begin{array}{c}\text { High-Low } \\
(8) \\
\end{array}$ & $\begin{array}{c}\text { Low-Low } \\
(9)\end{array}$ \\
\hline Neighbor at war & $\begin{array}{c}-0.150^{\star * \star} \\
(0.03)\end{array}$ & $\begin{array}{c}-0.180^{\star \star *} \\
(0.03)\end{array}$ & $\begin{array}{l}0.009 \\
(0.06)\end{array}$ & $\begin{array}{c}-0.123^{* * *} \\
(0.04)\end{array}$ & $\begin{array}{c}-0.237^{* * *} \\
(0.04)\end{array}$ & $\begin{array}{r}-0.134 \\
(0.08)\end{array}$ & $\begin{array}{c}-0.154^{\star \star *} \\
(0.03)\end{array}$ & $\begin{array}{c}-0.198^{* * *} \\
(0.03)\end{array}$ & $\begin{array}{l}0.003 \\
(0.06)\end{array}$ \\
\hline $\operatorname{War}^{a}$ & $\begin{array}{c}-0.091^{* * *} \\
(0.03)\end{array}$ & $\begin{array}{c}-0.101^{* * *} \\
(0.02)\end{array}$ & $\begin{array}{c}-0.080^{\star \star *} \\
(0.04)\end{array}$ & $\begin{array}{c}-0.092^{\star * *} \\
(0.03)\end{array}$ & $\begin{array}{c}-0.102^{\star \star *} \\
(0.02)\end{array}$ & $\begin{array}{c}-0.074^{*} \\
(0.04)\end{array}$ & $\begin{array}{c}-0.094^{\star \star *} \\
(0.03)\end{array}$ & $\begin{array}{c}-0.099^{* * *} \\
(0.02)\end{array}$ & $\begin{array}{c}-0.080^{\star *} \\
(0.04)\end{array}$ \\
\hline Neighbor polity index & $\begin{array}{c}0.014^{\star * *} \\
(0.00)\end{array}$ & $\begin{array}{l}0.003 \\
(0.00)\end{array}$ & $\begin{array}{l}-0.007 \\
(0.00)\end{array}$ & $\begin{array}{c}0.013^{* * *} \\
(0.00)\end{array}$ & $\begin{array}{l}0.002 \\
(0.00)\end{array}$ & $\begin{array}{l}-0.007 \\
(0.00)\end{array}$ & $\begin{array}{c}0.013^{* * *} \\
(0.00)\end{array}$ & $\begin{array}{l}0.003 \\
(0.00)\end{array}$ & $\begin{array}{l}-0.007 \\
(0.00)\end{array}$ \\
\hline Lrgdppc & $\begin{array}{c}0.423^{* * *} \\
(0.08)\end{array}$ & $\begin{array}{c}0.870^{* * *} \\
(0.10)\end{array}$ & $\begin{array}{c}0.602^{* *} \\
(0.23)\end{array}$ & $\begin{array}{c}0.434^{* * *} \\
(0.08)\end{array}$ & $\begin{array}{c}0.874^{* * *} \\
(0.10)\end{array}$ & $\begin{array}{c}0.610^{* * *} \\
(0.23)\end{array}$ & $\begin{array}{c}0.429^{* * *} \\
(0.08)\end{array}$ & $\begin{array}{c}0.880^{* * *} \\
(0.10)\end{array}$ & $\begin{array}{c}0.603^{* *} \\
(0.24)\end{array}$ \\
\hline Lrgdppc & $\begin{array}{c}-0.344^{\star * *} \\
(0.08)\end{array}$ & $\begin{array}{c}-0.528^{\star * \star} \\
(0.10)\end{array}$ & $\begin{array}{l}0.185 \\
(0.21)\end{array}$ & $\begin{array}{c}-0.356^{\star \star *} \\
(0.08)\end{array}$ & $\begin{array}{c}-0.533^{* * *} \\
(0.10)\end{array}$ & $\begin{array}{l}0.174 \\
(0.21)\end{array}$ & $\begin{array}{c}-0.350^{\star \star *} \\
(0.08)\end{array}$ & $\begin{array}{c}-0.540^{* * *} \\
(0.10)\end{array}$ & $\begin{array}{l}0.184 \\
(0.22)\end{array}$ \\
\hline $\mathrm{CU}$ & $\begin{array}{c}0.226^{\star * *} \\
(0.07)\end{array}$ & $\begin{array}{c}0.976^{\star * *} \\
(0.20)\end{array}$ & $\begin{array}{l}0.029 \\
(0.26)\end{array}$ & $\begin{array}{c}0.237^{\star * *} \\
(0.07)\end{array}$ & $\begin{array}{c}0.966^{\star * *} \\
(0.20)\end{array}$ & $\begin{array}{l}0.030 \\
(0.26)\end{array}$ & $\begin{array}{c}0.222^{* * *} \\
(0.07)\end{array}$ & $\begin{array}{c}0.971^{* * *} \\
(0.20)\end{array}$ & $\begin{array}{l}0.029 \\
(0.26)\end{array}$ \\
\hline FTA & $\begin{array}{c}0.392^{* * *} \\
(0.04)\end{array}$ & $\begin{array}{c}0.575^{\star *} \\
(0.22)\end{array}$ & $\begin{array}{c}0.485^{\star * *} \\
(0.15)\end{array}$ & $\begin{array}{c}0.391^{* * *} \\
(0.04)\end{array}$ & $\begin{array}{c}0.576^{\star *} \\
(0.23)\end{array}$ & $\begin{array}{c}0.476^{\star * *} \\
(0.15)\end{array}$ & $\begin{array}{c}0.389^{* * *} \\
(0.04)\end{array}$ & $\begin{array}{c}0.571^{* *} \\
(0.22)\end{array}$ & $\begin{array}{c}0.485^{\star * *} \\
(0.15)\end{array}$ \\
\hline Curcol & $\begin{array}{l}3.239 \\
(2.72)\end{array}$ & $\begin{array}{c}-2.953^{\star \star *} \\
(0.04)\end{array}$ & $\begin{array}{c}-16.430^{* *} \\
(8.31)\end{array}$ & $\begin{array}{l}2.867 \\
(2.71)\end{array}$ & $\begin{array}{c}-2.905^{\star * *} \\
(0.04)\end{array}$ & $\begin{array}{c}-16.630^{* *} \\
(8.29)\end{array}$ & $\begin{array}{l}3.088 \\
(2.71)\end{array}$ & $\begin{array}{c}-2.935^{\star * *} \\
(0.04)\end{array}$ & $\begin{array}{c}-16.470^{* *} \\
(8.33)\end{array}$ \\
\hline Constant & & $\begin{array}{c}-18.49^{* * *} \\
(3.54)\end{array}$ & & & $\begin{array}{c}-18.64^{* * *} \\
(3.55)\end{array}$ & & & $\begin{array}{c}-18.79^{* * *} \\
(3.54)\end{array}$ & \\
\hline Observations & 53,963 & 106,528 & 39,421 & 53,963 & 106,528 & 39,421 & 53,963 & 106,528 & 39,421 \\
\hline Number of pairid & 2,039 & 4,718 & 2,267 & 2,039 & 4,718 & 2,267 & 2,039 & 4,718 & 2,267 \\
\hline R2-within & 0.357 & 0.157 & 0.131 & 0.356 & 0.157 & 0.131 & 0.357 & 0.158 & 0.131 \\
\hline R2-between & 0.388 & 0.453 & 0.297 & 0.385 & 0.451 & 0.298 & 0.386 & 0.451 & 0.298 \\
\hline R2-overall & 0.345 & 0.399 & 0.249 & 0.343 & 0.396 & 0.250 & 0.345 & 0.397 & 0.250 \\
\hline $\begin{array}{l}\text { Source: Author's calculat } \\
\text { Dependent variable is lo } \\
\text { Robust clustered standar } \\
{ }^{* * *} \text {, }{ }^{* *} \text { and }{ }^{*} \text { indicate sign } \\
{ }^{a} \text { Dummy variable equal } \\
{ }^{2} \text { Sum of average numbe } \\
{ }^{2} \text { Sum of average numbe } \\
\text { s Sum of average numbe }\end{array}$ & $\begin{array}{l}\text { s. } \\
\text { real bilatera } \\
\text { rrors in pare } \\
\text { ance at the } 1 \\
\text { ne if at leas } \\
\text { neighbors i } \\
\text { neighbors i } \\
\text { neighbors i }\end{array}$ & $\begin{array}{l}\text { Il trade. } \\
\text { ntheses; co } \\
\%, 5 \% \text { and } \\
\text { one countr } \\
\text { nvolved in ci } \\
\text { n internation } \\
\text { h any type o }\end{array}$ & $\begin{array}{l}\text { ry-pair and } \\
\% \text { significa } \\
\text { the tradins } \\
\text { and ethnic } \\
\text { iolence an } \\
\text { nflict (ncol }\end{array}$ & $\begin{array}{l}\text { e effects inc } \\
\text { levels, resp } \\
\text { ir is involved } \\
\text { ence and wo } \\
\text { ar (nintconfo } \\
\text { t) for the }\end{array}$ & $\begin{array}{l}\text { luded in all sp } \\
\text { ectively. } \\
\text { in any type o } \\
\text { ar (ncivconfd) } \\
\text { ) for the tradi } \\
\text { ading pair. }\end{array}$ & $\begin{array}{l}\text { cifications. } \\
\text { conflict. } \\
\text { or the tradin } \\
\text { g pair. }\end{array}$ & & & \\
\hline
\end{tabular}


Table 7. Estimation results for conflict intensity (subsamples, 1948-2006)

\begin{tabular}{|c|c|c|c|c|c|c|c|c|c|}
\hline \multirow[b]{2}{*}{$\begin{array}{l}\text { Sample } \\
\text { Specification }\end{array}$} & \multicolumn{3}{|c|}{ Societal (intrastate) conflict $^{1}$} & \multicolumn{3}{|c|}{ International conflict ${ }^{2}$} & \multicolumn{3}{|c|}{ Overall conflict ${ }^{3}$} \\
\hline & $\begin{array}{l}\text { High-High } \\
(1)\end{array}$ & $\begin{array}{l}\text { High-Low } \\
(2)\end{array}$ & $\begin{array}{c}\text { Low-Low } \\
(3)\end{array}$ & $\begin{array}{c}\text { High-High } \\
(4)\end{array}$ & $\begin{array}{c}\text { High-Low } \\
(5)\end{array}$ & $\begin{array}{c}\text { Low-Low } \\
(6)\end{array}$ & $\begin{array}{c}\text { High-High } \\
(7)\end{array}$ & $\begin{array}{l}\text { High-Low } \\
(8) \\
\end{array}$ & $\begin{array}{c}\text { Low-Low } \\
\text { (9) }\end{array}$ \\
\hline Neighbor at war & $\begin{array}{c}-0.049^{* * *} \\
(0.01)\end{array}$ & $\begin{array}{c}-0.033^{* * *} \\
(0.01)\end{array}$ & $\begin{array}{c}-0.045^{\star *} \\
(0.02)\end{array}$ & $\begin{array}{l}-0.001 \\
(0.02)\end{array}$ & $\begin{array}{c}-0.076^{\star \star *} \\
(0.02)\end{array}$ & $\begin{array}{l}-0.025 \\
(0.03)\end{array}$ & $\begin{array}{c}-0.036^{\star * \star} \\
(0.01)\end{array}$ & $\begin{array}{c}-0.042^{* * *} \\
(0.01)\end{array}$ & $\begin{array}{c}-0.040^{* * *} \\
(0.02)\end{array}$ \\
\hline War $^{a}$ & $\begin{array}{c}-0.040^{\star * *} \\
(0.01)\end{array}$ & $\begin{array}{c}-0.036^{\star \star *} \\
(0.01)\end{array}$ & $\begin{array}{l}-0.014 \\
(0.01)\end{array}$ & $\begin{array}{c}-0.042^{* * *} \\
(0.01)\end{array}$ & $\begin{array}{c}-0.035^{\star \star \star} \\
(0.01)\end{array}$ & $\begin{array}{c}-0.017^{*} \\
(0.01)\end{array}$ & $\begin{array}{c}-0.038^{\star * *} \\
(0.01)\end{array}$ & $\begin{array}{c}-0.033^{* * *} \\
(0.01)\end{array}$ & $\begin{array}{l}-0.013 \\
(0.01)\end{array}$ \\
\hline Neighbor polity index & $\begin{array}{c}0.014^{* * *} \\
(0.00)\end{array}$ & $\begin{array}{l}0.003 \\
(0.00)\end{array}$ & $\begin{array}{l}-0.007 \\
(0.00)\end{array}$ & $\begin{array}{c}0.013^{* * *} \\
(0.00)\end{array}$ & $\begin{array}{l}0.003 \\
(0.00)\end{array}$ & $\begin{array}{l}-0.006 \\
(0.00)\end{array}$ & $\begin{array}{c}0.013^{* * *} \\
(0.00)\end{array}$ & $\begin{array}{l}0.003 \\
(0.00)\end{array}$ & $\begin{array}{l}-0.006 \\
(0.00)\end{array}$ \\
\hline Lrgdppc & $\begin{array}{c}0.409^{* * *} \\
(0.08)\end{array}$ & $\begin{array}{c}0.842^{* \star *} \\
(0.10)\end{array}$ & $\begin{array}{c}0.580^{\star *} \\
(0.23)\end{array}$ & $\begin{array}{c}0.434^{* * *} \\
(0.08)\end{array}$ & $\begin{array}{c}0.871^{* * *} \\
(0.10)\end{array}$ & $\begin{array}{c}0.589^{* *} \\
(0.23)\end{array}$ & $\begin{array}{c}0.419^{* * *} \\
(0.08)\end{array}$ & $\begin{array}{c}0.843^{* * *} \\
(0.10)\end{array}$ & $\begin{array}{c}0.589^{* *} \\
(0.23)\end{array}$ \\
\hline Lrgdppc & $\begin{array}{c}-0.331^{\star * *} \\
(0.08)\end{array}$ & $\begin{array}{c}-0.504^{\star \star \star} \\
(0.10)\end{array}$ & $\begin{array}{l}0.202 \\
(0.21)\end{array}$ & $\begin{array}{c}-0.355^{\star * *} \\
(0.08)\end{array}$ & $\begin{array}{c}-0.534^{* * *} \\
(0.10)\end{array}$ & $\begin{array}{l}0.191 \\
(0.21)\end{array}$ & $\begin{array}{c}-0.342^{\star \star \star} \\
(0.08)\end{array}$ & $\begin{array}{c}-0.505^{\star * *} \\
(0.10)\end{array}$ & $\begin{array}{l}0.192 \\
(0.21)\end{array}$ \\
\hline $\mathrm{CU}$ & $\begin{array}{c}0.242^{* * *} \\
(0.07)\end{array}$ & $\begin{array}{c}0.988^{* * *} \\
(0.20)\end{array}$ & $\begin{array}{l}0.001 \\
(0.26)\end{array}$ & $\begin{array}{c}0.246^{\star * *} \\
(0.07)\end{array}$ & $\begin{array}{c}0.977^{* * *} \\
(0.20)\end{array}$ & $\begin{array}{l}0.018 \\
(0.26)\end{array}$ & $\begin{array}{c}0.244^{* * *} \\
(0.07)\end{array}$ & $\begin{array}{c}0.988^{* * *} \\
(0.20)\end{array}$ & $\begin{array}{l}0.005 \\
(0.26)\end{array}$ \\
\hline FTA & $\begin{array}{c}0.394^{* * *} \\
(0.04)\end{array}$ & $\begin{array}{c}0.576^{* *} \\
(0.22)\end{array}$ & $\begin{array}{c}0.462^{* * *} \\
(0.15)\end{array}$ & $\begin{array}{c}0.393^{* * *} \\
(0.04)\end{array}$ & $\begin{array}{c}0.579^{* * *} \\
(0.23)\end{array}$ & $\begin{array}{c}0.465^{\star * *} \\
(0.15)\end{array}$ & $\begin{array}{c}0.394^{* * *} \\
(0.04)\end{array}$ & $\begin{array}{c}0.575^{\star *} \\
(0.22)\end{array}$ & $\begin{array}{c}0.456^{* * *} \\
(0.15)\end{array}$ \\
\hline Curcol & & $\begin{array}{c}-2.882^{* * *} \\
(0.04)\end{array}$ & & & $\begin{array}{c}-2.856^{\star * *} \\
(0.04)\end{array}$ & & & $\begin{array}{c}-2.885^{\star * *} \\
(0.04)\end{array}$ & \\
\hline Constant & $\begin{array}{l}3.716 \\
(2.71)\end{array}$ & $\begin{array}{c}-17.530^{\star \star *} \\
(3.56)\end{array}$ & $\begin{array}{c}-15.570^{*} \\
(8.31)\end{array}$ & $\begin{array}{l}2.869 \\
(2.71)\end{array}$ & $\begin{array}{c}-18.510^{\star * *} \\
(3.54)\end{array}$ & $\begin{array}{c}-15.900^{*} \\
(8.32)\end{array}$ & $\begin{array}{l}3.394 \\
(2.70)\end{array}$ & $\begin{array}{c}-17.510^{\star * *} \\
(3.55)\end{array}$ & $\begin{array}{c}-15.840^{*} \\
(8.31)\end{array}$ \\
\hline Observations & 53,963 & 106,528 & 39,421 & 53,963 & 106,528 & 39,421 & 53,963 & 106,528 & 39,421 \\
\hline Number of pairid & 2,039 & 4,718 & 2,267 & 2,039 & 4,718 & 2,267 & 2,039 & 4,718 & 2,267 \\
\hline R2-overall & 0.341 & 0.400 & 0.241 & 0.347 & 0.397 & 0.245 & 0.343 & 0.399 & 0.243 \\
\hline R2-within & 0.358 & 0.158 & 0.131 & 0.357 & 0.158 & 0.131 & 0.358 & 0.158 & 0.131 \\
\hline R2-between & 0.388 & 0.456 & 0.286 & 0.390 & 0.451 & 0.292 & 0.388 & 0.455 & 0.288 \\
\hline $\begin{array}{l}\text { Source: Author's calculati } \\
\text { Dependent variable is log } \\
\text { Robust clustered standar } \\
\text { *** }{ }^{* *} \text { and }{ }^{*} \text { indicate signi } \\
{ }^{a} \text { Sum of magnitude score } \\
{ }^{1} \text { Sum of average of neigh } \\
\text { ' Sum of average of neigh } \\
{ }^{\circ} \text { Sum of average of neigh }\end{array}$ & $\begin{array}{l}\text { rrors in par } \\
\text { ance at the } \\
\text { or all types } \\
\text { rhood mag } \\
\text { rhood mag } \\
\text { rhood mag }\end{array}$ & $\begin{array}{l}\text { ntheses; cou } \\
\%, 5 \% \text { and } 1 \\
\text { f conflict (co } \\
\text { itude scores } \\
\text { itude scores } \\
\text { itude scores }\end{array}$ & $\begin{array}{l}\text {-pair and } \\
\text { significa } \\
t \text { ) in the } \\
\text { civil and } \\
\text { nternatic }\end{array}$ & $\begin{array}{l}\text { ffects incl } \\
\text { vels, respe } \\
\text { pair. } \\
\text { violence a } \\
\text { lence and } \\
\text { flict } \text { (nconf }\end{array}$ & $\begin{array}{l}\mathrm{d} \text { in all sp } \\
\text { ely. } \\
\text { war (ncive } \\
\text { r (nintcont }\end{array}$ & or the t & air. & & \\
\hline
\end{tabular}


Table 8. Estimation results for border weighted conflict presence (subsamples, 1948-2006)

\begin{tabular}{|c|c|c|c|c|c|c|c|c|c|}
\hline & \multicolumn{3}{|c|}{ Societal (intrastate) conflict $^{1}$} & \multicolumn{3}{|c|}{ International conflict ${ }^{2}$} & \multicolumn{3}{|c|}{ Overall conflict $^{3}$} \\
\hline $\begin{array}{l}\text { Sample } \\
\text { Specification }\end{array}$ & $\begin{array}{c}\text { High-High } \\
(1) \\
\end{array}$ & $\begin{array}{l}\text { High-Low } \\
(2) \\
\end{array}$ & $\begin{array}{c}\text { Low-Low } \\
\text { (3) } \\
\end{array}$ & $\begin{array}{c}\text { High-High } \\
(4) \\
\end{array}$ & $\begin{array}{l}\text { High-Low } \\
(5) \\
\end{array}$ & $\begin{array}{c}\text { Low-Low } \\
(6)\end{array}$ & $\begin{array}{c}\text { High-High } \\
(7) \\
\end{array}$ & $\begin{array}{c}\text { High-Low } \\
(8) \\
\end{array}$ & $\begin{array}{c}\text { Low-Low } \\
(9)\end{array}$ \\
\hline Neighbor at war & $\begin{array}{c}-0.128^{* * *} \\
(0.04)\end{array}$ & $\begin{array}{c}-0.117^{* * *} \\
(0.03)\end{array}$ & $\begin{array}{l}-0.065 \\
(0.05)\end{array}$ & $\begin{array}{c}-0.153^{\star * \star} \\
(0.04)\end{array}$ & $\begin{array}{c}-0.246^{\star * \star} \\
(0.05)\end{array}$ & $\begin{array}{l}-0.156^{*} \\
(0.08)\end{array}$ & $\begin{array}{c}-0.149^{* * *} \\
(0.03)\end{array}$ & $\begin{array}{c}-0.158^{* * *} \\
(0.03)\end{array}$ & $\begin{array}{l}-0.065 \\
(0.05)\end{array}$ \\
\hline War $^{a}$ & $\begin{array}{c}-0.083^{* * *} \\
(0.03)\end{array}$ & $\begin{array}{c}-0.101^{* * *} \\
(0.02)\end{array}$ & $\begin{array}{l}-0.04 \\
(0.04)\end{array}$ & $\begin{array}{c}-0.084^{* * *} \\
(0.03)\end{array}$ & $\begin{array}{c}-0.097^{\star * *} \\
(0.02)\end{array}$ & $\begin{array}{l}-0.038 \\
(0.04)\end{array}$ & $\begin{array}{c}-0.085^{\star * *} \\
(0.03)\end{array}$ & $\begin{array}{c}-0.098^{* * *} \\
(0.02)\end{array}$ & $\begin{array}{r}-0.039 \\
(0.04)\end{array}$ \\
\hline Neighbor polity index & $\begin{array}{c}0.017^{\star \star \star} \\
(0.00)\end{array}$ & $\begin{array}{l}0.006^{\star *} \\
(0.00)\end{array}$ & $\begin{array}{c}-0.008^{*} \\
(0.00)\end{array}$ & $\begin{array}{c}0.016^{\star \star *} \\
(0.00)\end{array}$ & $\begin{array}{c}0.006^{\star *} \\
(0.00)\end{array}$ & $\begin{array}{c}-0.009^{*} \\
(0.00)\end{array}$ & $\begin{array}{c}0.016^{\star * *} \\
(0.00)\end{array}$ & $\begin{array}{l}0.006^{\star *} \\
(0.00)\end{array}$ & $\begin{array}{c}-0.008^{*} \\
(0.00)\end{array}$ \\
\hline Lrgdppc & $\begin{array}{c}0.446^{\star * *} \\
(0.09)\end{array}$ & $\begin{array}{c}0.879 * * * \\
(0.11)\end{array}$ & $\begin{array}{l}0.468^{*} \\
(0.24)\end{array}$ & $\begin{array}{c}0.451^{* * *} \\
(0.09)\end{array}$ & $\begin{array}{c}0.877^{* * *} \\
(0.11)\end{array}$ & $\begin{array}{l}0.457^{*} \\
(0.24)\end{array}$ & $\begin{array}{c}0.451^{* * *} \\
(0.09)\end{array}$ & $\begin{array}{c}0.890^{* * *} \\
(0.11)\end{array}$ & $\begin{array}{l}0.473^{*} \\
(0.24)\end{array}$ \\
\hline Lrgdppc & $\begin{array}{c}-0.380^{* \star *} \\
(0.09)\end{array}$ & $\begin{array}{c}-0.496^{\star * *} \\
(0.11)\end{array}$ & $\begin{array}{l}0.338 \\
(0.22)\end{array}$ & $\begin{array}{c}-0.386^{* * *} \\
(0.09)\end{array}$ & $\begin{array}{c}-0.497^{\star * *} \\
(0.11)\end{array}$ & $\begin{array}{l}0.347 \\
(0.22)\end{array}$ & $\begin{array}{c}-0.387^{\star \star \star} \\
(0.09)\end{array}$ & $\begin{array}{c}-0.509^{* * *} \\
(0.11)\end{array}$ & $\begin{array}{l}0.332 \\
(0.22)\end{array}$ \\
\hline $\mathrm{CU}$ & $\begin{array}{c}0.250^{* * *} \\
(0.07)\end{array}$ & $\begin{array}{c}0.986^{* * *} \\
(0.19)\end{array}$ & $\begin{array}{l}-0.005 \\
(0.29)\end{array}$ & $\begin{array}{c}0.243^{\star * \star} \\
(0.07)\end{array}$ & $\begin{array}{c}0.977^{\star \star *} \\
(0.19)\end{array}$ & $\begin{array}{l}-0.006 \\
(0.29)\end{array}$ & $\begin{array}{c}0.241^{* * *} \\
(0.07)\end{array}$ & $\begin{array}{c}0.977^{\star * *} \\
(0.19)\end{array}$ & $\begin{array}{l}-0.006 \\
(0.29)\end{array}$ \\
\hline FTA & $\begin{array}{c}0.429^{\star \star *} \\
(0.05)\end{array}$ & $\begin{array}{c}0.581^{\star *} \\
(0.24)\end{array}$ & $\begin{array}{c}0.485^{\star \star \star} \\
(0.15)\end{array}$ & $\begin{array}{c}0.419^{\star \star \star} \\
(0.05)\end{array}$ & $\begin{array}{c}0.578^{\star \star} \\
(0.24)\end{array}$ & $\begin{array}{c}0.472^{\star \star \star} \\
(0.15)\end{array}$ & $\begin{array}{c}0.426^{\star \star \star} \\
(0.05)\end{array}$ & $\begin{array}{c}0.582^{\star *} \\
(0.24)\end{array}$ & $\begin{array}{c}0.481^{\text {** }} \\
(0.15)\end{array}$ \\
\hline Curcol & & $\begin{array}{c}-2.966^{\star * *} \\
(0.04)\end{array}$ & & & $\begin{array}{c}-2.919^{\star \star *} \\
(0.04)\end{array}$ & & & $\begin{array}{c}-2.950^{* * *} \\
(0.04)\end{array}$ & \\
\hline Constant & $\begin{array}{l}2.609 \\
(2.91)\end{array}$ & $\begin{array}{c}-19.51^{* \star *} \\
(3.84)\end{array}$ & $\begin{array}{c}-12.110 \\
(8.64)\end{array}$ & $\begin{array}{l}2.445 \\
(2.90)\end{array}$ & $\begin{array}{c}-19.42^{* * *} \\
(3.84)\end{array}$ & $\begin{array}{c}-11.700 \\
(8.60)\end{array}$ & $\begin{array}{l}2.458 \\
(2.90)\end{array}$ & $\begin{array}{c}-19.82^{* * *} \\
(3.83)\end{array}$ & $\begin{array}{c}-12.230 \\
(8.65)\end{array}$ \\
\hline Observations & 47,290 & 96,581 & 37,534 & 47,290 & 96,581 & 37,534 & 47,290 & 96,581 & 37,534 \\
\hline Number of pairid & 1,793 & 4,311 & 2,173 & 1,793 & 4,311 & 2,173 & 1,793 & 4,311 & 2,173 \\
\hline R2-within & 0.341 & 0.157 & 0.135 & 0.341 & 0.157 & 0.135 & 0.342 & 0.157 & 0.135 \\
\hline R2-between & 0.395 & 0.452 & 0.248 & 0.388 & 0.449 & 0.243 & 0.394 & 0.450 & 0.250 \\
\hline R2-overall & 0.354 & 0.398 & 0.209 & 0.349 & 0.396 & 0.205 & 0.355 & 0.398 & 0.210 \\
\hline 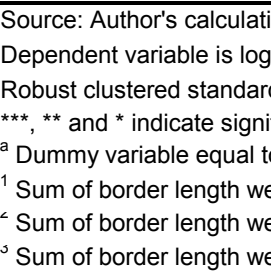 & $\begin{array}{l}\text { real bilater } \\
\text { rors in pare } \\
\text { ince at the } \\
\text { ne if at leas } \\
\text { ited averag } \\
\text { ited averag } \\
\text { ited averag }\end{array}$ & $\begin{array}{l}\text { ade. } \\
\text { leses; cou } \\
5 \% \text { and } 1 \\
\text { he country } \\
\text { umber of } n \\
\text { umber of } n\end{array}$ & $\begin{array}{l}\text {-pair and } \\
\text { significan } \\
\text { ne trading } \\
\text { nbors invo } \\
\text { abors in in }\end{array}$ & $\begin{array}{l}\text { effects inc } \\
\text { evels, resp } \\
\text { is involve } \\
\text { in civil an } \\
\text { ational vio }\end{array}$ & $\begin{array}{l}\text { ded in all s } \\
\text { ctively. } \\
n \text { any type } \\
\text { ethnic viole } \\
\text { nce and wa }\end{array}$ & $\begin{array}{l}\text { ications. } \\
\text { nflict. } \\
\text { and war ( } v \\
\text { nintconfd }\end{array}$ & $\begin{array}{l}\text { vconfd) } \\
\text { he tradi }\end{array}$ & $\begin{array}{l}\text { e tradir } \\
\text { ir. }\end{array}$ & \\
\hline
\end{tabular}


Table 9. Estimation results for border weighted conflict intensity (subsamples, 1948-2006)

\begin{tabular}{|c|c|c|c|c|c|c|c|c|c|}
\hline & \multicolumn{3}{|c|}{ Societal (intrastate) conflict ${ }^{1}$} & \multicolumn{3}{|c|}{ International conflict ${ }^{2}$} & \multicolumn{3}{|c|}{ Overall conflict ${ }^{3}$} \\
\hline $\begin{array}{l}\text { Sample } \\
\text { Specification }\end{array}$ & $\begin{array}{c}\text { High-High } \\
\text { (1) }\end{array}$ & $\begin{array}{c}\text { High-Low } \\
\text { (2) }\end{array}$ & $\begin{array}{c}\text { Low-Low } \\
\text { (3) }\end{array}$ & $\begin{array}{c}\text { High-High } \\
(4)\end{array}$ & $\begin{array}{c}\text { High-Low } \\
\text { (5) }\end{array}$ & $\begin{array}{c}\text { Low-Low } \\
(6)\end{array}$ & $\begin{array}{c}\text { High-High } \\
(7)\end{array}$ & $\begin{array}{c}\text { High-Low } \\
(8)\end{array}$ & $\begin{array}{c}\text { Low-Low } \\
\text { (9) }\end{array}$ \\
\hline Neighbor at war & $\begin{array}{c}-0.053^{\star * *} \\
(0.01)\end{array}$ & $\begin{array}{c}-0.019^{* \star *} \\
(0.01)\end{array}$ & $\begin{array}{c}-0.042^{* * *} \\
(0.01)\end{array}$ & $\begin{array}{l}-0.025 \\
(0.02)\end{array}$ & $\begin{array}{c}-0.068^{\star * *} \\
(0.02)\end{array}$ & $\begin{array}{r}-0.029 \\
(0.03)\end{array}$ & $\begin{array}{c}-0.041^{* * *} \\
(0.01)\end{array}$ & $\begin{array}{c}-0.026^{\star * *} \\
(0.01)\end{array}$ & $\begin{array}{c}-0.040^{* * *} \\
(0.01)\end{array}$ \\
\hline War $^{a}$ & $\begin{array}{c}-0.036^{\star * *} \\
(0.01)\end{array}$ & $\begin{array}{c}-0.042^{* \star *} \\
(0.01)\end{array}$ & $\begin{array}{r}-0.012 \\
(0.01)\end{array}$ & $\begin{array}{c}-0.037^{* * *} \\
(0.01)\end{array}$ & $\begin{array}{c}-0.039^{* * *} \\
(0.01)\end{array}$ & $\begin{array}{r}-0.011 \\
(0.01)\end{array}$ & $\begin{array}{c}-0.035^{* * *} \\
(0.01)\end{array}$ & $\begin{array}{c}-0.040^{\star * *} \\
(0.01)\end{array}$ & $\begin{array}{l}-0.010 \\
(0.01)\end{array}$ \\
\hline Neighbor polity index & $\begin{array}{c}0.016^{* * *} \\
(0.00)\end{array}$ & $\begin{array}{c}0.006^{* *} \\
(0.00)\end{array}$ & $\begin{array}{c}-0.009^{*} \\
(0.00)\end{array}$ & $\begin{array}{c}0.016^{* * *} \\
(0.00)\end{array}$ & $\begin{array}{c}0.006^{* *} \\
(0.00)\end{array}$ & $\begin{array}{r}-0.008 \\
(0.00)\end{array}$ & $\begin{array}{c}0.016^{\star * *} \\
(0.00)\end{array}$ & $\begin{array}{c}0.006^{\star *} \\
(0.00)\end{array}$ & $\begin{array}{c}-0.009^{*} \\
(0.00)\end{array}$ \\
\hline Lrgdppc & $\begin{array}{c}0.433^{* * *} \\
(0.09)\end{array}$ & $\begin{array}{c}0.865^{\star * *} \\
(0.11)\end{array}$ & $\begin{array}{c}0.479^{\star *} \\
(0.24)\end{array}$ & $\begin{array}{c}0.452^{* * *} \\
(0.09)\end{array}$ & $\begin{array}{c}0.877^{* * *} \\
(0.11)\end{array}$ & $\begin{array}{l}0.446^{*} \\
(0.24)\end{array}$ & $\begin{array}{c}0.441^{* * *} \\
(0.09)\end{array}$ & $\begin{array}{c}0.867^{\star * *} \\
(0.11)\end{array}$ & $\begin{array}{c}0.487^{* *} \\
(0.24)\end{array}$ \\
\hline Lrgdppc & $\begin{array}{c}-0.368^{\star * *} \\
(0.09)\end{array}$ & $\begin{array}{c}-0.490^{\star * *} \\
(0.11)\end{array}$ & $\begin{array}{l}0.324 \\
(0.22)\end{array}$ & $\begin{array}{c}-0.387^{* * *} \\
(0.09)\end{array}$ & $\begin{array}{c}-0.502^{* * *} \\
(0.11)\end{array}$ & $\begin{array}{l}0.355 \\
(0.22)\end{array}$ & $\begin{array}{c}-0.377^{* * *} \\
(0.09)\end{array}$ & $\begin{array}{c}-0.493^{* * *} \\
(0.11)\end{array}$ & $\begin{array}{l}0.315 \\
(0.22)\end{array}$ \\
\hline $\mathrm{CU}$ & $\begin{array}{c}0.273^{* * *} \\
(0.07)\end{array}$ & $\begin{array}{c}0.996^{\star * *} \\
(0.19)\end{array}$ & $\begin{array}{l}-0.018 \\
(0.29)\end{array}$ & $\begin{array}{c}0.257^{* \star *} \\
(0.07)\end{array}$ & $\begin{array}{c}0.988^{* * *} \\
(0.19)\end{array}$ & $\begin{array}{l}-0.009 \\
(0.29)\end{array}$ & $\begin{array}{c}0.267^{* * *} \\
(0.07)\end{array}$ & $\begin{array}{c}0.993^{\star * *} \\
(0.19)\end{array}$ & $\begin{array}{l}-0.018 \\
(0.29)\end{array}$ \\
\hline FTA & $\begin{array}{c}0.435^{\star * *} \\
(0.05)\end{array}$ & $\begin{array}{c}0.580^{\star *} \\
(0.24)\end{array}$ & $\begin{array}{c}0.463^{* * *} \\
(0.15)\end{array}$ & $\begin{array}{c}0.423^{* * *} \\
(0.05)\end{array}$ & $\begin{array}{c}0.579^{\star *} \\
(0.24)\end{array}$ & $\begin{array}{c}0.469^{* * *} \\
(0.15)\end{array}$ & $\begin{array}{c}0.431^{* * *} \\
(0.05)\end{array}$ & $\begin{array}{c}0.582^{* *} \\
(0.24)\end{array}$ & $\begin{array}{c}0.455^{\star * *} \\
(0.15)\end{array}$ \\
\hline Curcol & & $\begin{array}{c}-2.890^{\star * *} \\
(0.04)\end{array}$ & & & $\begin{array}{c}-2.876^{\star * *} \\
(0.04)\end{array}$ & & & $\begin{array}{c}-2.894^{\star * *} \\
(0.04)\end{array}$ & \\
\hline Constant & $\begin{array}{l}3.053 \\
(2.89)\end{array}$ & $\begin{array}{c}-18.98^{\star * \star} \\
(3.84)\end{array}$ & $\begin{array}{c}-12.400 \\
(8.61)\end{array}$ & $\begin{array}{l}2.411 \\
(2.90)\end{array}$ & $\begin{array}{c}-19.35^{\star \star *} \\
(3.83)\end{array}$ & $\begin{array}{c}-11.290 \\
(8.62)\end{array}$ & $\begin{array}{l}2.804 \\
(2.88)\end{array}$ & $\begin{array}{c}-19.01^{* * *} \\
(3.83)\end{array}$ & $\begin{array}{c}-12.620 \\
(8.61)\end{array}$ \\
\hline Observations & 47,290 & 96,581 & 37,534 & 47,290 & 96,581 & 37,534 & 47,290 & 96,581 & 37,534 \\
\hline Number of pairid & 1,793 & 4,311 & 2,173 & 1,793 & 4,311 & 2,173 & 1,793 & 4,311 & 2,173 \\
\hline R2-within & 0.343 & 0.158 & 0.135 & 0.342 & 0.158 & 0.135 & 0.343 & 0.158 & 0.136 \\
\hline R2-between & 0.399 & 0.454 & 0.246 & 0.392 & 0.450 & 0.238 & 0.397 & 0.454 & 0.248 \\
\hline R2-overall & 0.355 & 0.400 & 0.209 & 0.351 & 0.397 & 0.200 & 0.355 & 0.400 & 0.211 \\
\hline $\begin{array}{l}\text { Source: Author's calculat } \\
\text { Dependent variable is log } \\
\text { Robust clustered standar } \\
\text { *** }{ }^{* *} \text { and }{ }^{*} \text { indicate sign } \\
{ }^{a} \text { Sum of magnitude scor } \\
{ }^{1} \text { Sum of border length w } \\
\text { ¿ Sum of border length w } \\
\text { } \text { Sum of border length we }\end{array}$ & $\begin{array}{l}\text { real bilater } \\
\text { ancers in par } \\
\text { for all types } \\
\text { hted averas } \\
\text { hted averas } \\
\text { hted averas }\end{array}$ & $\begin{array}{l}\text { Il trade. } \\
\text { entheses; cou } \\
1 \%, 5 \% \text { and } \\
\text { of conflict ( } c 0 \\
\text { e of neighbor } \\
\text { e of neighbor } \\
\text { e of neighbor }\end{array}$ & $\begin{array}{l}\text { ntry-pair ar } \\
10 \% \text { signific } \\
\text { nflict ) in th } \\
\text { hood magn } \\
\text { hood magn } \\
\text { hood magn }\end{array}$ & $\begin{array}{l}\text { me effects } \\
\text { a levels, re } \\
\text { e sing pair. } \\
\text { e scores fo } \\
\text { e scores fo } \\
\text { e scores fo }\end{array}$ & $\begin{array}{l}\text { cluded in a } \\
\text { pectively. } \\
\text { civil and et } \\
\text { internation }\end{array}$ & $\begin{array}{l}\text { violence } \\
\text { plence ar }\end{array}$ & (w_nint & for the tr & $\begin{array}{l}\text { ng pair. } \\
\text { pair. }\end{array}$ \\
\hline
\end{tabular}


Table 10. Estimation results for regional conflict duration, 1948-2006

\begin{tabular}{|c|c|c|c|c|c|c|}
\hline \multirow[b]{2}{*}{$\begin{array}{l}\text { Sample } \\
\text { Specification }\end{array}$} & \multirow{2}{*}{$\begin{array}{c}\text { Societal conflict } \\
\text { World } \\
(1) \\
\end{array}$} & \multirow{2}{*}{$\begin{array}{c}\text { International conflict } \\
\text { World } \\
(2) \\
\end{array}$} & \multicolumn{4}{|c|}{ All conflict } \\
\hline & & & $\begin{array}{c}\text { World } \\
(3) \\
\end{array}$ & $\begin{array}{c}\text { High-High } \\
(4) \\
\end{array}$ & $\begin{array}{c}\text { High-Low } \\
(5) \\
\end{array}$ & $\begin{array}{c}\text { Low-Low } \\
(6)\end{array}$ \\
\hline Neighbor at war ${ }^{a}$ & $\begin{array}{c}-0.031^{* * *} \\
(0.01)\end{array}$ & $\begin{array}{l}-0.011 \\
(0.01)\end{array}$ & $\begin{array}{c}-0.035^{\star * *} \\
(0.01)\end{array}$ & $\begin{array}{c}-0.043^{\star * *} \\
(0.01)\end{array}$ & $\begin{array}{c}-0.032^{* * *} \\
(0.01)\end{array}$ & $\begin{array}{c}-0.032^{* *} \\
(0.02)\end{array}$ \\
\hline Years neighbor at war ${ }^{\mathrm{b}}$ & $\begin{array}{c}-0.014^{* * *} \\
(0.00)\end{array}$ & $\begin{array}{c}-0.017^{* * *} \\
(0.01)\end{array}$ & $\begin{array}{c}-0.012^{\star * *} \\
(0.00)\end{array}$ & $\begin{array}{l}0.006 \\
(0.00)\end{array}$ & $\begin{array}{c}-0.014^{* * *} \\
(0.00)\end{array}$ & $\begin{array}{c}-0.012^{* *} \\
(0.01)\end{array}$ \\
\hline (Years neighbor at war) $^{2}$ & $\begin{array}{c}0.0003^{* * *} \\
(0.00)\end{array}$ & $\begin{array}{l}0.000 \\
(0.00)\end{array}$ & $\begin{array}{c}0.0003^{* * *} \\
(0.00)\end{array}$ & $\begin{array}{c}-0.0003^{\star *} \\
(0.00)\end{array}$ & $\begin{array}{c}0.0003^{\star * \star} \\
(0.00)\end{array}$ & $\begin{array}{l}0.000 \\
(0.00)\end{array}$ \\
\hline War & $\begin{array}{c}-0.044^{\star \star \star} \\
(0.00)\end{array}$ & $\begin{array}{c}-0.043^{\star * *} \\
(0.00)\end{array}$ & $\begin{array}{c}-0.043^{* * *} \\
(0.00)\end{array}$ & $\begin{array}{c}-0.041^{* * *} \\
(0.01)\end{array}$ & $\begin{array}{c}-0.040^{* * *} \\
(0.01)\end{array}$ & $\begin{array}{r}-0.014 \\
(0.01)\end{array}$ \\
\hline Neighbor polity index & $\begin{array}{c}0.006^{\star * *} \\
(0.00)\end{array}$ & $\begin{array}{l}0.003^{*} \\
(0.00)\end{array}$ & $\begin{array}{c}0.005^{\star * *} \\
(0.00)\end{array}$ & $\begin{array}{c}0.014^{* * *} \\
(0.00)\end{array}$ & $\begin{array}{c}0.006^{\star *} \\
(0.00)\end{array}$ & $\begin{array}{r}-0.006 \\
(0.00)\end{array}$ \\
\hline Lrgdppc & $\begin{array}{c}0.331^{* * *} \\
(0.06)\end{array}$ & $\begin{array}{c}0.403^{* * *} \\
(0.05)\end{array}$ & $\begin{array}{c}0.325^{\star \star *} \\
(0.06)\end{array}$ & $\begin{array}{c}0.490^{* * *} \\
(0.08)\end{array}$ & $\begin{array}{c}0.806^{* * *} \\
(0.10)\end{array}$ & $\begin{array}{c}0.620^{* * *} \\
(0.23)\end{array}$ \\
\hline Lrgdppc & $\begin{array}{c}-0.148^{* * *} \\
(0.06)\end{array}$ & $\begin{array}{c}-0.214^{* * *} \\
(0.05)\end{array}$ & $\begin{array}{c}-0.144^{\star * *} \\
(0.05)\end{array}$ & $\begin{array}{c}-0.413^{\star * *} \\
(0.08)\end{array}$ & $\begin{array}{c}-0.493^{* * *} \\
(0.10)\end{array}$ & $\begin{array}{l}0.158 \\
(0.21)\end{array}$ \\
\hline $\mathrm{CU}$ & $\begin{array}{c}0.377^{\star * *} \\
(0.10)\end{array}$ & $\begin{array}{c}0.360^{* * *} \\
(0.10)\end{array}$ & $\begin{array}{c}0.386^{\star * *} \\
(0.10)\end{array}$ & $\begin{array}{c}0.226^{\star * *} \\
(0.07)\end{array}$ & $\begin{array}{c}0.928^{* * *} \\
(0.20)\end{array}$ & $\begin{array}{l}0.011 \\
(0.26)\end{array}$ \\
\hline FTA & $\begin{array}{c}0.326^{* * *} \\
(0.06)\end{array}$ & $\begin{array}{c}0.279 * * * \\
(0.07)\end{array}$ & $\begin{array}{c}0.327^{\star \star *} \\
(0.06)\end{array}$ & $\begin{array}{c}0.387^{\star * *} \\
(0.04)\end{array}$ & $\begin{array}{c}0.647^{* * *} \\
(0.22)\end{array}$ & $\begin{array}{c}0.437^{* * *} \\
(0.15)\end{array}$ \\
\hline Curcol & $\begin{array}{c}-2.810^{* * *} \\
(0.03)\end{array}$ & $\begin{array}{c}-2.688^{* * *} \\
(0.03)\end{array}$ & $\begin{array}{c}-2.811^{\star * *} \\
(0.03)\end{array}$ & & $\begin{array}{c}-3.018^{* * *} \\
(0.04)\end{array}$ & \\
\hline Constant & $\begin{array}{l}2.279 \\
(1.93)\end{array}$ & $\begin{array}{l}-0.186 \\
(1.86)\end{array}$ & $\begin{array}{l}2.454 \\
(1.92)\end{array}$ & $\begin{array}{l}1.108 \\
(2.77)\end{array}$ & $\begin{array}{c}-16.130^{\star * *} \\
(3.49)\end{array}$ & $\begin{array}{c}-16.680^{* *} \\
(8.27)\end{array}$ \\
\hline Observations & 199,912 & 199,912 & 199,912 & 53,963 & 106,528 & 39,421 \\
\hline Number of pairid & 9,024 & 9,024 & 9,024 & 2,039 & 4,718 & 2,267 \\
\hline R2-within & 0.174 & 0.172 & 0.174 & 0.359 & 0.163 & 0.132 \\
\hline R2-between & 0.455 & 0.438 & 0.452 & 0.391 & 0.452 & 0.293 \\
\hline R2-overall & 0.343 & 0.347 & 0.340 & 0.362 & 0.397 & 0.248 \\
\hline $\begin{array}{l}\text { Source: Author's calculation } \\
\text { Robust clustered standard e } \\
{ }^{\star \star *},{ }^{\star *} \text { and }{ }^{*} \text { indicate significe } \\
\text { a Sum of average of neighbo } \\
\text { b Years a dyad has conflict in }\end{array}$ & $\begin{array}{l}\text { parentheses; CPF } \\
\text { the } 1 \%, 5 \% \text { and } 1 \\
\text { magnitude scores } \\
\text { ontiguous state. }\end{array}$ & $\begin{array}{l}\text { time effects included in all } \\
\text { nificance levels, respective } \\
\text { lict for the trading pair. }\end{array}$ & ifications. & & & \\
\hline
\end{tabular}


Table 11. Persistence in regional warfare effects for the world sample, 1948-2006

\begin{tabular}{|c|c|c|c|c|c|c|c|c|c|c|c|c|c|c|c|c|c|c|}
\hline & \multicolumn{6}{|c|}{ Societal conflict } & \multicolumn{6}{|c|}{ International conflict } & \multicolumn{6}{|c|}{ All conflict } \\
\hline & (1) & (2) & (3) & (4) & (5) & (6) & (7) & (8) & (9) & (10) & (11) & (12) & (13) & (14) & (15) & (16) & (17) & (18) \\
\hline Neighbor at war & $\begin{array}{c}-0.043^{* * *} \\
(0.01)\end{array}$ & $\begin{array}{c}*-0.044^{* * *} \\
(0.01)\end{array}$ & $\begin{array}{c}-0.043^{* * *} \\
(0.01)\end{array}$ & $\begin{array}{c}-0.042^{* * *} \\
(0.01)\end{array}$ & $\begin{array}{c}-0.042^{* * *} \\
(0.01)\end{array}$ & $\begin{array}{c}-0.041^{* * *} \\
(0.01)\end{array}$ & $\begin{array}{c}-0.056^{\star \star *} \\
(0.01)\end{array}$ & $\begin{array}{c}-0.058^{* * *} \\
(0.01)\end{array}$ & $\begin{array}{c}-0.059^{* * *} \\
(0.01)\end{array}$ & $\begin{array}{c}-0.060^{* * \star} \\
(0.01)\end{array}$ & $\begin{array}{c}-0.061^{* * *} \\
(0.01)\end{array}$ & $\begin{array}{c}-0.060^{* * *} \\
(0.01)\end{array}$ & $\begin{array}{c}-0.045^{* * *} \\
(0.01)\end{array}$ & $\begin{array}{c}-0.045^{* \star *} \\
(0.01)\end{array}$ & $\begin{array}{c}-0.045^{* * *} \\
(0.01)\end{array}$ & $\begin{array}{c}-0.044^{* \star \star} \\
(0.01)\end{array}$ & $\begin{array}{c}{ }^{*}-0.044^{* \star *} \\
(0.01)\end{array}$ & $\begin{array}{c}{ }^{*}-0.044^{* \star *} \\
(0.01)\end{array}$ \\
\hline Neighbor war end (Nwarend $)^{1}$ & $\begin{array}{l}-0.017 \\
(0.02)\end{array}$ & $\begin{array}{r}-0.020 \\
(0.02)\end{array}$ & $\begin{array}{l}-0.019 \\
(0.02)\end{array}$ & $\begin{array}{r}-0.016 \\
(0.02)\end{array}$ & $\begin{array}{l}-0.015 \\
(0.02)\end{array}$ & $\begin{array}{c}-0.013 \\
(0.02)\end{array}$ & $\begin{array}{c}-0.024^{*} \\
(0.01)\end{array}$ & $\begin{array}{c}-0.030^{* *} \\
(0.01)\end{array}$ & $\begin{array}{c}-0.032^{* *} \\
(0.02)\end{array}$ & $\begin{array}{c}-0.033^{* *} \\
(0.02)\end{array}$ & $\begin{array}{c}-0.031^{*} \\
(0.02)\end{array}$ & $\begin{array}{c}-0.0273^{*} \\
(0.02)\end{array}$ & $\begin{array}{c}-0.018 \\
(0.02)\end{array}$ & $\begin{array}{l}-0.021 \\
(0.02)\end{array}$ & $\begin{array}{l}-0.020 \\
(0.02)\end{array}$ & $\begin{array}{l}-0.018 \\
(0.02)\end{array}$ & $\begin{array}{l}-0.016 \\
(0.02)\end{array}$ & $\begin{array}{l}-0.016 \\
(0.02)\end{array}$ \\
\hline L1.Nwarend & & $\begin{array}{l}-0.027 \\
(0.02)\end{array}$ & $\begin{array}{l}-0.025 \\
(0.02)\end{array}$ & $\begin{array}{l}-0.021 \\
(0.02)\end{array}$ & $\begin{array}{l}-0.019 \\
(0.02)\end{array}$ & $\begin{array}{l}-0.018 \\
(0.02)\end{array}$ & & $\begin{array}{c}-0.044^{* * *} \\
(0.01)\end{array}$ & $\begin{array}{c}*-0.047^{* * *} \\
(0.01)\end{array}$ & $\begin{array}{c}{ }^{*}-0.048^{* * \star} \\
(0.02)\end{array}$ & $\begin{array}{c}-0.046^{* * *} \\
(0.02)\end{array}$ & $\begin{array}{c}*-0.043^{* * *} \\
(0.02)\end{array}$ & & $\begin{array}{l}-0.021 \\
(0.02)\end{array}$ & $\begin{array}{l}-0.020 \\
(0.02)\end{array}$ & $\begin{array}{l}-0.018 \\
(0.02)\end{array}$ & $\begin{array}{l}-0.016 \\
(0.02)\end{array}$ & $\begin{array}{l}-0.015 \\
(0.02)\end{array}$ \\
\hline L2.Nwarend & & & $\begin{array}{l}0.016 \\
(0.02)\end{array}$ & $\begin{array}{l}0.022 \\
(0.02)\end{array}$ & $\begin{array}{l}0.024 \\
(0.02)\end{array}$ & $\begin{array}{l}0.025 \\
(0.02)\end{array}$ & & & $\begin{array}{l}-0.020 \\
(0.01)\end{array}$ & $\begin{array}{l}-0.022 \\
(0.01)\end{array}$ & $\begin{array}{l}-0.019 \\
(0.01)\end{array}$ & $\begin{array}{l}-0.016 \\
(0.02)\end{array}$ & & & $\begin{array}{l}0.013 \\
(0.02)\end{array}$ & $\begin{array}{l}0.018 \\
(0.02)\end{array}$ & $\begin{array}{l}0.019 \\
(0.02)\end{array}$ & $\begin{array}{l}0.019 \\
(0.02)\end{array}$ \\
\hline L3.Nwarend & & & & $\begin{array}{c}\mathbf{0 . 0 6 7 ^ { * * * }} \\
(0.02)\end{array}$ & $\begin{array}{c}0.070^{* * *} \\
(0.02)\end{array}$ & $\begin{array}{c}\mathbf{0 . 0 7 3}^{\text {***}} \\
(0.02)\end{array}$ & & & & $\begin{array}{l}-0.013 \\
(0.01)\end{array}$ & $\begin{array}{l}-0.010 \\
(0.01)\end{array}$ & $\begin{array}{l}-0.006 \\
(0.02)\end{array}$ & & & & $\begin{array}{c}\mathbf{0 . 0 5 3}^{\text {***}} \\
(0.02)\end{array}$ & $\begin{array}{c}\mathbf{0 . 0 5 6 ^ { * \star * }} \\
(0.02)\end{array}$ & $\begin{array}{c}0.056^{\star * \star} \\
(0.02)\end{array}$ \\
\hline L4.Nwarend & & & & & $\begin{array}{c}0.046^{* *} \\
(0.02)\end{array}$ & $\begin{array}{c}0.050^{* *} \\
(0.02)\end{array}$ & & & & & $\begin{array}{l}0.015 \\
(0.01)\end{array}$ & $\begin{array}{l}0.020 \\
(0.01)\end{array}$ & & & & & $\begin{array}{c}0.039^{* *} \\
(0.02)\end{array}$ & $\begin{array}{c}0.041^{\text {** }} \\
(0.02)\end{array}$ \\
\hline L5.Nwarend & & & & & & $\begin{array}{c}0.0506^{* * *} \\
(0.02)\end{array}$ & & & & & & $\begin{array}{c}\mathbf{0 . 0 3 0 ^ { * * }} \\
(0.01)\end{array}$ & & & & & & $\begin{array}{l}0.024 \\
(0.02)\end{array}$ \\
\hline War & $\begin{array}{c}-0.041^{* * *} \\
(0.00)\end{array}$ & $\begin{array}{c}{ }^{*}-0.041^{* * *} \\
(0.00)\end{array}$ & $\begin{array}{c}-0.041^{* \star *} \\
(0.00)\end{array}$ & $\begin{array}{c}-0.041^{* * *} \\
(0.00)\end{array}$ & $\begin{array}{c}-0.041^{* * *} \\
(0.00)\end{array}$ & $\begin{array}{c}-0.040^{* * *} \\
(0.00)\end{array}$ & $\begin{array}{c}-0.043^{* \star *} \\
(0.00)\end{array}$ & $\begin{array}{c}-0.043^{* * *} \\
(0.00)\end{array}$ & $\begin{array}{c}* 0.043^{* * *} \\
(0.00)\end{array}$ & $\begin{array}{c}-0.042^{* \star *} \\
(0.00)\end{array}$ & $\begin{array}{c}-0.042^{\star * \star} \\
(0.00)\end{array}$ & $\begin{array}{c}-0.042^{* * *} \\
(0.00)\end{array}$ & $\begin{array}{c}-0.040^{* * *} \\
(0.00)\end{array}$ & $\begin{array}{c}-0.039^{* * *} \\
(0.00)\end{array}$ & $\begin{array}{c}{ }^{*}-0.039^{* * *} \\
(0.00)\end{array}$ & $\begin{array}{c}{ }^{*}-0.039^{* \star \star} \\
(0.00)\end{array}$ & $\begin{array}{c}{ }^{*}-0.039^{* * *} \\
(0.00)\end{array}$ & $\begin{array}{c}{ }^{*}-0.038^{* * *} \\
(0.00)\end{array}$ \\
\hline Neighbor polity index & $\begin{array}{c}0.004^{* *} \\
(0.00)\end{array}$ & $\begin{array}{c}0.004^{* *} \\
(0.00)\end{array}$ & $\begin{array}{c}0.004^{* *} \\
(0.00)\end{array}$ & $\begin{array}{c}0.004^{* *} \\
(0.00)\end{array}$ & $\begin{array}{c}0.004^{* *} \\
(0.00)\end{array}$ & $\begin{array}{l}0.004^{* *} \\
(0.00)\end{array}$ & $\begin{array}{c}0.004^{* *} \\
(0.00)\end{array}$ & $\begin{array}{c}0.004^{* *} \\
(0.00)\end{array}$ & $\begin{array}{c}0.004^{\star *} \\
(0.00)\end{array}$ & $\begin{array}{c}0.004^{* *} \\
(0.00)\end{array}$ & $\begin{array}{c}0.004^{* *} \\
(0.00)\end{array}$ & $\begin{array}{l}0.004^{* *} \\
(0.00)\end{array}$ & $\begin{array}{c}0.004^{* *} \\
(0.00)\end{array}$ & $\begin{array}{c}0.004^{* *} \\
(0.00)\end{array}$ & $\begin{array}{c}0.004^{* *} \\
(0.00)\end{array}$ & $\begin{array}{c}0.004^{* *} \\
(0.00)\end{array}$ & $\begin{array}{c}0.004^{* *} \\
(0.00)\end{array}$ & $\begin{array}{c}0.004^{* *} \\
(0.00)\end{array}$ \\
\hline Lrgdp & $\begin{array}{c}0.369^{\star \star *} \\
(0.05)\end{array}$ & $\begin{array}{c}0.368^{\star \star *} \\
(0.05)\end{array}$ & $\begin{array}{c}0.369^{\star \star *} \\
(0.05)\end{array}$ & $\begin{array}{c}0.375^{\star \star *} \\
(0.05)\end{array}$ & $\begin{array}{c}0.381^{* * *} \\
(0.05)\end{array}$ & $\begin{array}{c}0.388^{\star \star \star} \\
(0.05)\end{array}$ & $\begin{array}{c}0.384^{* \star *} \\
(0.05)\end{array}$ & $\begin{array}{c}0.384^{* \star *} \\
(0.05)\end{array}$ & $\begin{array}{c}0.384^{\star \star *} \\
(0.05)\end{array}$ & $\begin{array}{c}0.388^{\star \star \star} \\
(0.05)\end{array}$ & $\begin{array}{c}0.393^{\star \star *} \\
(0.05)\end{array}$ & $\begin{array}{c}0.401^{\star \star *} \\
(0.05)\end{array}$ & $\begin{array}{c}0.375^{\star \star *} \\
(0.05)\end{array}$ & $\begin{array}{c}0.375^{\star \star *} \\
(0.05)\end{array}$ & $\begin{array}{c}0.375^{\star * *} \\
(0.05)\end{array}$ & $\begin{array}{c}0.381^{* * *} \\
(0.05)\end{array}$ & $\begin{array}{c}0.386^{\star \star \star} \\
(0.05)\end{array}$ & $\begin{array}{c}0.393^{* * *} \\
(0.05)\end{array}$ \\
\hline Lrgdppc & $\begin{array}{c}-0.179^{* * *} \\
(0.05)\end{array}$ & $\begin{array}{c}{ }^{*}-0.178^{* * *} \\
(0.05)\end{array}$ & $\begin{array}{c}-0.179^{* * *} \\
(0.05)\end{array}$ & $\begin{array}{c}-0.178^{* * *} \\
(0.05)\end{array}$ & $\begin{array}{c}-0.175^{\star * *} \\
(0.05)\end{array}$ & $\begin{array}{c}-0.173^{* \star *} \\
(0.05)\end{array}$ & $\begin{array}{c}-0.196^{* * *} \\
(0.05)\end{array}$ & $\begin{array}{c}-0.195^{\star \star *} \\
(0.05)\end{array}$ & $\begin{array}{c}-0.195^{\star * \star} \\
(0.05)\end{array}$ & $\begin{array}{c}{ }^{*}-0.192^{* * *} \\
(0.05)\end{array}$ & $\begin{array}{c}-0.189^{* \star *} \\
(0.05)\end{array}$ & $\begin{array}{c}-0.186^{* \star *} \\
(0.05)\end{array}$ & $\begin{array}{c}-0.186^{* \star *} \\
(0.05)\end{array}$ & $\begin{array}{c}-0.185^{* * *} \\
(0.05)\end{array}$ & $\begin{array}{c}{ }^{*}-0.186^{* * *} \\
(0.05)\end{array}$ & $\begin{array}{c}{ }^{*}-0.184^{* * *} \\
(0.05)\end{array}$ & $\begin{array}{c}{ }^{*}-0.182^{* * *} \\
(0.05)\end{array}$ & $\begin{array}{c}-0.178^{* * *} \\
(0.05)\end{array}$ \\
\hline $\mathrm{CU}$ & $\begin{array}{c}0.360^{\star \star *} \\
(0.10)\end{array}$ & $\begin{array}{c}0.359^{* \star \star} \\
(0.10)\end{array}$ & $\begin{array}{c}0.360^{* \star *} \\
(0.10)\end{array}$ & $\begin{array}{c}0.360^{* * *} \\
(0.10)\end{array}$ & $\begin{array}{c}0.358^{\star \star *} \\
(0.10)\end{array}$ & $\begin{array}{c}0.356^{\star * *} \\
(0.10)\end{array}$ & $\begin{array}{c}0.368^{\star * *} \\
(0.10)\end{array}$ & $\begin{array}{c}0.369^{* \star *} \\
(0.10)\end{array}$ & $\begin{array}{c}0.370^{* * *} \\
(0.10)\end{array}$ & $\begin{array}{c}0.369^{\star \star \star} \\
(0.10)\end{array}$ & $\begin{array}{c}0.367^{* * *} \\
(0.10)\end{array}$ & $\begin{array}{c}0.364^{\star \star *} \\
(0.10)\end{array}$ & $\begin{array}{c}0.362^{\star * *} \\
(0.10)\end{array}$ & $\begin{array}{c}0.361^{* * *} \\
(0.10)\end{array}$ & $\begin{array}{c}0.361^{* * *} \\
(0.10)\end{array}$ & $\begin{array}{c}0.361^{* \star *} \\
(0.10)\end{array}$ & $\begin{array}{c}0.360^{* \star *} \\
(0.10)\end{array}$ & $\begin{array}{c}0.358^{\star * *} \\
(0.10)\end{array}$ \\
\hline Fta & $\begin{array}{c}0.290^{\star \star \star *} \\
(0.07)\end{array}$ & $\begin{array}{c}0.290^{\star \star *} \\
(0.07)\end{array}$ & $\begin{array}{c}0.290^{\star * *} \\
(0.07)\end{array}$ & $\begin{array}{c}0.290^{\star * *} \\
(0.06)\end{array}$ & $\begin{array}{c}0.291^{\star \star *} \\
(0.06)\end{array}$ & $\begin{array}{c}0.291^{\star * *} \\
(0.06)\end{array}$ & $\begin{array}{c}0.288^{\star \star *} \\
(0.07)\end{array}$ & $\begin{array}{c}0.288^{\star \star *} \\
(0.07)\end{array}$ & $\begin{array}{c}0.288^{\star * *} \\
(0.07)\end{array}$ & $\begin{array}{c}0.289^{\star \star *} \\
(0.07)\end{array}$ & $\begin{array}{c}0.289^{\star * *} \\
(0.07)\end{array}$ & $\begin{array}{c}0.290^{\star \star *} \\
(0.07)\end{array}$ & $\begin{array}{c}0.288^{\star \star *} \\
(0.06)\end{array}$ & $\begin{array}{c}0.288^{* \star *} \\
(0.07)\end{array}$ & $\begin{array}{c}0.288^{* \star *} \\
(0.07)\end{array}$ & $\begin{array}{c}0.289^{* * *} \\
(0.06)\end{array}$ & $\begin{array}{c}0.289^{* \star *} \\
(0.06)\end{array}$ & $\begin{array}{c}0.290^{* \star *} \\
(0.06)\end{array}$ \\
\hline Curcol & $\begin{array}{c}-2.739^{* * *} \\
(0.03)\end{array}$ & $\begin{array}{c}{ }^{*}-2.738^{* * *} \\
(0.03)\end{array}$ & $\begin{array}{c}-2.739^{* * *} \\
(0.03)\end{array}$ & $\begin{array}{c}-2.736^{* \star *} \\
(0.03)\end{array}$ & $\begin{array}{c}-2.735^{* * *} \\
(0.03)\end{array}$ & $\begin{array}{c}-2.733^{* \star *} \\
(0.03)\end{array}$ & $\begin{array}{c}-2.710^{* * *} \\
(0.03)\end{array}$ & $\begin{array}{c}-2.711^{* * *} \\
(0.03)\end{array}$ & $\begin{array}{c}* 2.712^{* * *} \\
(0.03)\end{array}$ & $\begin{array}{c}-2.714^{* * *} \\
(0.03)\end{array}$ & $\begin{array}{c}-2.716^{* \star *} \\
(0.03)\end{array}$ & $\begin{array}{c}-2.718^{* * *} \\
(0.03)\end{array}$ & $\begin{array}{c}-2.740^{* * *} \\
(0.03)\end{array}$ & $\begin{array}{c}-2.742^{* * *} \\
(0.03)\end{array}$ & $\begin{array}{c}{ }^{*}-2.741^{* * *} \\
(0.03)\end{array}$ & $\begin{array}{c}{ }^{*}-2.738^{* * *} \\
(0.03)\end{array}$ & $\begin{array}{c}{ }^{*}-2.736^{* \star *} \\
(0.03)\end{array}$ & $\begin{array}{c}-2.737^{* \star *} \\
(0.03)\end{array}$ \\
\hline Constant & $\begin{array}{l}0.957 \\
(1.85)\end{array}$ & $\begin{array}{l}0.973 \\
(1.85)\end{array}$ & $\begin{array}{l}0.955 \\
(1.85)\end{array}$ & $\begin{array}{l}0.637 \\
(1.86)\end{array}$ & $\begin{array}{l}0.315 \\
(1.87)\end{array}$ & $\begin{array}{l}-0.099 \\
(1.89)\end{array}$ & $\begin{array}{l}0.415 \\
(1.85)\end{array}$ & $\begin{array}{l}0.429 \\
(1.86)\end{array}$ & $\begin{array}{l}0.441 \\
(1.86)\end{array}$ & $\begin{array}{l}0.183 \\
(1.87)\end{array}$ & $\begin{array}{r}-0.136 \\
(1.88)\end{array}$ & $\begin{array}{r}-0.566 \\
(1.90)\end{array}$ & $\begin{array}{l}0.782 \\
(1.85)\end{array}$ & $\begin{array}{l}0.790 \\
(1.85)\end{array}$ & $\begin{array}{l}0.775 \\
(1.85)\end{array}$ & $\begin{array}{l}0.469 \\
(1.86)\end{array}$ & $\begin{array}{l}0.147 \\
(1.87)\end{array}$ & $\begin{array}{r}-0.237 \\
(1.89)\end{array}$ \\
\hline Observations & 199,912 & 199,897 & 199,876 & 199,764 & 199,643 & 199,517 & 199,912 & 199,897 & 199,876 & 199,764 & 199,643 & 199,517 & 199,912 & 199,897 & 199,876 & 199,764 & 199,643 & 199,517 \\
\hline Number of pairid & 9,024 & 9,024 & 9,024 & 9,024 & 9,024 & 9,024 & 9,024 & 9,024 & 9,024 & 9,024 & 9,024 & 9,024 & 9,024 & 9,024 & 9,024 & 9,024 & 9,024 & 9,024 \\
\hline R2-within & 0.172 & 0.172 & 0.172 & 0.172 & 0.172 & 0.172 & 0.172 & 0.172 & 0.172 & 0.172 & 0.172 & 0.172 & 0.172 & 0.172 & 0.172 & 0.172 & 0.172 & 0.172 \\
\hline R2-between & 0.450 & 0.450 & 0.450 & 0.458 & 0.467 & 0.478 & 0.442 & 0.442 & 0.443 & 0.451 & 0.460 & 0.471 & 0.448 & 0.448 & 0.448 & 0.456 & 0.465 & 0.476 \\
\hline R2-overall & 0.351 & 0.351 & 0.351 & 0.360 & 0.369 & 0.381 & 0.346 & 0.347 & 0.347 & 0.356 & 0.365 & 0.376 & 0.350 & 0.350 & 0.350 & 0.359 & 0.369 & 0.380 \\
\hline
\end{tabular}


Table 12. Persistence in regional warfare effects for the subsamples, 1948-2006

\begin{tabular}{|c|c|c|c|c|c|c|}
\hline & \multicolumn{3}{|c|}{ High income $^{a}$} & \multicolumn{3}{|c|}{ Low income ${ }^{b}$} \\
\hline & Societal & International & All & Societal & International & All \\
\hline Neighbor at war & $\begin{array}{c}-0.042^{\star * *} \\
0.00\end{array}$ & $\begin{array}{c}-0.057^{\star * *} \\
(0.01)\end{array}$ & $\begin{array}{c}-0.043^{\star * *} \\
0.00\end{array}$ & $\begin{array}{c}-0.036^{\star * *} \\
(0.00)\end{array}$ & $\begin{array}{c}-0.080^{* * *} \\
(0.01)\end{array}$ & $\begin{array}{c}-0.043^{* * *} \\
(0.00)\end{array}$ \\
\hline Neighbor war end (Nwarend) ${ }^{1}$ & $\begin{array}{l}-0.001 \\
(0.02)\end{array}$ & $\begin{array}{c}-0.026^{* * *} \\
(0.01)\end{array}$ & $\begin{array}{l}0.001 \\
(0.02)\end{array}$ & $\begin{array}{l}-0.011 \\
(0.03)\end{array}$ & $\begin{array}{c}-0.035^{\star *} \\
(0.02)\end{array}$ & $\begin{array}{l}-0.021 \\
(0.03)\end{array}$ \\
\hline L1.Nwarend & $\begin{array}{l}0.007 \\
(0.02)\end{array}$ & $\begin{array}{c}-0.046^{* * *} \\
(0.01)\end{array}$ & $\begin{array}{l}0.014 \\
(0.02)\end{array}$ & $\begin{array}{c}-0.046^{* * *} \\
(0.03)\end{array}$ & $\begin{array}{c}-0.044^{* *} \\
(0.02)\end{array}$ & $\begin{array}{c}-0.051^{* * *} \\
(0.03)\end{array}$ \\
\hline L2.Nwarend & $\begin{array}{c}0.040^{* *} \\
(0.02)\end{array}$ & $\begin{array}{l}-0.011 \\
(0.01)\end{array}$ & $\begin{array}{c}0.045^{\star *} \\
(0.02)\end{array}$ & $\begin{array}{l}0.015 \\
(0.03)\end{array}$ & $\begin{array}{l}-0.021 \\
(0.02)\end{array}$ & $\begin{array}{l}-0.003 \\
(0.03)\end{array}$ \\
\hline L3.Nwarend & $\begin{array}{c}\mathbf{0 . 0 7 1} \mathbf{1}^{* * *} \\
(0.02)\end{array}$ & $\begin{array}{l}-0.008 \\
(0.01)\end{array}$ & $\begin{array}{c}\mathbf{0 . 0 6 2}^{\star * *} \\
(0.02)\end{array}$ & 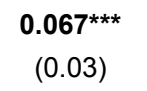 & $\begin{array}{l}-0.006 \\
(0.02)\end{array}$ & $\begin{array}{c}\mathbf{0 . 0 4 2} \\
(0.03)\end{array}$ \\
\hline L4.Nwarend & & $\begin{array}{l}\mathbf{0 . 0 2 4}^{*} \\
(0.01)\end{array}$ & & & $\begin{array}{l}0.026 \\
(0.02)\end{array}$ & \\
\hline L5.Nwarend & & $\begin{array}{l}0.024^{*} \\
(0.01)\end{array}$ & & & $\begin{array}{c}\mathbf{0 . 0 3 6 * *} \\
(0.02)\end{array}$ & \\
\hline War & $\begin{array}{c}-0.040^{* * *} \\
(0.00)\end{array}$ & $\begin{array}{c}-0.040^{* * *} \\
(0.00)\end{array}$ & $\begin{array}{c}-0.038^{* * *} \\
(0.00)\end{array}$ & $\begin{array}{c}-0.034^{* * *} \\
(0.00)\end{array}$ & $\begin{array}{c}-0.033^{* * *} \\
(0.00)\end{array}$ & $\begin{array}{c}-0.032^{\star * *} \\
(0.00)\end{array}$ \\
\hline Neighbor polity index & $\begin{array}{c}0.007^{* * *} \\
(0.00)\end{array}$ & $\begin{array}{c}0.006^{* * *} \\
(0.00)\end{array}$ & $\begin{array}{c}0.006^{\star * *} \\
(0.00)\end{array}$ & $\begin{array}{l}0.001 \\
(0.00)\end{array}$ & $\begin{array}{l}0.001 \\
(0.00)\end{array}$ & $\begin{array}{c}0.001^{* *} \\
(0.00)\end{array}$ \\
\hline Lrgdp & $\begin{array}{c}0.498^{\star * *} \\
(0.02)\end{array}$ & $\begin{array}{c}0.527^{\star \star \star} \\
(0.02)\end{array}$ & $\begin{array}{c}0.503^{* * *} \\
(0.02)\end{array}$ & $\begin{array}{c}0.697^{* * *} \\
(0.03)\end{array}$ & $\begin{array}{c}0.740^{\star \star *} \\
(0.03)\end{array}$ & $\begin{array}{c}0.701^{* * *} \\
(0.03)\end{array}$ \\
\hline Lrgdppc & $\begin{array}{c}-0.327^{* * *} \\
(0.02)\end{array}$ & $\begin{array}{c}-0.341^{* * *} \\
(0.02)\end{array}$ & $\begin{array}{c}-0.333^{* * *} \\
(0.02)\end{array}$ & $\begin{array}{c}-0.294^{\star * *} \\
(0.03)\end{array}$ & $\begin{array}{c}-0.304^{* * *} \\
(0.03)\end{array}$ & $\begin{array}{c}-0.299^{* * *} \\
(0.03)\end{array}$ \\
\hline $\mathrm{CU}$ & $\begin{array}{c}0.469^{* * *} \\
(0.06)\end{array}$ & $\begin{array}{c}0.467^{* * *} \\
(0.06)\end{array}$ & $\begin{array}{c}0.469^{* * *} \\
(0.06)\end{array}$ & $\begin{array}{l}0.338 \\
(0.09)\end{array}$ & $\begin{array}{c}0.346^{* * *} \\
(0.09)\end{array}$ & $\begin{array}{c}0.338^{* * *} \\
(0.09)\end{array}$ \\
\hline Fta & $\begin{array}{c}0.290^{* * *} \\
(0.07)\end{array}$ & $\begin{array}{c}0.480^{* * *} \\
(0.03)\end{array}$ & $\begin{array}{c}0.479^{* * *} \\
(0.03)\end{array}$ & $\begin{array}{c}0.199^{* * *} \\
(0.05)\end{array}$ & $\begin{array}{c}0.200^{* * *} \\
(0.05)\end{array}$ & $\begin{array}{c}0.194^{* * *} \\
(0.05)\end{array}$ \\
\hline Curcol & $\begin{array}{c}-2.740^{\star \star *} \\
(0.40)\end{array}$ & $\begin{array}{c}-2.713^{\star * *} \\
(0.40)\end{array}$ & $\begin{array}{c}-2.739^{\star * *} \\
(0.40)\end{array}$ & $\begin{array}{c}-2.855^{\star *} \\
(0.47)\end{array}$ & $\begin{array}{c}-2.854^{\star * *} \\
(0.47)\end{array}$ & $\begin{array}{l}-2.866 \\
(0.47)\end{array}$ \\
\hline Constant & $\begin{array}{c}-2.595^{\star * *} \\
(0.68)\end{array}$ & $\begin{array}{l}-3.884 \\
(0.68)\end{array}$ & $\begin{array}{c}-2.742^{\star * *} \\
(0.68)\end{array}$ & $\begin{array}{c}-13.966^{* * *} \\
(0.95)\end{array}$ & $\begin{array}{c}-15.927^{\star \star *} \\
(0.96)\end{array}$ & $\begin{array}{c}-14.074^{* * *} \\
(0.95)\end{array}$ \\
\hline Observations & 160,347 & 160,112 & 160,347 & 145,899 & 145,777 & 145,899 \\
\hline Number of pairid & 6,757 & 6,757 & 6,757 & 6,985 & 6,985 & 6,985 \\
\hline R2-within & 0.198 & 0.197 & 0.198 & 0.143 & 0.143 & 0.143 \\
\hline R2-between & 0.436 & 0.442 & 0.434 & 0.461 & 0.466 & 0.460 \\
\hline R2-overall & 0.372 & 0.382 & 0.370 & 0.396 & 0.401 & 0.395 \\
\hline $\begin{array}{l}\text { Source: Author's calculations. } \\
\text { Robust clustered standard errors in } \\
\text { ***, }{ }^{* *} \text { and }{ }^{*} \text { indicate significance at } \\
\text { a Sample includes bilateral trade bet } \\
\text { b Sample includes bilateral trade bet } \\
{ }^{1} \text { Dummy variable equal to one the } f\end{array}$ & $\begin{array}{l}\text { ntheses; CP } \\
1 \%, 5 \% \text { and } \\
n \text { high incom } \\
n \text { low income } \\
\text { ear after war }\end{array}$ & $\begin{array}{l}\text { and time effe } \\
\% \text { significance } \\
\text { group with the } \\
\text { roup with the r } \\
\text { re ended in the }\end{array}$ & $\begin{array}{l}\text { included in } \\
\text { vels, respecti } \\
\text { st of the worlc } \\
t \text { of the world. } \\
\text { eighborhood. }\end{array}$ & $\begin{array}{l}\text { specificatio } \\
\text { ely. }\end{array}$ & & \\
\hline
\end{tabular}


Figure 1. Conflict in neighboring countries, 1948-2006
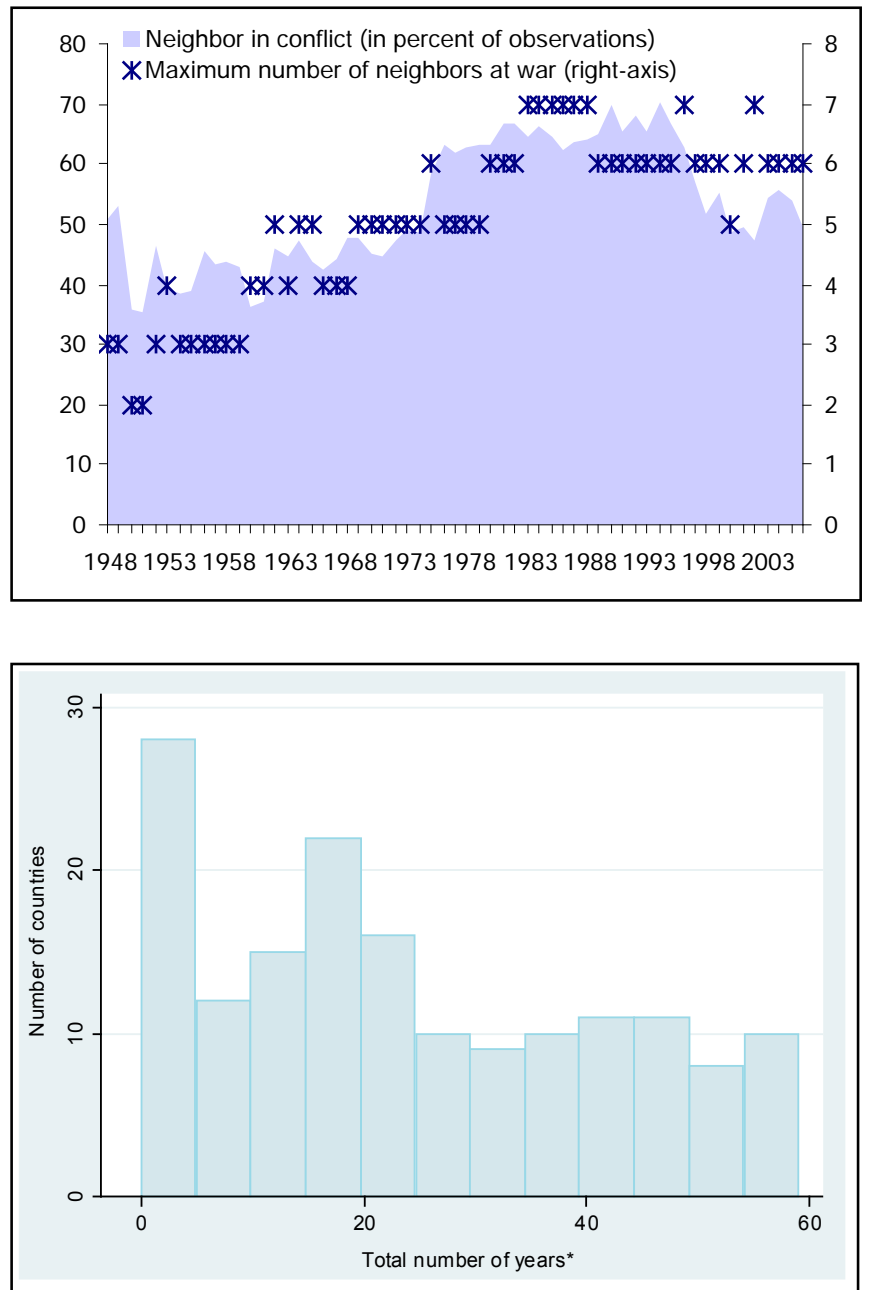

Source: Author's calculations based on CIDCM-CSP MEPV and COW Direct Contiguity databases. *Total number of years a country had conflict in the region during the sample period. 
Figure 2. Societal (intrastate) armed conflict in neighboring states, 1950-2006
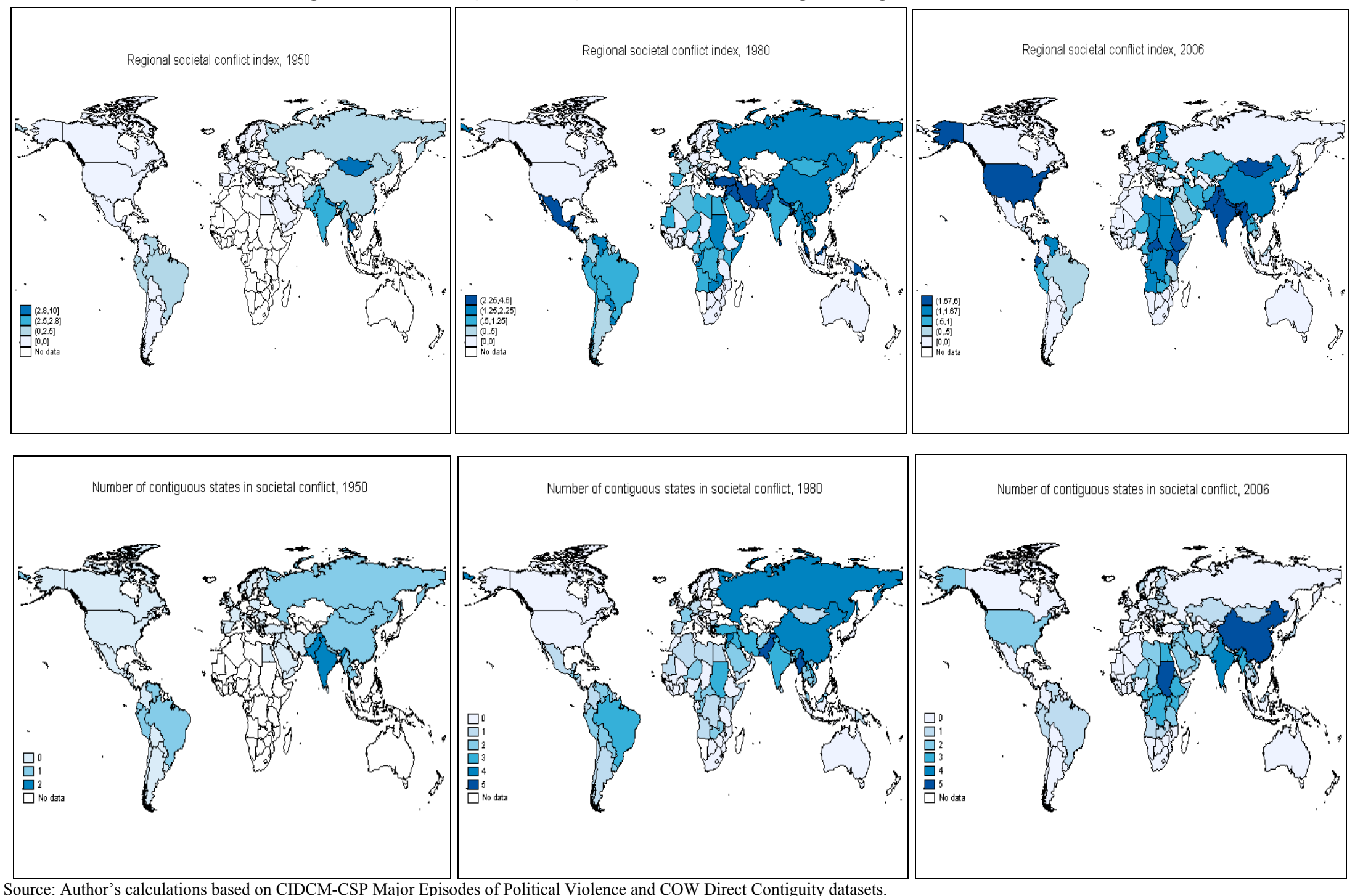
Figure 3. International armed conflict in neighboring states, 1950-2006
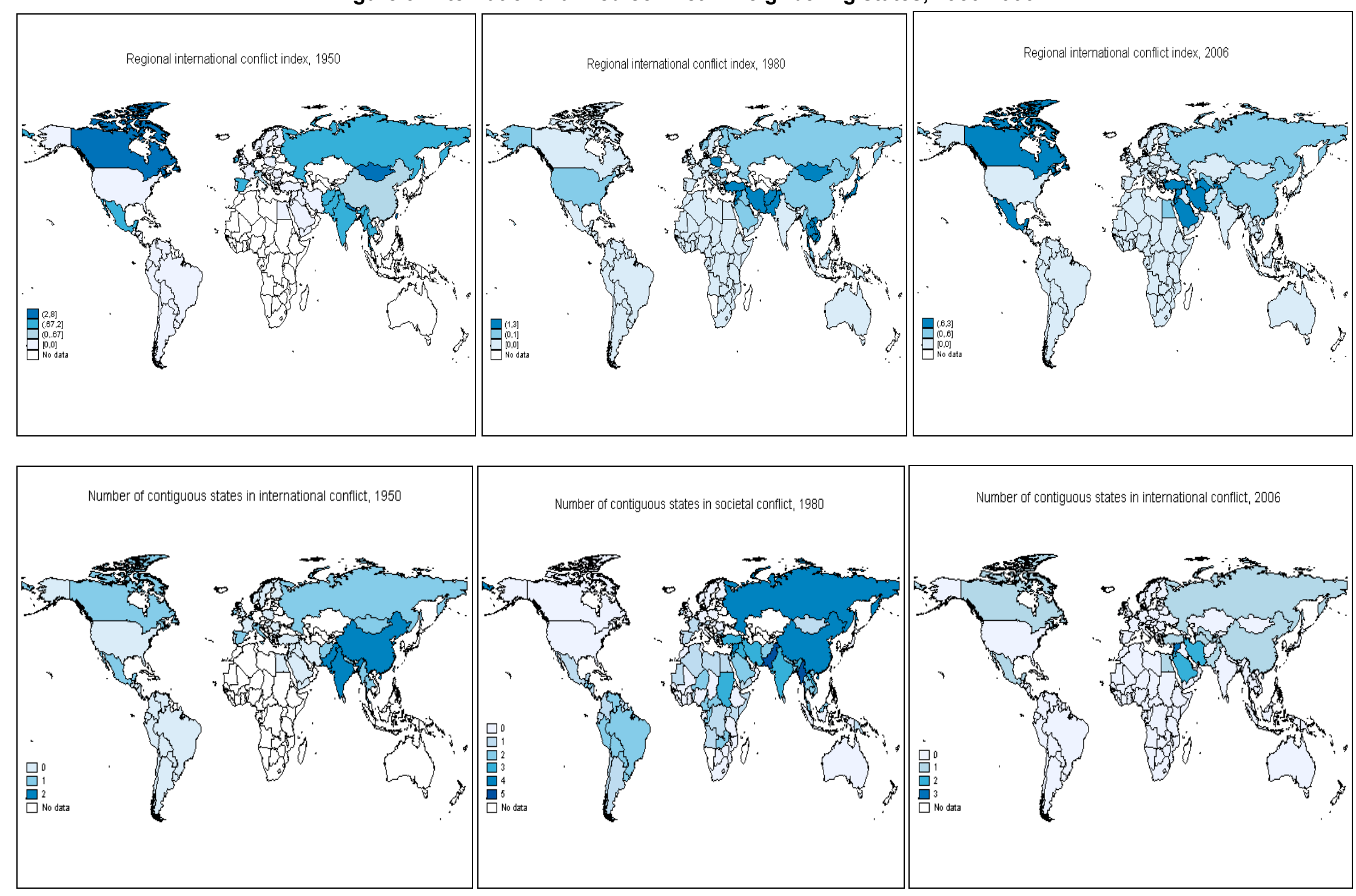

Source: Author's calculations based on CIDCM-CSP Major Episodes of Political Violence and COW Direct Contiguity datasets. 
Figure 4. Conflict and bilateral trade, 1948-2006*
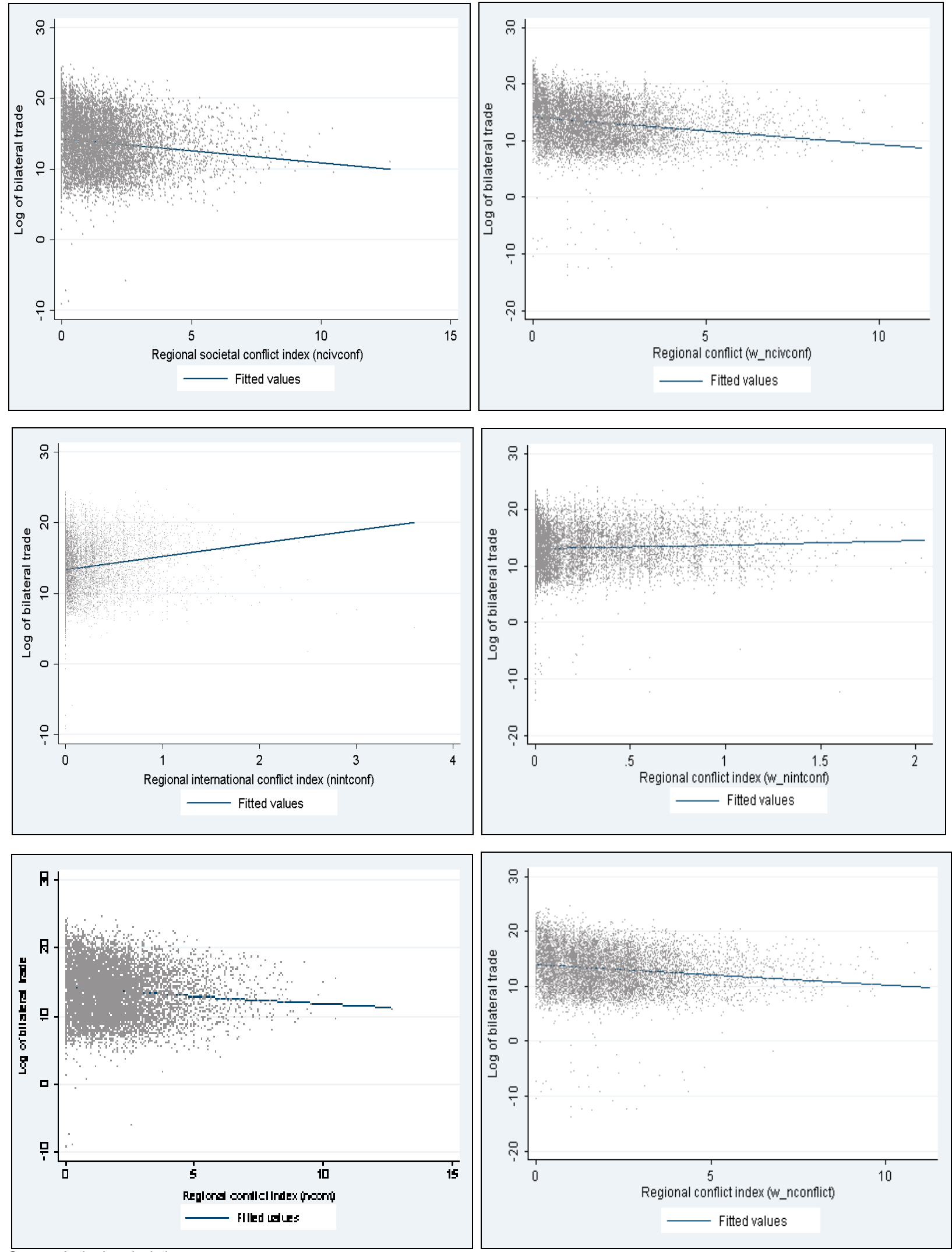

Source: Author's calculations

*Unconditional relationship with the period average of conflict measures and log of bilateral trade for all dyads in the sample. 
Figure 5. Regional conflict and trade (in percent)*

(i) Societal conflict intensity

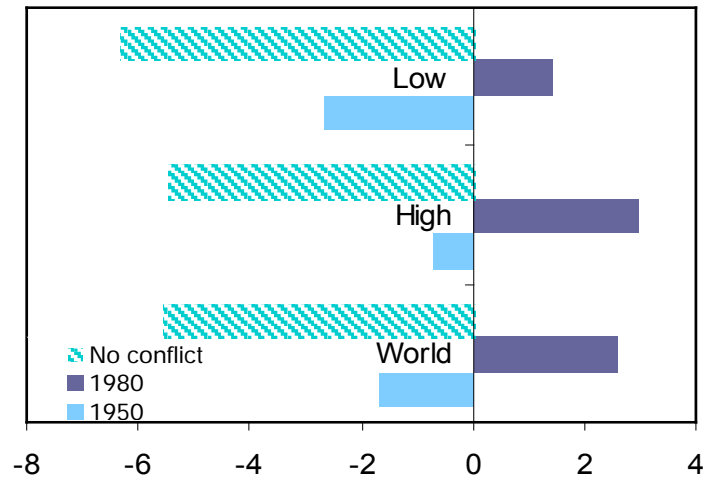

(iii) Societal conflict presence

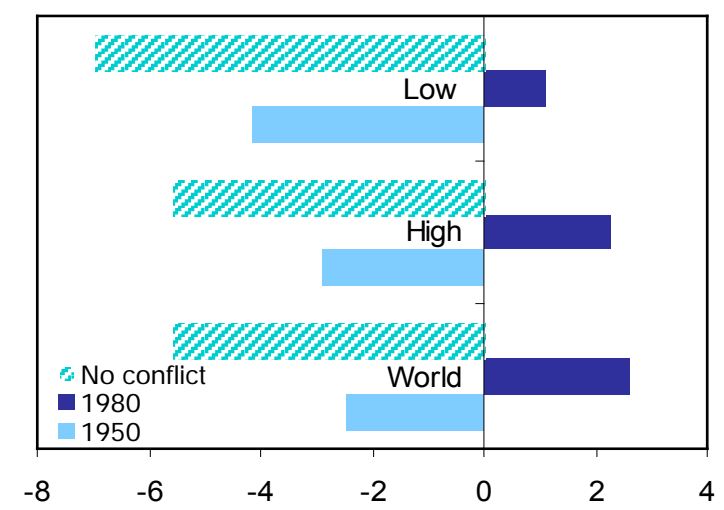

(ii) International conflict intensity

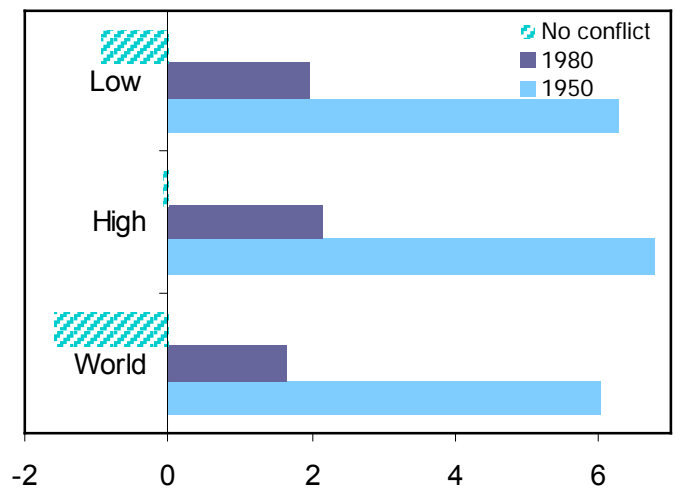

(ii) International conflict presence

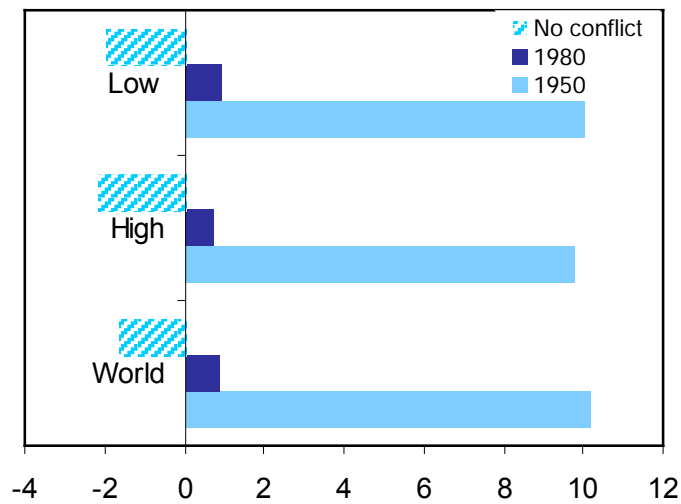

Source: Author's calculations 
Figure 6: Impact of regional conflicts on bilateral trade, 1948-2006
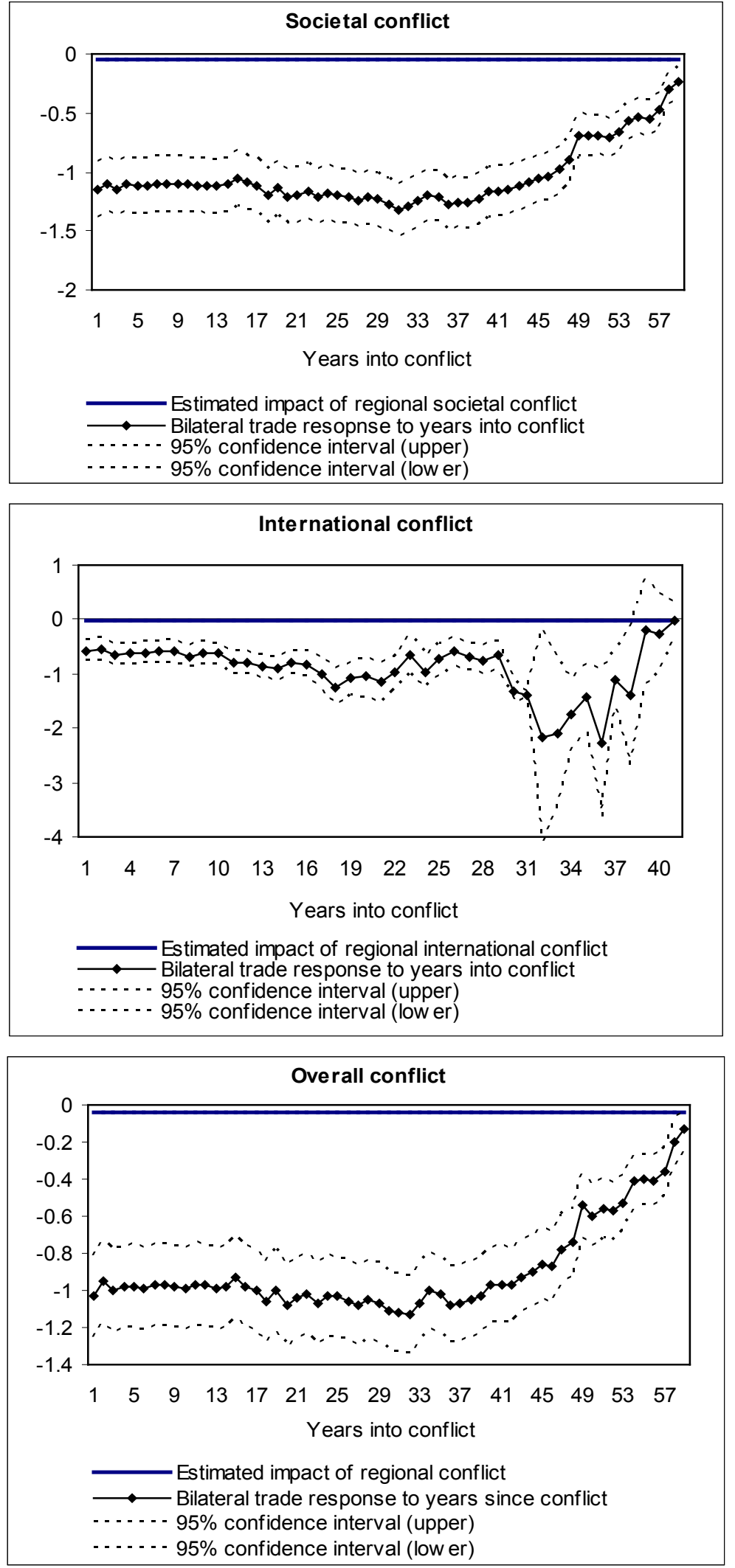

Source: Author's calculations. 


\section{ApPendiX A}

\section{Table A1. Variable definitions and data sources}

\begin{tabular}{|c|c|c|}
\hline Variable & Description & Source \\
\hline \multicolumn{3}{|l|}{ Dependent variable } \\
\hline Irtrade $_{i j t}$ & $\begin{array}{l}\text { Log of the average value of real bilateral } \\
\text { trade between } i \text { and } j \text { at time } t\end{array}$ & $\begin{array}{l}\text { IMF's Direction of Trade }(D o T) \text {; Average of exports from } a \text { to } b \text {, } \\
\text { and } b \text { to } a \text {; and import into a from } b \text {, and to } b \text { from a. Deflated } \\
\text { by U.S. CPI for urban consumers. }\end{array}$ \\
\hline \multicolumn{3}{|l|}{ Other variables } \\
\hline $\begin{array}{l}\text { civviol, civwar, } \\
\text { ethviol, ethwar, } \\
\text { intviol, intwar }\end{array}$ & Magnitude scores (1(lowest)-10(highest)) & $\begin{array}{l}\text { Center for Systemic Peace, Major Episodes of Political } \\
\text { Violence, 1946-2008. Online: } \\
\text { http://www.systemicpeace.org/inscr/inscr.htm }\end{array}$ \\
\hline $\operatorname{Lrgdp}_{i j t}$ & $\begin{array}{l}\text { Log of the product of real GDP of } i \text { and } j \text { at } \\
\text { time } t\end{array}$ & World Bank's World Development Indicators (WDI) 2007 \\
\hline $\operatorname{Lrgdp}_{i j t}$ & $\begin{array}{l}\text { Log of the product of real GDP per capita of } \\
i \text { and } j \text { at time } t\end{array}$ & $W D I$ \\
\hline $\mathrm{CU}_{\mathrm{ijt}}$ & $\begin{array}{l}\text { Binary variable which is unity if } i \text { and } j \text { share } \\
\text { currency at time } t\end{array}$ & Tsangarides et al. (2008) \\
\hline $\mathrm{Fta}_{\mathrm{ij}}$ & $\begin{array}{l}\text { Binary variable which is unity if } i \text { and } j \\
\text { belong to the same regional trade } \\
\text { agreement }\end{array}$ & $\begin{array}{l}\text { WTO (Online: } \\
\text { http://rtais.wto.org/UI/PublicMaintainRTAHome.aspx) }\end{array}$ \\
\hline Ldist $_{i j}$ & Log of the distance between $i$ and $j$ & CIA's World Factbook and Rose (2000) \\
\hline Lang $_{\mathrm{ij}}$ & $\begin{array}{l}\text { Binary variable which is unity if } i \text { and } j \text { have } \\
\text { a common language }\end{array}$ & CIA's World Factbook and Rose (2000) \\
\hline Comborder $_{i j}$ & $\begin{array}{l}\text { Binary variable which is unity if } i \text { and } j \text { share } \\
\text { a land border }\end{array}$ & CIA's World Factbook and Rose (2000) \\
\hline Landl & $\begin{array}{l}\text { Number of landlocked countries in the } \\
\text { country-pair }(0,1 \text {, or } 2)\end{array}$ & CIA's World Factbook and Rose (2000) \\
\hline Island & $\begin{array}{l}\text { Number of island nations in the country-pair } \\
(0,1 \text {, or } 2)\end{array}$ & CIA's World Factbook and Rose (2000) \\
\hline Larea $_{i j}$ & Log of product of land area of $i$ and $j$ & WDI and CIA's World Factbook \\
\hline Comcol $_{\mathrm{ij}}$ & $\begin{array}{l}\text { Binary variable which is unity if } i \text { and } j \text { were } \\
\text { colonies after } 1945 \text { with the same colonizer }\end{array}$ & CIA's World Factbook and Rose (2000) \\
\hline Curcol $_{i j}$ & $\begin{array}{l}\text { Binary variable which is unity if } i \text { and } j \text { are } \\
\text { colonies at time } t\end{array}$ & CIA's World Factbook and Rose (2000) \\
\hline Evercol $_{\mathrm{ij}}$ & $\begin{array}{l}\text { Binary variable which is unity if } \mathrm{i} \text { colonized } \mathrm{j} \\
\text { or vice versa }\end{array}$ & CIA's World Factbook and Rose (2000) \\
\hline Comcty $_{i j}$ & $\begin{array}{l}\text { Binary variable which is unity if } i \text { and } j \\
\text { remained part of the same nation during the } \\
\text { sample }\end{array}$ & CIA's World Factbook and Rose (2000) \\
\hline Sambanis civil war & $\begin{array}{l}\text { Binary variable equal to } 1 \text { if } \mathrm{i} \text { or } \mathrm{j} \text { or both } \\
\text { have a neighbor at war }\end{array}$ & Hegre and Sambanis (2006) \\
\hline UCDP conflict & $\begin{array}{l}\text { Binary variable equal to } 1 \text { if } \mathrm{i} \text { or } \mathrm{j} \text { or both } \\
\text { have a neighbor at war }\end{array}$ & $\begin{array}{l}\text { Gleditsch et al. (2002); version } 4 \text { - } 2009 \text { (Online: } \\
\text { http://www.pcr.uu.se/research/UCDP/data_and_publications/dat } \\
\text { asets.htm) }\end{array}$ \\
\hline Border & $\begin{array}{l}\text { Direct contiguity relationship between two } \\
\text { states where } 1=\text { separted by land or river; } \\
\text { and } 2=\text { separated by } 12 \text { miles of water or } \\
\text { less. }\end{array}$ & $\begin{array}{l}\text { Correlates of War Project. Direct Contiguity Data, 1816-2006. } \\
\text { Version 3.1. Online: http://correlatesofwar.org. }\end{array}$ \\
\hline Border length & Border length for each neighbor country & ClA's World Factbook. \\
\hline
\end{tabular}


Table A2. Summary statistics of selected variables for dyadic data

\begin{tabular}{|lccccc|}
\hline Variable & Obs. & Mean & Std. Dev. & Min & Max \\
\hline Lrtrade & 199,912 & 15.09 & 3.59 & -10.25 & 26.16 \\
Regional conflict intensity & & & & & \\
Societal conflict (Ncivconf) & 199,912 & 1.69 & 1.73 & 0.00 & 17.00 \\
International conflict (Nintconf) & 199,912 & 0.23 & 0.60 & 0.00 & 6.60 \\
All conflict (Nconflict) & 199,912 & 1.92 & 1.91 & 0.00 & 17.00 \\
Regional conflict presence & & & & & \\
Societal conflict (Ncivconfd) & 199,912 & 0.47 & 0.41 & 0.00 & 2.00 \\
International conflict (Nintconfd) & 199,912 & 0.08 & 0.20 & 0.00 & 2.00 \\
All conflict (Nconflictd) & 199,912 & 0.52 & 0.43 & 0.00 & 2.00 \\
Border weighted regional conflict intensity & & & & & \\
Societal conflict (w_ncivconf) & 181,405 & 1.71 & 1.90 & 0.00 & 18.73 \\
International conflict (w_nintconf) & 181,405 & 0.22 & 0.60 & 0.00 & 7.00 \\
All conflict (w_nconflict) & 181,405 & 1.93 & 2.07 & 0.00 & 18.73 \\
Border weighted regional conflict presence & & & & & \\
Societal conflict (w_ncivconfd) & 181,405 & 0.46 & 0.42 & 0.00 & 2.00 \\
International conflict (w_nintconfd) & 181,405 & 0.08 & 0.20 & 0.00 & 2.00 \\
All conflict (w_nconflictd) & 181,405 & 0.51 & 0.44 & 0.00 & 2.00 \\
Conflict intensity in trading partners (war) & 199,912 & 1.37 & 2.35 & 0.00 & 22.00 \\
Neighbor median polity index & 199,912 & 2.77 & 10.27 & -20.00 & 20.00 \\
Lrgdp & 199,912 & 48.05 & 2.93 & 37.39 & 87.13 \\
Lrgdppc & 199,912 & 15.38 & 2.34 & 9.10 & 56.45 \\
CU & 199,912 & 0.02 & 0.13 & 0.00 & 1.00 \\
FTA & 199,912 & 0.04 & 0.20 & 0.00 & 1.00 \\
Ldist & 199,912 & 8.10 & 0.80 & 4.30 & 9.42 \\
\hline Source: Author's calculations. & & & & & \\
\hline
\end{tabular}

Table A3. List of countries according to income groups

\begin{tabular}{|c|c|c|c|c|}
\hline \multicolumn{2}{|c|}{ Upper middle and high } & \multicolumn{3}{|c|}{ Low and lower middle } \\
\hline Algeria & Kuwait & Albania & India & Tanzania \\
\hline Argentina & Latvia & Angola & Indonesia & Thailand \\
\hline Australia & Lebanon & Armenia & Iran & Timor-Leste \\
\hline Austria & Libya & Azerbaijan, Rep. of & Iraq & Togo \\
\hline Bahrain, Kingdom of & Lithuania & Bangladesh & Jordan & Tunisia \\
\hline Belarus & Macedonia, FYR & Benin & Kenya & Turkmenistan \\
\hline Bosnia \& Herzegovina & Mexico & Bolivia & Lao People's Dem. Rep & Ukraine \\
\hline Botswana & Montenegro & Burkina Faso & Lesotho & Uzbekistan \\
\hline Brazil & Namibia & Burundi & Liberia & Vietnam \\
\hline Bulgaria & Netherlands & Cambodia & Malawi & Yemen, Repu \\
\hline Canada & Norway & Cameroon & Mali & Zambia \\
\hline Chile & Oman & Central African Rep. & Mauritania & Zimbabwe \\
\hline Colombia & Panama & Chad & Moldova & \\
\hline Costa Rica & Peru & China & Mongolia & \\
\hline Croatia & Poland & Congo, Dem. Rep. of & Morocco & \\
\hline Cyprus & Portugal & Congo, Republic of & Mozambique & \\
\hline Czech Republic & Romania & Côte d'Ivoire & Nepal & \\
\hline Denmark & Russia & Djibouti & Nicaragua & \\
\hline Dominican Republic & Saudi Arabia & Ecuador & Niger & \\
\hline Equatorial Guinea & Singapore & Egypt & Nigeria & \\
\hline Estonia & Slovak Republic & El Salvador & Pakistan & \\
\hline Finland & Slovenia & Eritrea & Papua New Guinea & \\
\hline France & South Africa & Ethiopia & Paraguay & \\
\hline Gabon & Spain & Gambia, The & Rwanda & \\
\hline Germany & Sweden & Georgia & Senegal & \\
\hline Greece & Switzerland & Ghana & Sierra Leone & \\
\hline Hungary & Turkey & Guatemala & Solomon Islands & \\
\hline Ireland & United Arab Emirates & Guinea & Sri Lanka & \\
\hline Israel & United Kingdom & Guinea-Bissau & Sudan & \\
\hline Italy & United States & Guyana & Swaziland & \\
\hline Japan & Uruguay & Haiti & Syrian Arab Republic & \\
\hline Kazakhstan & Venezuela, Rep. Bol. & Honduras & Tajikistan & \\
\hline
\end{tabular}




\section{APPENDIX B}

Table B1. Estimation results with alternate datasets for world sample

\begin{tabular}{|c|c|c|c|c|c|c|c|}
\hline & \multicolumn{2}{|c|}{ Sambanis } & \multicolumn{5}{|c|}{ UCDP } \\
\hline & Civil war $^{1}$ & $\begin{array}{c}\text { No. of neighbors } \\
\text { at war (total) }\end{array}$ & Interstate $^{3}$ & Internal $^{4}$ & $\begin{array}{c}\text { Internationalized } \\
\text { internal }^{5}\end{array}$ & $\begin{array}{l}\text { No. of neighbors } \\
\text { at war (total) }\end{array}$ & $\begin{array}{c}\text { No. of neighbors } \\
\text { at war (avg.) }\end{array}$ \\
\hline & (1) & (2) & (3) & (4) & (5) & (6) & (7) \\
\hline Neighbor at war & $\begin{array}{c}-0.051^{* * *} \\
(0.02)\end{array}$ & $\begin{array}{c}-0.532^{\star * *} \\
(0.01)\end{array}$ & $\begin{array}{c}-0.109^{* * *} \\
(0.02)\end{array}$ & $\begin{array}{r}-0.006 \\
(0.02)\end{array}$ & $\begin{array}{c}-0.151^{* * *} \\
(0.02)\end{array}$ & $\begin{array}{c}-0.038^{* * *} \\
(0.01)\end{array}$ & $\begin{array}{c}-0.117^{* * *} \\
(0.03)\end{array}$ \\
\hline War $^{a}$ & $\begin{array}{c}-0.174^{\star * *} \\
(0.02)\end{array}$ & $\begin{array}{c}-0.166^{* * *} \\
(0.02)\end{array}$ & $\begin{array}{c}-0.122^{* * *} \\
(0.02)\end{array}$ & $\begin{array}{c}-0.125^{\star * *} \\
(0.02)\end{array}$ & $\begin{array}{c}-0.115^{* * *} \\
(0.02)\end{array}$ & $\begin{array}{c}-0.122^{* * *} \\
(0.02)\end{array}$ & $\begin{array}{c}-0.120^{* * *} \\
(0.02)\end{array}$ \\
\hline Neighbor polity index & $\begin{array}{c}0.009^{* * *} \\
(0.00)\end{array}$ & $\begin{array}{c}0.009^{* * *} \\
(0.00)\end{array}$ & $\begin{array}{c}0.004^{* *} \\
(0.00)\end{array}$ & $\begin{array}{c}0.004^{* *} \\
(0.00)\end{array}$ & $\begin{array}{c}0.004^{* *} \\
(0.00)\end{array}$ & $\begin{array}{c}0.004^{* *} \\
(0.00)\end{array}$ & $\begin{array}{c}0.004^{* *} \\
(0.00)\end{array}$ \\
\hline Lrgdp & $\begin{array}{c}0.134^{* *} \\
(0.05)\end{array}$ & $\begin{array}{c}0.176^{\star * *} \\
(0.06)\end{array}$ & $\begin{array}{c}0.365^{\star * *} \\
(0.05)\end{array}$ & $\begin{array}{c}0.363^{* * *} \\
(0.05)\end{array}$ & $\begin{array}{c}0.374^{\star * *} \\
(0.05)\end{array}$ & $\begin{array}{c}0.374^{* * *} \\
(0.05)\end{array}$ & $\begin{array}{c}0.363^{* * *} \\
(0.05)\end{array}$ \\
\hline Lrgdppc & $\begin{array}{l}0.030 \\
(0.05)\end{array}$ & $\begin{array}{l}-0.011 \\
(0.06)\end{array}$ & $\begin{array}{c}-0.170^{* * *} \\
(0.05)\end{array}$ & $\begin{array}{c}-0.168^{* * *} \\
(0.05)\end{array}$ & $\begin{array}{c}-0.180^{* * *} \\
(0.05)\end{array}$ & $\begin{array}{c}-0.180^{* * *} \\
(0.05)\end{array}$ & $\begin{array}{c}-0.168^{* * *} \\
(0.05)\end{array}$ \\
\hline CU & $\begin{array}{c}0.779^{* * *} \\
(0.17)\end{array}$ & $\begin{array}{c}0.786^{\star * *} \\
(0.17)\end{array}$ & $\begin{array}{c}0.361^{* * *} \\
(0.10)\end{array}$ & $\begin{array}{c}0.362^{* * *} \\
(0.10)\end{array}$ & $\begin{array}{c}0.358^{* * *} \\
(0.10)\end{array}$ & $\begin{array}{c}0.362^{\star * *} \\
(0.10)\end{array}$ & $\begin{array}{c}0.356^{* * *} \\
(0.10)\end{array}$ \\
\hline FTA & $\begin{array}{c}0.204^{* * *} \\
(0.07)\end{array}$ & $\begin{array}{c}0.196^{* * *} \\
(0.07)\end{array}$ & $\begin{array}{c}0.288^{\star * *} \\
(0.07)\end{array}$ & $\begin{array}{c}0.289^{* * *} \\
(0.07)\end{array}$ & $\begin{array}{c}0.284^{* * *} \\
(0.07)\end{array}$ & $\begin{array}{c}0.286^{\star * *} \\
(0.07)\end{array}$ & $\begin{array}{c}0.287^{* * *} \\
(0.07)\end{array}$ \\
\hline Curcol & $\begin{array}{c}-3.123^{\star * *} \\
(0.03)\end{array}$ & $\begin{array}{c}-3.124^{\star * *} \\
(0.03)\end{array}$ & $\begin{array}{c}-2.778^{\star * *} \\
(0.03)\end{array}$ & $\begin{array}{c}-2.778^{\star * *} \\
(0.03)\end{array}$ & $\begin{array}{c}-2.805^{\star * *} \\
(0.03)\end{array}$ & $\begin{array}{c}-2.778^{* * *} \\
(0.03)\end{array}$ & $\begin{array}{c}-2.778^{* * *} \\
(0.03)\end{array}$ \\
\hline Constant & $\begin{array}{c}8.492^{\star * *} \\
(1.85)\end{array}$ & $\begin{array}{c}7.147^{\star * *} \\
(1.86)\end{array}$ & $\begin{array}{l}0.928 \\
(1.87)\end{array}$ & $\begin{array}{l}0.995 \\
(1.87)\end{array}$ & $\begin{array}{l}0.644 \\
(1.87)\end{array}$ & $\begin{array}{l}0.672 \\
(1.87)\end{array}$ & $\begin{array}{l}1.016 \\
(1.87)\end{array}$ \\
\hline Observations & 193,914 & 193,914 & 199,912 & 199,912 & 199,912 & 199,912 & 199,912 \\
\hline Number of pairid & 11,314 & 11,314 & 9,024 & 9,024 & 9,024 & 9,024 & 9,024 \\
\hline R2-within & 0.141 & 0.141 & 0.170 & 0.170 & 0.170 & 0.170 & 0.170 \\
\hline R2-between & 0.312 & 0.324 & 0.442 & 0.442 & 0.442 & 0.450 & 0.440 \\
\hline R2-overall & 0.200 & 0.205 & 0.342 & 0.342 & 0.348 & 0.350 & 0.350 \\
\hline $\begin{array}{l}\text { Source: Author's calculati } \\
\text { Dependent variable is log } \\
\text { Robust clustered standard } \\
\text { *** }{ }^{* *} \text { and }{ }^{*} \text { indicate signif } \\
{ }^{a} \text { Dummy variable equal to } \\
{ }^{1} \text { Dummy variable equal to } \\
2 \text { Total number of neighbo } \\
{ }^{3} \text { Dummy variable equal to } \\
{ }^{4} \text { Dummy variable equal to } \\
{ }^{5} \text { Dummy variable equal to } \\
{ }^{6} \text { Total number of neighbo } \\
{ }^{7} \text { Sum of avg. number of } n\end{array}$ & $\begin{array}{l}\text { ons. } \\
\text { of real bilater } \\
\text { errors in par } \\
\text { ficance at the } \\
\text { one if at leas } \\
\text { one if at leas } \\
\text { rs for the trad } \\
\text { one if at leas } \\
\text { one if at leas } \\
\text { one if at leas } \\
\text { rs for the trad } \\
\text { eighbors for } \epsilon\end{array}$ & $\begin{array}{l}\text { al trade. } \\
\text { entheses; country-pai } \\
1 \%, 5 \% \text { and } 10 \% \text { sig } \\
\text { th one country in the t } \\
\text { st one country in the t } \\
\text { ing pair involved in ci } \\
\text { st one country in the t } \\
\text { st one country in the t } \\
\text { st one country in the t } \\
\text { ing pair involved in in } \\
\text { each trading partner in }\end{array}$ & $\begin{array}{l}\text { and time effect } \\
\text { icance levels, } \\
\text { ding pair is inv } \\
\text { ding pair is inv } \\
\text { war (from Heg } \\
\text { ding pair is inv } \\
\text { ding pair is inv } \\
\text { ding pair is inv } \\
\text { state, intrastat } \\
\text { olved in interst }\end{array}$ & $\begin{array}{l}\text { ts included in } \\
\text { respectively. } \\
\text { olved in some } \\
\text { olved in civil } \\
\text { gre and Samb } \\
\text { olved in inters } \\
\text { olved in intras } \\
\text { olved in interr } \\
\text { te or internati } \\
\text { tate, intrastat }\end{array}$ & $\begin{array}{l}\text { all specifications. } \\
\text { e type of conflict. } \\
\text { war (from Hegre and } \\
\text { banis (2006). } \\
\text { state conflict based or } \\
\text { state conflict based or } \\
\text { nationalized intrastate } \\
\text { ionalized intrastate co } \\
\text { e or internationalized }\end{array}$ & $\begin{array}{l}\text { Sambanis (2006). } \\
\text { UCDP. } \\
\text { UCDP. } \\
\text { conflict based on U } \\
\text { flict based on UCD } \\
\text { ntrastate conflict ba }\end{array}$ & JCDP \\
\hline
\end{tabular}


Table B2. Estimation results with alternate proxies, world sample (1948-2006)

\begin{tabular}{|c|c|c|c|c|c|c|c|}
\hline \multirow[b]{2}{*}{$\begin{array}{l}\text { Estimation } \\
\text { Specification }\end{array}$} & \multicolumn{2}{|c|}{ Societal (intrastate) conflict } & \multicolumn{2}{|c|}{ International conflict } & \multicolumn{3}{|c|}{ Overall conflict } \\
\hline & $\begin{array}{c}\text { Ncivtot }^{1} \\
\text { (1) }\end{array}$ & $\begin{array}{c}\text { No. of neighbors }{ }^{5} \\
\text { (2) } \\
\end{array}$ & $\begin{array}{c}\text { Ninttot }^{2} \\
(3) \\
\end{array}$ & $\begin{array}{c}\text { No. of neighbors }{ }^{5} \\
(4) \\
\end{array}$ & $\begin{array}{c}\text { Nactot }^{3} \\
(5) \\
\end{array}$ & $\begin{array}{c}\text { Pctot }^{4} \\
(6) \\
\end{array}$ & $\begin{array}{c}\text { No. of neighbors } \\
\text { (7) } \\
\end{array}$ \\
\hline Neighbor at war & $\begin{array}{c}-0.016^{* * *} \\
(0.00)\end{array}$ & $\begin{array}{c}-0.058^{\star \star \star} \\
(0.01)\end{array}$ & $\begin{array}{c}-0.017^{* * *} \\
(0.00)\end{array}$ & $\begin{array}{c}-0.070^{* * *} \\
(0.01)\end{array}$ & $\begin{array}{c}-0.015^{\star * *} \\
(0.01)\end{array}$ & $\begin{array}{c}-0.059^{* * *} \\
(0.01)\end{array}$ & $\begin{array}{c}-0.065^{\star * *} \\
(0.01)\end{array}$ \\
\hline War & $\begin{array}{c}-0.042^{* * *} \\
(0.01)\end{array}$ & $\begin{array}{c}-0.042^{* \star *} \\
(0.01)\end{array}$ & $\begin{array}{c}-0.042^{* * *} \\
(0.01)\end{array}$ & $\begin{array}{c}-0.041^{* * *} \\
(0.01)\end{array}$ & $\begin{array}{c}-0.039^{* \star *} \\
(0.01)\end{array}$ & $\begin{array}{c}-0.039^{* * *} \\
(0.01)\end{array}$ & $\begin{array}{c}-0.040^{* * *} \\
(0.01)\end{array}$ \\
\hline Neighbor polity index & $\begin{array}{c}0.004^{* *} \\
(0.00)\end{array}$ & $\begin{array}{l}0.004^{\star *} \\
(0.00)\end{array}$ & $\begin{array}{l}0.004^{\star *} \\
(0.00)\end{array}$ & $\begin{array}{l}0.003^{* *} \\
(0.00)\end{array}$ & $\begin{array}{c}0.003^{* *} \\
(0.00)\end{array}$ & $\begin{array}{c}0.004^{\star *} \\
(0.00)\end{array}$ & $\begin{array}{l}0.003^{* *} \\
(0.00)\end{array}$ \\
\hline Lrgdp & $\begin{array}{c}0.384^{\star \star *} \\
(0.05)\end{array}$ & $\begin{array}{l}0.403^{* * *} \\
(0.0533)\end{array}$ & $\begin{array}{c}0.383^{\star \star \star} \\
(0.01)\end{array}$ & $\begin{array}{c}0.382^{* * *} \\
(0.05)\end{array}$ & $\begin{array}{c}0.389^{* * *} \\
(0.05)\end{array}$ & $\begin{array}{c}0.389^{* * *} \\
(0.05)\end{array}$ & $\begin{array}{c}0.416^{* \star *} \\
(0.05)\end{array}$ \\
\hline Lrgdppc & $\begin{array}{c}-0.193^{* * *} \\
(0.05)\end{array}$ & $\begin{array}{c}-0.213^{\star * *} \\
(0.05)\end{array}$ & $\begin{array}{c}-0.194^{* * *} \\
(0.01)\end{array}$ & $\begin{array}{c}-0.194^{* * *} \\
(0.05)\end{array}$ & $\begin{array}{c}-0.199^{* * *} \\
(0.05)\end{array}$ & $\begin{array}{c}-0.200^{\star * *} \\
(0.05)\end{array}$ & $\begin{array}{c}-0.226^{* * *} \\
(0.05)\end{array}$ \\
\hline $\mathrm{CU}$ & $\begin{array}{c}0.373^{* * *} \\
(0.10)\end{array}$ & $\begin{array}{c}0.378^{* * *} \\
(0.10)\end{array}$ & $\begin{array}{c}0.368^{\star * *} \\
(0.10)\end{array}$ & $\begin{array}{c}0.366^{* * *} \\
(0.10)\end{array}$ & $\begin{array}{c}0.375^{* * *} \\
(0.10)\end{array}$ & $\begin{array}{c}0.375^{\star \star *} \\
(0.10)\end{array}$ & $\begin{array}{c}0.378^{* * *} \\
(0.10)\end{array}$ \\
\hline FTA & $\begin{array}{c}0.291^{* * *} \\
(0.07)\end{array}$ & $\begin{array}{c}0.295^{\star * *} \\
(0.06)\end{array}$ & $\begin{array}{c}0.286^{* * *} \\
(0.07)\end{array}$ & $\begin{array}{c}0.283^{* * *} \\
(0.07)\end{array}$ & $\begin{array}{c}0.288^{* * *} \\
(0.06)\end{array}$ & $\begin{array}{c}0.286^{* * *} \\
(0.07)\end{array}$ & $\begin{array}{c}0.290^{* * *} \\
(0.06)\end{array}$ \\
\hline Curcol & $\begin{array}{c}-2.747^{* * *} \\
(0.03)\end{array}$ & $\begin{array}{c}-2.743^{\star \star *} \\
(0.03)\end{array}$ & $\begin{array}{c}-2.705^{\star * *} \\
(0.03)\end{array}$ & $\begin{array}{c}-2.690^{\star * *} \\
(0.03)\end{array}$ & $\begin{array}{c}-2.739^{\star * *} \\
(0.03)\end{array}$ & $\begin{array}{c}-2.721^{* * *} \\
(0.03)\end{array}$ & $\begin{array}{c}-2.724^{\star * *} \\
(0.03)\end{array}$ \\
\hline Constant & $\begin{array}{l}0.458 \\
(1.85)\end{array}$ & $\begin{array}{l}-0.167 \\
(1.85)\end{array}$ & $\begin{array}{l}0.449 \\
(1.85)\end{array}$ & $\begin{array}{l}0.495 \\
(1.85)\end{array}$ & $\begin{array}{l}0.311 \\
(1.85)\end{array}$ & $\begin{array}{l}0.208 \\
(1.85)\end{array}$ & $\begin{array}{l}-0.542 \\
(1.85)\end{array}$ \\
\hline Observations & 199,912 & 199,912 & 199,912 & 199,912 & 199,912 & 199,912 & 199,912 \\
\hline Number of pairid & 9,024 & 9,024 & 9,024 & 9,024 & 9,024 & 9,024 & 9,024 \\
\hline R2-within & 0.170 & 0.173 & 0.170 & 0.172 & 0.173 & 0.170 & 0.173 \\
\hline R2-between & 0.460 & 0.454 & 0.440 & 0.442 & 0.453 & 0.450 & 0.451 \\
\hline R2-overall & 0.360 & 0.363 & 0.350 & 0.346 & 0.357 & 0.350 & 0.363 \\
\hline Hausman test ( $p$-value) & 0.000 & 0.000 & 0.000 & 0.000 & 0.000 & 0.000 & 0.000 \\
\hline 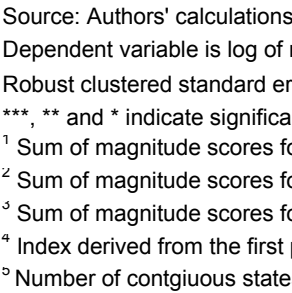 & $\begin{array}{l}\text { bilateral trac } \\
\text { in parenthe } \\
\text { at the } 1 \%, \\
\text { ivil violence, } \\
\text { ternational } \\
\text { ocietal and ir } \\
\text { cipal compo } \\
\text { volved in ea }\end{array}$ & $\begin{array}{l}\text { ses; country-pair and ti } \\
\% \text { and } 10 \% \text { significanc } \\
\text { civil war, ethnic violeno } \\
\text { iolence and war in con } \\
\text { ternational warfare in } \\
\text { ent of the composite s } \\
\text { ch type of conflict. }\end{array}$ & $\begin{array}{l}\text { effects inclu } \\
\text { levels, respec } \\
\text { and ethnic w } \\
\text { uous states. } \\
\text { ntiguous state } \\
\text { cietal and inte }\end{array}$ & $\begin{array}{l}\text { ded in all specification } \\
\text { ctively. } \\
\text { ar in contiguous states } \\
\text { (ncivtot+ninttot). } \\
\text { rnational conflict meas }\end{array}$ & & & \\
\hline
\end{tabular}


Table B3. Estimation results with alternate specifications, world sample (1948-2006)

\begin{tabular}{|c|c|c|c|c|c|c|}
\hline & \multicolumn{6}{|c|}{ Societal conflict } \\
\hline & \multicolumn{3}{|c|}{ Conflict presence (ncivconfd) } & \multicolumn{3}{|c|}{ Conflict intensity (ncivconf) } \\
\hline & $\log \left(X_{i j}\right)^{1}$ & Quadratic $^{2}$ & $\mathrm{PPML}^{3}$ & $\log \left(X_{i j}\right)^{1}$ & Quadratic $^{2}$ & $\mathrm{PPML}^{3}$ \\
\hline \multirow[t]{2}{*}{ Neighbor at war } & $-0.173^{* \star *}$ & $-0.112^{\star \star \star}$ & $-0.233^{* \star *}$ & $-0.047^{* * *}$ & $-0.037^{* \star *}$ & $-0.065^{\star \star *}$ \\
\hline & $(0.02)$ & $(0.02)$ & $(0.04)$ & $(0.01)$ & $(0.01)$ & $(0.01)$ \\
\hline \multirow[t]{2}{*}{ War $^{4}$} & $-0.145^{* \star *}$ & $-0.075^{\star * *}$ & $-0.116^{\star \star *}$ & $-0.041^{* * *}$ & $-0.024^{\star * *}$ & $-0.041^{* * *}$ \\
\hline & $(0.02)$ & $(0.02)$ & $(0.03)$ & $(0.00)$ & $(0.00)$ & $(0.01)$ \\
\hline \multirow[t]{2}{*}{ Neighbor polity score } & $(0.00)$ & $0.007^{\star \star *}$ & $0.013^{* * *}$ & 0.000 & $0.008^{* * *}$ & $0.012^{* * *}$ \\
\hline & $(0.00)$ & $(0.00)$ & $(0.00)$ & $(0.00)$ & $(0.00)$ & $(0.00)$ \\
\hline Observations & 199,912 & 199,912 & 258,469 & 199,912 & 199,912 & 258,469 \\
\hline Number of pairs & 9,024 & 9,024 & 9,024 & 9,024 & 9,024 & 9,024 \\
\hline R2-within & 0.101 & 0.191 & & 0.102 & 0.19 & \\
\hline R2-between & 0.051 & 0.598 & & 0.025 & 0.598 & \\
\hline \multirow[t]{4}{*}{ R2-overall } & 0.050 & 0.536 & & 0.031 & 0.536 & \\
\hline & \multicolumn{6}{|c|}{ International conflict } \\
\hline & \multicolumn{3}{|c|}{ Conflict presence (nintconfd) } & \multicolumn{3}{|c|}{ Conflict intensity (nintconf) } \\
\hline & $\log \left(X_{i j}\right)^{1}$ & Quadratic $^{2}$ & $\mathrm{PPML}^{3}$ & $\log \left(X_{i j}\right)^{1}$ & Quadratic $^{2}$ & $\mathrm{PPML}^{3}$ \\
\hline \multirow[t]{2}{*}{ Neighbor at war } & $-0.210^{\star * \star}$ & $-0.162^{* \star *}$ & 0.044 & $-0.058^{* * *}$ & $-0.044^{* \star *}$ & $0.029^{* *}$ \\
\hline & $(0.03)$ & $(0.03)$ & $(0.04)$ & $(0.01)$ & $(0.01)$ & $(0.01)$ \\
\hline \multirow[t]{2}{*}{ War $^{4}$} & $-0.142^{* * *}$ & $-0.076^{\star * *}$ & $-0.136^{\star * *}$ & $-0.042^{* * *}$ & $-0.025^{\star \star *}$ & $-0.049^{* * *}$ \\
\hline & $(0.02)$ & $(0.02)$ & $(0.03)$ & $(0.00)$ & $(0.00)$ & $(0.01)$ \\
\hline \multirow[t]{2}{*}{ Neighbor polity score } & $(0.00)$ & $0.008^{* * *}$ & $0.007^{* * *}$ & 0.000 & $0.008^{\star * *}$ & $0.007^{\star * *}$ \\
\hline & $(0.00)$ & $(0.00)$ & $(0.00)$ & $(0.00)$ & $(0.00)$ & $(0.00)$ \\
\hline Observations & 199,912 & 199,912 & 258,469 & 199,912 & 199,912 & 258,469 \\
\hline Number of pairs & 9,024 & 9,024 & 9,024 & 9,024 & 9,024 & 9,024 \\
\hline R2-within & 0.100 & 0.191 & & 0.101 & 0.190 & \\
\hline R2-between & 0.041 & 0.597 & & 0.034 & 0.597 & \\
\hline \multirow[t]{4}{*}{ R2-overall } & 0.042 & 0.535 & & 0.037 & 0.535 & \\
\hline & \multicolumn{6}{|c|}{ All conflict } \\
\hline & \multicolumn{3}{|c|}{ Conflict presence (nconfd) } & \multicolumn{3}{|c|}{ Conflict intensity (nconf) } \\
\hline & $\log \left(X_{i j}\right)^{1}$ & Quadratic $^{2}$ & $\mathrm{PPML}^{3}$ & $\log \left(X_{i j}\right)^{1}$ & Quadratic $^{2}$ & $\mathrm{PPML}^{3}$ \\
\hline \multirow[t]{2}{*}{ Neighbor at war } & $-0.182^{* * *}$ & $-0.124^{* * *}$ & $-0.150^{* * *}$ & $-0.048^{* * *}$ & $-0.038^{* * *}$ & $-0.044^{* * *}$ \\
\hline & $(0.02)$ & $(0.02)$ & $(0.04)$ & $(0.01)$ & $(0.01)$ & $(0.01)$ \\
\hline \multirow[t]{2}{*}{ War ${ }^{4}$} & $-0.141^{* * *}$ & $-0.073^{* * *}$ & $-0.109^{* * *}$ & $-0.038^{* * *}$ & $-0.023^{* * *}$ & $-0.041^{* * *}$ \\
\hline & $(0.02)$ & $(0.02)$ & $(0.03)$ & $(0.00)$ & $(0.00)$ & $(0.01)$ \\
\hline \multirow[t]{2}{*}{ Neighbor polity score } & 0.000 & $0.007^{* * *}$ & $0.008^{* * *}$ & 0.000 & $0.008^{* * *}$ & $0.008^{* * *}$ \\
\hline & 0.00 & $(0.00)$ & $(0.00)$ & $(0.00)$ & $(0.00)$ & $(0.00)$ \\
\hline Observations & 199,912 & 199,912 & 258,469 & 199,912 & 199,912 & 258,469 \\
\hline Number of pairs & 9,024 & 9,024 & 9,024 & 9,024 & 9,024 & 9,024 \\
\hline R2-within & 0.101 & 0.191 & & 0.102 & 0.191 & \\
\hline R2-between & 0.057 & 0.597 & & 0.028 & 0.597 & \\
\hline R2-overall & 0.053 & 0.536 & & 0.034 & 0.536 & \\
\hline \multicolumn{7}{|c|}{ 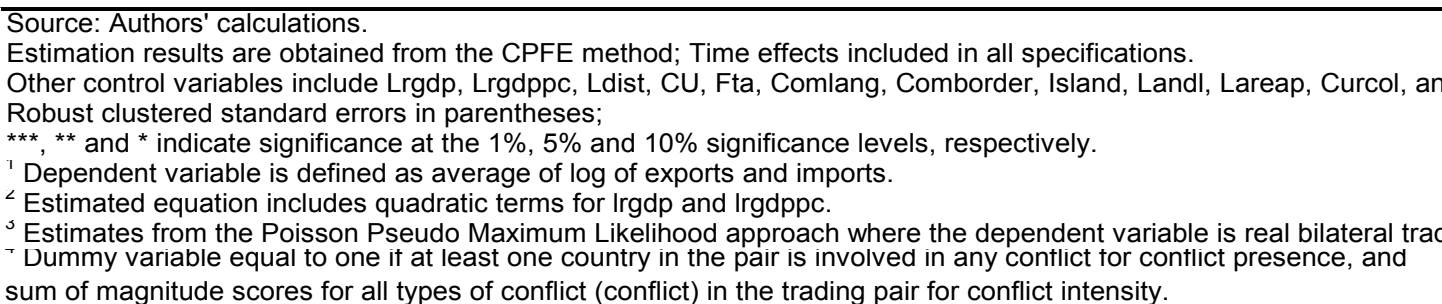 } \\
\hline
\end{tabular}


Table B4. Estimation results with IV approach, 1948-2006

\begin{tabular}{|c|c|c|c|c|c|c|}
\hline \multirow{3}{*}{$\begin{array}{l}\text { Sample } \\
\text { Estimation }\end{array}$} & \multicolumn{6}{|c|}{ All conflict ${ }^{1}$} \\
\hline & \multicolumn{2}{|c|}{ World } & \multicolumn{2}{|c|}{ High } & \multicolumn{2}{|c|}{ Low } \\
\hline & 1 st stage ${ }^{2}$ & 2nd stage ${ }^{3}$ & 1 st stage ${ }^{2}$ & 2nd stage ${ }^{3}$ & 1 st stage ${ }^{2}$ & 2nd stage ${ }^{3}$ \\
\hline Specification & (1) & (2) & (3) & (4) & (5) & (6) \\
\hline \multirow[t]{2}{*}{ Neighbor at war } & $0.060^{* * *}$ & $-0.057^{* * *}$ & $0.053^{* * *}$ & $-0.050^{* * *}$ & $0.053^{* * *}$ & $-0.090^{* * *}$ \\
\hline & $(0.00)$ & $(0.02)$ & $(0.00)$ & $(0.02)$ & $(0.01)$ & $(0.02)$ \\
\hline \multirow[t]{2}{*}{$\mathrm{War}^{\mathrm{a}}$} & & $-0.496^{\star * *}$ & & $-0.505^{\star * *}$ & & $-0.430^{\star * *}$ \\
\hline & & $(0.14)$ & & $(0.14)$ & & $(0.18)$ \\
\hline \multirow[t]{2}{*}{ Milpers } & $0.018^{* * *}$ & & $0.017^{* * *}$ & & $0.018^{* * *}$ & \\
\hline & $(0.00)$ & & $(0.00)$ & & $(0.00)$ & \\
\hline \multirow[t]{2}{*}{ Lrgdp } & $-0.115^{\star \star \star}$ & $0.972^{* * *}$ & $-0.021^{* * *}$ & $1.001^{* * *}$ & $-0.035^{\star * *}$ & $1.115^{\star \star *}$ \\
\hline & $(0.01)$ & $(0.05)$ & $(0.01)$ & $(0.04)$ & $(0.01)$ & $(0.04)$ \\
\hline \multirow[t]{2}{*}{ Lrgdppc } & $-0.112^{\star \star *}$ & -0.077 & $-0.154^{\star \star \star}$ & -0.062 & $-0.245^{\star \star *}$ & $-0.223^{* * *}$ \\
\hline & $(0.01)$ & $(0.05)$ & $(0.01)$ & $(0.05)$ & $(0.01)$ & $(0.07)$ \\
\hline \multirow[t]{2}{*}{$\mathrm{CU}$} & $0.132^{* * *}$ & 0.118 & $0.120^{* * *}$ & $0.130^{*}$ & $0.438^{* * *}$ & 0.216 \\
\hline & $(0.02)$ & $(0.08)$ & $(0.02)$ & $(0.08)$ & $(0.06)$ & $(0.28)$ \\
\hline \multirow[t]{2}{*}{ FTA } & $0.022^{*}$ & $0.165^{\star * *}$ & 0.013 & $0.223^{* * *}$ & 0.012 & 0.112 \\
\hline & $(0.01)$ & $(0.05)$ & $(0.01)$ & $(0.05)$ & $(0.02)$ & $(0.09)$ \\
\hline \multirow[t]{2}{*}{ Constant } & $6.809^{* * *}$ & $-30.431^{* * *}$ & $2.886^{* * *}$ & $-32.132^{* * *}$ & $4.995^{\star * *}$ & $-35.309^{* * *}$ \\
\hline & $(0.45)$ & $(2.09)$ & $(0.31)$ & $(1.29)$ & $(0.32)$ & (1.69) \\
\hline Observations & 110,879 & 110,879 & 88,795 & 88,795 & 81,242 & 81,242 \\
\hline Number of pairid & 9,059 & 9,059 & 6,882 & 6,882 & 6,913 & 6,913 \\
\hline R2-within & 0.08 & 0.08 & 0.07 & 0.09 & 0.09 & 0.07 \\
\hline R2-between & 0.01 & 0.61 & 0.01 & 0.64 & 0.01 & 0.50 \\
\hline R2-overall & 0.01 & 0.58 & 0.01 & 0.62 & 0.01 & 0.47 \\
\hline F-test ( $p$-value) & 0.00 & & 0.00 & & 0.00 & \\
\hline Sargan-Hansen test (p-value) & 0.17 & & 0.32 & & 0.12 & \\
\hline \multicolumn{7}{|l|}{ Source: Authors' calculations. } \\
\hline \multicolumn{7}{|c|}{ CPFE and time effects included in all specifications. } \\
\hline \multicolumn{7}{|c|}{${ }^{* * *},{ }^{* *}$ and ${ }^{*}$ indicate significance at the $1 \%, 5 \%$ and $10 \%$ significance levels, respectively. } \\
\hline \multicolumn{7}{|c|}{ a Sum of magnitude scores for all types of conflict (conflict) in the trading pair. } \\
\hline \multicolumn{7}{|c|}{${ }^{1}$ Sum of average of neighborhood magnitude scores for all types of conflict ( $n$ conflict) for the trading pair. } \\
\hline \multicolumn{7}{|c|}{${ }^{2}$ First stage IV regression: dependent variable is nconflict for the trading pair. } \\
\hline \multicolumn{7}{|c|}{${ }^{3}$ Second stage IV regression: dependent variable is log of real bilateral trade. } \\
\hline
\end{tabular}


Table B5. Estimation results for different regions, 1948-2006

\begin{tabular}{|c|c|c|c|c|c|c|c|c|c|}
\hline & South Asia & South Asia & South Asia & Latin & Latin & Latin & $\begin{array}{c}\text { Europe \& } \\
\text { Central Asia } \\
\end{array}$ & $\begin{array}{c}\text { Europe \& } \\
\text { Central Asia } \\
\end{array}$ & $\begin{array}{c}\text { Europe \& } \\
\text { Central Asia } \\
\end{array}$ \\
\hline Nconflict $^{1}$ & $\begin{array}{c}-0.056^{\star \star *} \\
(0.02)\end{array}$ & & & $\begin{array}{c}-0.062^{* * *} \\
(0.01)\end{array}$ & & & $\begin{array}{c}-0.032^{* \star \star} \\
(0.01)\end{array}$ & & \\
\hline Ncivconf $^{2}$ & & $\begin{array}{c}-0.066^{\star * *} \\
(0.02)\end{array}$ & & & $\begin{array}{c}-0.058^{* * *} \\
(0.01)\end{array}$ & & & $\begin{array}{l}-0.020^{*} \\
(0.01)\end{array}$ & \\
\hline Nintconf $^{3}$ & & & $\begin{array}{r}-0.026 \\
(0.03)\end{array}$ & & & $\begin{array}{c}-0.091^{* * *} \\
(0.02)\end{array}$ & & & $\begin{array}{c}-0.086^{\star * *} \\
(0.02)\end{array}$ \\
\hline $\operatorname{War}^{a}$ & $\begin{array}{l}0.010 \\
(0.01)\end{array}$ & $\begin{array}{l}0.010 \\
(0.01)\end{array}$ & $\begin{array}{l}0.012 \\
(0.01)\end{array}$ & $\begin{array}{c}-0.029^{* * *} \\
(0.01)\end{array}$ & $\begin{array}{c}-0.031^{* * *} \\
(0.01)\end{array}$ & $\begin{array}{c}-0.034^{* * *} \\
(0.01)\end{array}$ & $\begin{array}{c}-0.037^{* * *} \\
(0.01)\end{array}$ & $\begin{array}{c}-0.039^{* * *} \\
(0.01)\end{array}$ & $\begin{array}{c}-0.037^{* * *} \\
(0.01)\end{array}$ \\
\hline $\begin{array}{l}\text { Neighbor polity } \\
\text { score }\end{array}$ & $\begin{array}{r}-0.004 \\
(0.01)\end{array}$ & $\begin{array}{l}-0.005 \\
(0.01)\end{array}$ & $\begin{array}{l}-0.003 \\
(0.01)\end{array}$ & $\begin{array}{l}0.003 \\
(0.00)\end{array}$ & $\begin{array}{l}0.002 \\
(0.00)\end{array}$ & $\begin{array}{l}0.003 \\
(0.00)\end{array}$ & $\begin{array}{c}0.008^{* * *} \\
(0.00)\end{array}$ & $\begin{array}{c}0.008^{* * *} \\
(0.00)\end{array}$ & $\begin{array}{c}0.008^{* * *} \\
(0.00)\end{array}$ \\
\hline Observations & 18,153 & 18,153 & 18,153 & 55,508 & 55,508 & 55,508 & 88,489 & 88,489 & 88,489 \\
\hline Number of pairid & 699 & 699 & 699 & 2,415 & 2,415 & 2,415 & 3,925 & 3,925 & 3,925 \\
\hline R2-within & 0.232 & 0.232 & 0.229 & 0.145 & 0.145 & 0.144 & 0.177 & 0.177 & 0.177 \\
\hline R2-between & 0.399 & 0.387 & 0.431 & 0.428 & 0.430 & 0.417 & 0.511 & 0.509 & 0.500 \\
\hline $\mathrm{R} 2$-overall & 0.282 & 0.270 & 0.310 & 0.343 & 0.344 & 0.332 & 0.463 & 0.462 & 0.457 \\
\hline & East Asia & East Asia & East Asia & $\begin{array}{c}\text { Sub- } \\
\text { Saharan } \\
\text { Africa }\end{array}$ & $\begin{array}{c}\text { Sub- } \\
\text { Saharan } \\
\text { Africa }\end{array}$ & $\begin{array}{l}\text { Sub- } \\
\text { Saharan } \\
\text { Africa }\end{array}$ & & & \\
\hline Nconflict ${ }^{1}$ & $\begin{array}{c}-0.108^{* * *} \\
(0.01)\end{array}$ & & & $\begin{array}{c}-0.035^{\star * *} \\
(0.01)\end{array}$ & & & & & \\
\hline Ncivconf $^{2}$ & & $\begin{array}{c}-0.109^{* * *} \\
(0.01)\end{array}$ & & & $\begin{array}{c}-0.033^{* *} \\
(0.01)\end{array}$ & & & & \\
\hline Nintconf $^{3}$ & & & $\begin{array}{c}-0.047^{\star * *} \\
(0.02)\end{array}$ & & & $\begin{array}{c}-0.042^{*} \\
(0.02)\end{array}$ & & & \\
\hline $\operatorname{War}^{a}$ & $\begin{array}{c}-0.073^{\star * *} \\
(0.01)\end{array}$ & $\begin{array}{c}-0.075^{\star * *} \\
(0.01)\end{array}$ & $\begin{array}{c}-0.076^{* * *} \\
(0.01)\end{array}$ & $\begin{array}{l}-0.014 \\
(0.01)\end{array}$ & $\begin{array}{c}-0.015^{*} \\
(0.01)\end{array}$ & $\begin{array}{c}-0.014^{*} \\
(0.01)\end{array}$ & & & \\
\hline $\begin{array}{l}\text { Neighbor polity } \\
\text { score }\end{array}$ & $\begin{array}{c}-0.015^{\star * *} \\
(0.00)\end{array}$ & $\begin{array}{c}-0.012^{\star \star \star} \\
(0.00)\end{array}$ & $\begin{array}{c}-0.018^{* * *} \\
(0.01)\end{array}$ & $\begin{array}{c}0.012^{\star * *} \\
(0.00)\end{array}$ & $\begin{array}{c}0.012^{* * *} \\
(0.00)\end{array}$ & $\begin{array}{c}0.012^{\star * *} \\
(0.00)\end{array}$ & & & \\
\hline Observations & 33,553 & 33,553 & 33,553 & 69,983 & 69,983 & 69,983 & & & \\
\hline Number of pairid & 1,479 & 1,479 & 1,479 & 3,485 & 3,485 & 3,485 & & & \\
\hline R2-within & 0.401 & 0.400 & 0.394 & 0.0937 & 0.0936 & 0.0933 & & & \\
\hline R2-between & 0.591 & 0.596 & 0.609 & 0.528 & 0.529 & 0.526 & & & \\
\hline R2-overall & 0.494 & 0.495 & 0.533 & 0.456 & 0.456 & 0.454 & & & \\
\hline $\begin{array}{l}\text { Source: Authors' cal } \\
\text { Dependent variable } \\
\text { Robust clustered sta } \\
{ }^{* * *} \text {, }{ }^{* *} \text { and }{ }^{*} \text { indicate } \\
\text { Other control varia } \\
{ }^{a} \text { Sum of magnitude } \\
\text { ' Sum of average of } \\
{ }^{2} \text { Sum of average of } \\
{ }^{3} \text { Sum of average of }\end{array}$ & $\begin{array}{l}\text { Ulations. } \\
\text { s log of real bilc } \\
\text { ddard errors in } \\
\text { significance at } \\
\text { oles include } L \\
\text { scores for all ty } \\
\text { heighborhood } n \\
\text { heighborhood } n \\
\text { heighborhood } n\end{array}$ & $\begin{array}{l}\text { ateral . } \\
\text { parentheses; } \\
\text { the } 1 \%, 5 \% \text { an } \\
\text { rgdp, Lrgdpp } \\
\text { pes of conflict } \\
\text { nagnitude sco } \\
\text { nagnitude sco } \\
\text { nagnitude sco }\end{array}$ & $\begin{array}{l}\text { country-pair an } \\
\text { nd } 10 \% \text { signific } \\
\text { C, Ldist, CU, } \\
\text { in the dyad. } \\
\text { res for civil and } \\
\text { res for internati } \\
\text { res for all types }\end{array}$ & $\begin{array}{l}\text { time effects } \\
\text { nce levels, } r \\
\text { ta, Comlans } \\
\text { ethnic violen } \\
\text { nal violence } \\
\text { of conflict ( } n\end{array}$ & $\begin{array}{l}\text { ncluded in all } \\
\text { spectively. } \\
\text { Comborder } \\
\text { e and war (no } \\
\text { and war (nintc } \\
\text { onflict) for the }\end{array}$ & $\begin{array}{l}\text { specification } \\
\text { Island, Lan } \\
\text { ivconf) for th } \\
\text { onf) for the tr } \\
\text { trading pair. }\end{array}$ & $\begin{array}{l}\text { dl, Lareap, Cur } \\
\text { trading pair. } \\
\text { ading pair. }\end{array}$ & col, and Ever & \\
\hline
\end{tabular}

